\title{
МЕНЕДЖМЕНТ
} ВУЗОВСКИХ

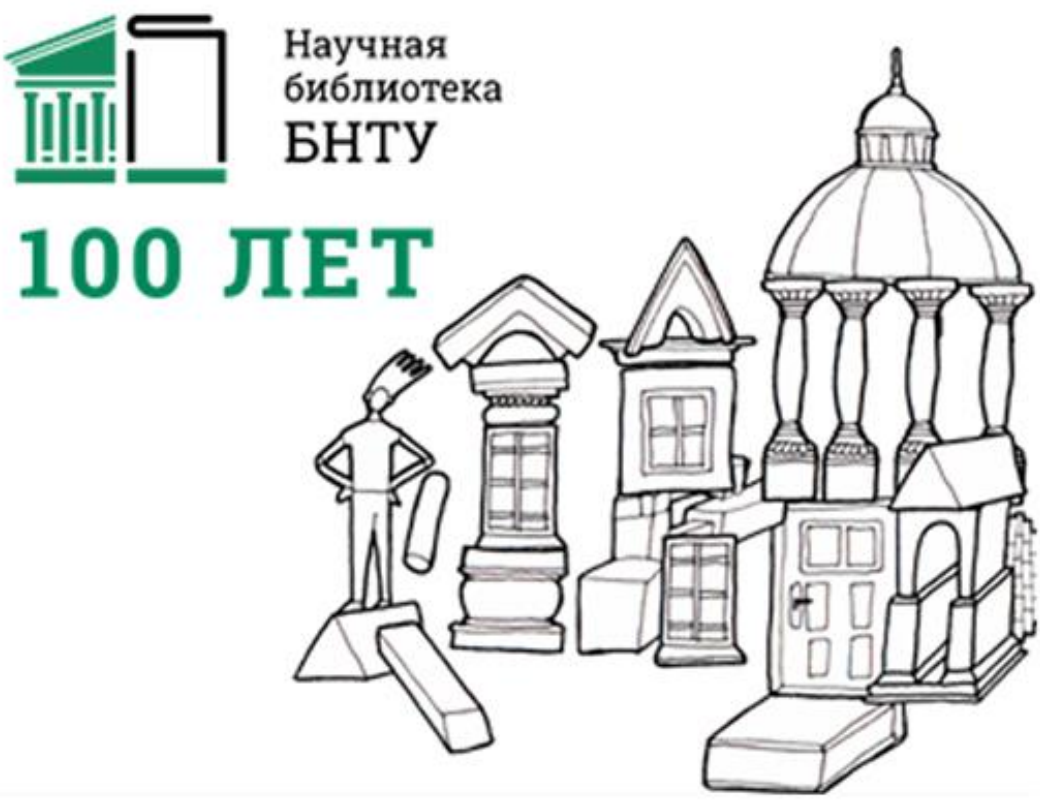
БИБЛИОТЕК

\section{БИБЛИОТЕКА В ЦИФРОВОЙ СРЕДЕ УНИВЕРСИТЕТА: ФОРМИРУЕМ БУДУЩЕЕ СЕГОДНЯ}

Материалы XX Международной научно-практической конференции

Минск, 8-9 декабря 2020 г. 
Министерство образования Республики Беларусь

Белорусский государственный университет

Фундаментальная библиотека

Белорусский национальный технический университет

Научная библиотека

Менеджмент вузовских библиотек.

Библиотека в цифровой среде университета: формируем будущее сегодня

Материалы

XX Международной научно-практической конференции

8-9 декабря 2020 г., Минск 
Решение о депонировании документа принято Советом при директоре Фундаментальной библиотеки Белорусского государственного университета.

Протокол заседания Совета при директоре № 6 от 02.09.2021 г.

\author{
Редакционная коллегия: \\ В.Г. Кулаженко (отв. ред), Е.Н. Садовская
}

\title{
Рецензенты:
}

Политевич Е.Э., доцент кафедры кафедры информационных ресурсов и коммуникаций УО «Белорусский государственный университет культуры и искусств», кандидат педагогических наук, доцент;

Стрелкова И.Б., заведующий кафедрой технологий профессионального образования УО «Республиканский институт профессионального образования», кандидат педагогических наук, доцент.

Менеджмент вузовских библиотек. Библиотека в цифровой среде университета: формируем будущее сегодня : материалы XX Международной научно-практической конференции, 8-9 декабря 2020 г., Минск / Фундаментальная библиотека БГУ, Научная библиотека БНТУ ; [редкол.: В. Г. Кулаженко (отв. ред.), Е. Н. Садовская]. - Минск : БГУ, 2021. - 112 с. : ил. - Библиогр. в конце отд. ст.

Представлены материалы XX Международной научно-практической конференции. Рассматривается роль библиотек в развитии цифровой научной инфраструктуры, формирование информационной и медиа-грамотности, открытая наука и открытый доступ, меры по улучшению показателей университета в мировых рейтинговых системах, услуги и ресурсы для образования, науки и инноваций в условиях пандемии. 


\section{СОДЕРЖАНИЕ}

Кулаженко Владимир Геннадьевич

БЕЗУМНЫЙ 20-Й ГОД. БИБЛИОТЕКИ В НОВЫХХ УСЛОВИЯХ

Лапо Петр Михайлович

О РАБОТЕ БИБЛИОТЕКИ НАЗАРБАЕВ УНИВЕРСИТЕТА

В УСЛОВИЯХ ПАНДЕМИИ

Разумова Ирина Константиновна

БИБЛИОМЕТРИЯ ОТКРЫТОГО ДОСТУПА:

ОСОБЕННОСТИ ЭПОХИ COVID-19

Маслова Анастасия Васильевна

ЛУЧШИЕ ПРАКТИКИ ОБУЧЕНИЯ РАБОТЕ С ДАННЫМИ: ОПЫТ ЗАРУБЕЖНЫХ УНИВЕРСИТЕТСКИХ БИБЛИОТЕК И ЦЕНТРОВ

Гальнский Владимир Михайлович

ДИНАМИКА ПУБЛИКАЦИЙ РЕСПУБЛИКИ БЕЛАРУСЬ В SCOPUS.

КОМПАРАТИВНЫЙ АНАЛИЗ

Ефимов Александр Александрович

DSPАСЕ - ОПЬТ САМОСТОЯТЕЛЬНОГО АУДИТА И ОБНОВЛЕНИЯ

СЕРВИСА С НЕБОЛЬШОЙ ВНЕШНЕЙ ПОДДЕРЖКОЙ

Лопатина Наталья Викторовна

КАДРЫ БИБЛИОТЕКИ СОВРЕМЕННОГО УНИВЕРСИТЕТА:

ОТВЕТИТЬ НА ВЫЗОВЫ ВРЕМЕНИ

Гавдей Анастасия Николаевна

SMM-СПЕЦИАЛИСТ = СОВРЕМЕННЫЙ БИБЛИОТЕКАРЬ

Милюнеи Антонина Чеславовна

КОМПЛЕКТОВАНИЕ БИБЛИОТЕЧНОГО ФОНДА:

ЛОГИСТИЧЕСКИЙ ПОДХОД

Соловьёва Екатерина Васильевна

ФОРМИРОВАНИЕ МЕДИЙНО-ИНФОРМАЦИОННЫХ

КОМПЕТЕНЦИЙ У СТУДЕНТОВ УЧРЕЖДЕНИЙ ВЫСШЕГО

ОБРАЗОВАНИЯ РЕСПУБЛИКИ БЕЛАРУСЬ

МЕЖДУНАРОДНОЙ НАУЧНО-ПРАКТИЧЕСКОЙ КОНФЕРЕНЦИИ «МЕНЕДЖМЕНТ ВУЗОВСКИХ БИБЛИОТЕК» - 20 лет!

ПЕРЕЧЕНЬ международных научно-практических конференций «МЕНЕДЖМЕНТ ВУЗОВСКИХ БИБЛИОТЕК» (2000-2020)

СТРАНИЦЫ ФОТОИСТОРИИ международных научно-практических конференичий «МЕНЕДЖМЕНТ ВУЗОВСКИХ БИБЛИОТЕК» (2000-2020) 


\section{ВИДЕО И ПРЕЗЕНТАЦИИ ДОКЛАДОВ}

\begin{tabular}{|c|c|c|c|}
\hline Название доклада & Спикер & ПРЕЗЕНТАЦИЯ & ВИДЕО \\
\hline \multicolumn{4}{|c|}{$\begin{array}{l}\text { ПАНДЕМИЯ КАК КАТАЛИЗАТОР ГЛОБАЛЬНЫХ ТЕНДЕНЦИЙ: } \\
\text { УГРОЗЫ И ВОЗМОЖНОСТИ ДЛЯ УНИВЕРСИТЕТСКИХ БИБЛИОТЕК }\end{array}$} \\
\hline $\begin{array}{l}\text { Управление } \\
\text { библиотекой в } \\
\text { условиях кризиса: } \\
\text { векторы изменений }\end{array}$ & $\begin{array}{l}\text { Юрик } \\
\text { Инна Викторовна, } \\
\text { директор Научной } \\
\text { библиотеки } \\
\text { БНТУ, } \\
\text { Беларусь, Минск }\end{array}$ & DOI $10.5281 /$ zenodo.4404851 & $\frac{\text { https://youtu.be/ }}{\underline{\text { 0ZJHC2k91lk }}}$ \\
\hline $\begin{array}{l}\text { Проблемы и } \\
\text { практика } \\
\text { университетских } \\
\text { библиотек. } \\
\text { Что изменилось во } \\
\text { время пандемии? }\end{array}$ & $\begin{array}{l}\text { Бруй Оксана } \\
\text { Николаевна, } \\
\text { директор } \\
\text { библиотеки } \\
\text { Национального } \\
\text { технического } \\
\text { университета } \\
\text { Украинь } \\
\text { «Киевский } \\
\text { политехнический } \\
\text { институт», } \\
\text { Украина, Киев }\end{array}$ & DOI $10.5281 /$ zenodo.4404838 & $\frac{\frac{\text { https://youtu.be/ }}{\text { BWMxmgK1ew }}}{\underline{\mathrm{k}}}$ \\
\hline $\begin{array}{l}\text { «Квантовый } \\
\text { прыжок» в новые } \\
\text { правила } \\
\text { социальной } \\
\text { практики: } \\
\text { университетские } \\
\text { библиотеки } \\
\text { Украины }\end{array}$ & $\begin{array}{l}\text { Колесникова } \\
\text { Татьяна } \\
\text { Александровна, } \\
\text { директор Научно- } \\
\text { технической } \\
\text { библиотеки } \\
\text { ДНУЖТ } \\
\text { им. акад. } \\
\text { В. Лазаряна, } \\
\text { Украина, Днепро }\end{array}$ & DOI $10.5281 /$ zenodo.4404792 & $\frac{\text { https://youtu.be/ }}{\underline{\text { oUaBL451tE0 }}}$ \\
\hline $\begin{array}{l}\text { О работе } \\
\text { библиотеки } \\
\text { Назарбаев } \\
\text { Университета в } \\
\text { условиях пандемии }\end{array}$ & $\begin{array}{l}\text { Лапо } \\
\text { Петр Михайлович, } \\
\text { генеральный } \\
\text { эксперт } \\
\text { библиотеки } \\
\text { Назарбаев } \\
\text { Университета, } \\
\text { Казахстан, } \\
\text { Нур-Султан }\end{array}$ & DOI $10.5281 /$ zenodo. 4404781 & $\frac{\text { https://youtu.be/ }}{\text { UP9rHsWFQT0 }}$ \\
\hline
\end{tabular}




\begin{tabular}{|c|c|c|c|}
\hline Название доклада & Спикер & ПРЕЗЕНТАЦИЯ & ВИДЕО \\
\hline $\begin{array}{l}\text { Безумный 20-й год. } \\
\text { Библиотеки в } \\
\text { новых условиях }\end{array}$ & $\begin{array}{l}\text { Кулаженко } \\
\text { Владимир } \\
\text { Геннадьевич, } \\
\text { директор } \\
\text { Фундаментальной } \\
\text { библиотеки БГУ, } \\
\text { Беларусь, Минск }\end{array}$ & DOI $10.5281 /$ zenodo.4404766 & $\frac{\text { https://youtu.be/r }}{\text { jXMofjoMC0 }}$ \\
\hline \multicolumn{4}{|c|}{$\begin{array}{l}\text { ВКЛАД УНИВЕРСИТЕТСКИХ БИБЛИОТЕК } \\
\text { В РАЗВИТИЕ ЦИФРОВОЙ ТРАНСФОРМАЦИИ ОБРАЗОВАНИЯ И НАУКИ }\end{array}$} \\
\hline $\begin{array}{l}\text { Библиотека } \\
\text { в цифровой } \\
\text { экономике, } \\
\text { или экономика } \\
\text { библиотечных } \\
\text { процессов }\end{array}$ & $\begin{array}{l}\text { Курпаков Вадим } \\
\text { Юрьевич, } \\
\text { директор } \\
\text { издательско- } \\
\text { библиотечного } \\
\text { иентра БФУ } \\
\text { им. И. Канта, } \\
\text { Россия, } \\
\text { Калининград }\end{array}$ & DOI $10.5281 /$ zenodo. 4404748 & $\frac{\text { https://youtu.be/ }}{\text { eht2lTVxUVE }}$ \\
\hline $\begin{array}{l}\text { Вузовские } \\
\text { библиотеки в } \\
\text { условиях цифровой } \\
\text { трансформации } \\
\text { и перехода } \\
\text { на дистанционный } \\
\text { формат обучения } \\
\text { и работы }\end{array}$ & $\begin{array}{l}\text { Племнек } \\
\text { Александр } \\
\text { Иванович, } \\
\text { директор } \\
\text { информационно- } \\
\text { библиотечного } \\
\text { комплекса } \\
\text { СПбПУ, } \\
\text { Россия, Санкт- } \\
\text { Петербург }\end{array}$ & DOI $10.5281 /$ zenodo. 4404723 & $\underline{\text { https://youtu.be/ }}$ \\
\hline $\begin{array}{l}\text { Кадры библиотеки } \\
\text { современного } \\
\text { университета: } \\
\text { ответить на } \\
\text { вызовы времени }\end{array}$ & $\begin{array}{l}\text { Лопатина Наталья } \\
\text { Викторовна, } \\
\text { заведующиий } \\
\text { кафедрой } \\
\text { библиотечно- } \\
\text { информационньхх } \\
\text { наук МГИК, } \\
\text { Россия, Москва }\end{array}$ & DOI $10.5281 /$ zenodo .4404681 & $\frac{\text { https://youtu.be/ }}{\text { cf8R88pCLC0 }}$ \\
\hline «Вопросы-ответы» & & & $\frac{\text { https://youtu.be/ }}{\text { xM19Fraro5Q }}$ \\
\hline
\end{tabular}




\begin{tabular}{|c|c|c|c|}
\hline Название доклада & Спикер & ПРЕЗЕНТАЦИЯ & ВИДЕО \\
\hline \multicolumn{4}{|l|}{ СЕССИЯ 3.} \\
\hline \multicolumn{4}{|c|}{$\begin{array}{l}\text { ПРОЕКТНАЯ ДЕЯТЕЛЬНОСТЬ УНИВЕРСИТЕТСКИХ БИБЛИОТЕК: } \\
\text { НОВЫЕ ВОЗМОЖНОСТИ ДЛЯ СОЗДАНИЯ ИННОВАЦИЙ }\end{array}$} \\
\hline $\begin{array}{l}\text { Менеджмент } \\
\text { креативных } \\
\text { проектов в научной } \\
\text { библиотеке } \\
\text { исследовательского } \\
\text { университета: опыт } \\
\text { и перспективы }\end{array}$ & $\begin{array}{l}\text { Сербин Олег } \\
\text { Олегович, } \\
\text { директор Научной } \\
\text { библиотеки им. } \\
\text { М. Максимовича } \\
\text { КНУ им. Тараса } \\
\text { Шевченко, } \\
\text { Украина, Киев } \\
\text { Ситницкий } \\
\text { Максим } \\
\text { Васильевич, } \\
\text { заведующчй } \\
\text { кафедрой } \\
\text { Менеджмента } \\
\text { инновационной и } \\
\text { инвестиционной } \\
\text { деятельности } \\
\text { КНУ им. Тараса } \\
\text { Шевченко, } \\
\text { Украина, Киев }\end{array}$ & DOI $10.5281 /$ zenodo. 4404623 & $\frac{\text { https://youtu.be/ }}{\text { TdC4auVtPsE }}$ \\
\hline \multicolumn{4}{|c|}{$\begin{array}{l}\text { СЕССИЯ } 4 . \\
\text { УНИВЕРСИТЕТСКИЕ БИБЛИОТЕКИ В ЖИЗНЕННОМ ЦИКЛЕ } \\
\text { НАУЧНЫХ ИССЛЕДОВАНИЙ: СТРАТЕГИЧЕСКИЕ НАПРАВЛЕНИЯ, } \\
\text { ОБМЕН ОПЫТОМ И ЛУЧШИМИ ПРАКТИКАМИ }\end{array}$} \\
\hline $\begin{array}{l}\text { Библиометрия } \\
\text { Открытого } \\
\text { доступа. } \\
\text { Особенности эпохи } \\
\text { COVID-19 }\end{array}$ & $\begin{array}{l}\text { Разумова } \\
\text { Ирина } \\
\text { Константиновна, } \\
\text { заместитель } \\
\text { директора, } \\
\text { Национальный } \\
\text { электронно- } \\
\text { информачионный } \\
\text { консорииум } \\
\text { (НЭИКОН), } \\
\text { Россия, } \\
\text { Санкт-Петербург }\end{array}$ & DOI $10.5281 /$ zenodo.4401607 & $\frac{\text { https://youtu.be/ }}{\underline{\text { 0qAz50LOv3g }}}$ \\
\hline
\end{tabular}




\begin{tabular}{|c|c|c|c|c|}
\hline Название доклада & Спикер & & ПРЕЗЕНТАЦИЯ & ВИДЕО \\
\hline $\begin{array}{l}\text { Динамика } \\
\text { публикаций } \\
\text { Республики } \\
\text { Беларусь в Scopus. } \\
\text { Компаративный } \\
\text { анализ }\end{array}$ & $\begin{array}{l}\text { Галынский } \\
\text { Владимир } \\
\text { Михайлович, } \\
\text { заместитель } \\
\text { начальника } \\
\text { Управления } \\
\text { международньх } \\
\text { связей БГУ, } \\
\text { Беларусь, Минск }\end{array}$ & DOI & $10.5281 /$ zenodo. 4401163 & $\frac{\text { https://youtu.be/i }}{\text { 4uFU0pitqI }}$ \\
\hline $\begin{array}{l}\text { Open Ukrainian } \\
\text { Citation Index: } \\
\text { источники данных } \\
\text { и принцип работы }\end{array}$ & $\begin{array}{l}\text { Назаровец Сергей } \\
\text { Андреевич, } \\
\text { заместитель } \\
\text { директора по } \\
\text { научной работе } \\
\text { ГНТБ Украинь, } \\
\text { Украина, Киев }\end{array}$ & DOI & $10.5281 /$ zenodo. 4400873 & $\frac{\frac{\text { https://youtu.be/ }}{\text { QKP7CAcWM }}}{\underline{\mathrm{mI}}}$ \\
\hline $\begin{array}{l}\text { Формирование } \\
\text { и развитие } \\
\text { программно- } \\
\text { модульного } \\
\text { комплекса } \\
\text { поддержки, } \\
\text { анализа } \\
\text { и стимулирования } \\
\text { публикационной } \\
\text { деятельности } \\
\text { преподавателей } \\
\text { и научных } \\
\text { сотрудников } \\
\text { университета } \\
\text { (опыт РГПУ им. } \\
\text { А.И. Герцена, } \\
\text { Санкт-Петербург, } \\
\text { Россия) }\end{array}$ & $\begin{array}{l}\text { Морозова } \\
\text { Светлана } \\
\text { Александровна, } \\
\text { заместитель } \\
\text { директора } \\
\text { Фундаментальной } \\
\text { библиотеки РГПУ } \\
\text { им. А.И. Гериена, } \\
\text { Россия, } \\
\text { Санкт-Петербург }\end{array}$ & DOI & $10.5281 /$ zenodo. 4396173 & $\frac{\text { https://youtu.be/ }}{\underline{\text { OfaFz_TqE6s }}}$ \\
\hline
\end{tabular}




\begin{tabular}{|c|c|c|c|}
\hline Название доклада & Спикер & ПРЕЗЕНТАЦИЯ & ВИДЕО \\
\hline $\begin{array}{l}\text { Инициативы } \\
\text { академических } \\
\text { библиотек } \\
\text { по внедрению } \\
\text { качественных } \\
\text { практик работы с } \\
\text { исследовательским } \\
\text { и данными: } \\
\text { актуальная } \\
\text { повестка }\end{array}$ & $\begin{array}{l}\text { Кокарев } \\
\text { Константин } \\
\text { Павлович, } \\
\text { заведуюший } \\
\text { отделом } \\
\text { поддержки } \\
\text { исследований } \\
\text { Научной } \\
\text { библиотеки } \\
\text { РАНХиГС, } \\
\text { Россия, Москва }\end{array}$ & DOI $10.5281 /$ zenodo. 4396122 & $\frac{\text { https://youtu.be/ }}{\underline{\text { MvjnzXmti9k }}}$ \\
\hline $\begin{array}{l}\text { Лучшие практики } \\
\text { обучения работе } \\
\text { с данными: опыт } \\
\text { зарубежных } \\
\text { университетских } \\
\text { библиотек } \\
\text { и центров }\end{array}$ & $\begin{array}{l}\text { Маслова } \\
\text { Анастасия } \\
\text { Васильевна, } \\
\text { ведуший } \\
\text { библиотекарь } \\
\text { отдела } \\
\text { поддержки } \\
\text { исследований } \\
\text { Научной } \\
\text { библиотеки } \\
\text { РАНХиГС, } \\
\text { Россия, Москва }\end{array}$ & DOI $10.5281 /$ zenodo.4396021 & $\begin{array}{l}\text { https://youtu.be/ } \\
\text { CZKXLvCDojk }\end{array}$ \\
\hline «Вопросы-ответы» & & & $\begin{array}{l}\text { https://youtu.be/ } \\
\underline{\text { 0mUeG45rYZU }}\end{array}$ \\
\hline \multicolumn{4}{|c|}{$\begin{array}{l}\text { СПЕЦИАЛЬНОЕ МЕРОПРИЯТИЕ } \\
\text { ДЛЯ ІТ-СЛУЖБ ПОДДЕРЖКИ ИНСТИТУЦИОНАЛЬНЫХ РЕПОЗИТОРИЕВ }\end{array}$} \\
\hline $\begin{array}{l}\text { Dspace - опыт } \\
\text { самостоятельного } \\
\text { аудита и } \\
\text { обновления сервиса } \\
\text { с небольшой } \\
\text { внешней } \\
\text { поддержкой }\end{array}$ & $\begin{array}{l}\text { Ефимов } \\
\text { Александр } \\
\text { Александрович, } \\
\text { заместитель } \\
\text { начальника } \\
\text { отдела } \\
\text { информационно- } \\
\text { аналитического } \\
\text { сопровождения } \\
\text { УрФУ им. Первого } \\
\text { Президента } \\
\text { России } \\
\text { Б.Н. Ельцина, } \\
\text { Россия, } \\
\text { Екатеринбург }\end{array}$ & DOI $10.5281 /$ zenodo. 4395687 & $\frac{\text { https://youtu.be/ }}{\underline{\text { dfwmHee_Do Do }}}$ \\
\hline
\end{tabular}


DOI: $10.33581 / 2020-20-9-14$

\section{БЕЗУМНЫЙ 20-Й ГОД. БИБЛИОТЕКИ В НОВЫХ УСЛОВИЯХ MAD 20TH YEAR. LIBRARIES IN NEW CONDITIONS}

Кулаженко Владимир Геннадьевич - директор Фундаментальной библиотеки Белорусского государственного университета (Беларусь), e-mail: kulazhanka@bsu.by

Uladzimir G. Kulazhanka - Director of the Fundamental Library of the Belarusian State University (Belarus), e-mail: kulazhanka@bsu.by

Аннотация: Проанализирован характер изменений внешней среды и набор кризисов, переживаемых библиотеками в условиях распространения пандемии. Изучено их влияние на образовательный процесс, персонал, иинформационные ресурсы. Приведень новые подходыл к управлению персоналом и коллекциями вузовских библиотек в условиях коренных изменений.

Abstract: Analyzed the nature of changes in the external environment and a set of crises experienced by libraries in the context of the spread of a pandemic. Studied their influence on the educational process, personnel and information resources. Also presented new approaches to the management of personnel and collections of academic libraries in the context of fundamental changes.

Ключевые слова: открытый доступ, виртуальные библиотечные сервисы, дистанционное обучение, управление изменениями

Keywords: open access, virtual library services, distance learning, change management 
Достаточно широко в экспертном сообществе в последние годы обсуждается место и роль библиотек, находящихся под постоянным давлением смены технологических укладов. Если для всех библиотек, независимо от вида и отраслевой принадлежности, характерна адаптация к общей цифровизации информационных ресурсов и переход части пользователей на электронное чтение, то в университетах (дополнительно к этим процессам) происходит постепенное распространение инновационных форм и методов обучения, а также переход системы научных коммуникаций на цифровую основу.

Однако 2020-й год и глобальное распространение коронавируса COVID-19 привели к смене характера изменений. Первое, это существенное увеличение их скорости и интенсивности. События стали происходить быстрее, чем возникает реакция на них, зачастую они непредсказуемы и не имеют аналогов в прошлом.

Основные угрозы, возникающие в разрыве между возникновением вызова и реакцией, связаны с кризисом обучения. Охватившая профессионалов в сфере образования тревога привела к обсуждению данной проблемы на самом высоком уровне. Так, в опубликованной в августе 2020 года Концептуальной записке Генерального секретаря ООН Антониу Гутерриша «Образование в эпоху пандемии COVID-19 и последующие годы» отмечалось, что «Пандемия привела к самым серьезным нарушениям в системах образования в мире за всю историю и угрожает потерей навыков и знаний, способна охватить не одно поколение обучаемых» [1].

Направленные на противодействие распространению вируса ограничения на традиционные формы обучения обнажили серьезность проблем, связанных как с трансляцией знаний, так и с их восприятием. Другими словами, и преподаватели и студенты оказались не готовы к подобному сдвигу парадигм. 
Определение проблемы и видение ее решения была приведена в совместном заявлении ЮНЕСКО, ЮНИСЕФ Международной организации труда и Международной организации образования, где отмечалось, что «Без неотложных действий и увеличения инвестиций, кризис в обучении может превратиться в образовательную катастрофу» и далее «чтобы создать жизнеспособный преподавательский состав во время кризиса, все преподаватели должны обладать цифровыми и педагогическими навыками для обучения удаленно, онлайн, а также с помощью смешанного или гибридного обучения» [2].

Стоит согласится, что кризис компетенций в образовании сегодня первичен. Возникает и закономерное сопротивление изменениям - игнорируя новые условия. В свою очередь, возникает вопрос о готовности сотрудников университетских библиотек к подобной форсированной цифровизации.

В контексте библиотек, помимо личностных способностей работников, изменения обнажили такое явление, как кризис подписки. Одни из первых обратили на это внимание библиотекари Ирландии. Они опубликовали заявление к властям ЕС с просьбой стабилизировать рынок, сделать его честным и прозрачным. Чтобы признавалась важность справедливого и равноправного доступа к электронным книгам для граждан [3]. В период пандемии библиотеки почувствовали себя очень уязвимо по отношению к издателями и вендорами. Согласимся, что ценообразование крайне непрозрачно, права пользователей ограничивают лицензионными соглашениями, а главное, цифровые ресурсы не принадлежат библиотекам, как ранее книги и в любой момент (в результате финансовых проблем или правовых конфликтов) могут стать недоступны для библиотек и читателей.

Кроме того, высокая стоимость электронных информационных ресурсов не позволяет вузам обеспечить их минимальный необходимый репертуар, что привлекает академический персонал к пиратскому или серому открытому доступу. 
По этому поводу было сделано «Заявление Международной коалиции библиотечных консорциумов» (ICOLC). Основные выводы были сформулированы следующим образом:

- К любому релевантному контенту и набору данных о COVID-19, вакцинах, противовирусных препаратах и т. д., которые в настоящее время поддерживаются только по подписке, открыть доступ незамедлительно;

- Снять все ограничения на одновременных пользователей;

- Отменить существующие ограничения на копирование;

- Предоставить максимальную степень ограничений авторского права, исключений при добросовестном использовании, даже если они ограничены договором;

- Ввести гибкие периоды продления и увеличенные сроков оплаты;

- Отложить или свести к минимуму любое запланированное повышение цен. Разработать планы по временному снятию платного доступа или разработке альтернативных методов аутентификации;

- Снять ограничения подключения только на сеть кампуса [4].

Таким образом, экспертами подчеркивается необходимость наращивании потенциала библиотек через расширение модели открытого доступа, а также изменения существующих структур и механизмов интеллектуальной собственности для создания благоприятной среды. Еще одна проблема, это инертность нормативно-правовой базы, регулирующей деятельность высшей школы. Особенно в части требований к прохождению процедуры государственной аккредитации. Использование в учебном процессе цифровых информационных ресурсов до сих пор находится вне правового поля.

Помимо угроз, проявляющихся из внешней среды, не стоит игнорировать проблемы, возникающие на институциональном уровне. И тут стоит отметить недостаточно эффективную коммуникацию между 
библиотекарем и преподавателем в подборе необходимых учебных изданий к конкретным дисциплинам. При переходе на дистанционные и смешанные формы обучения преподаватель, как правило, осуществляет сопровождение дисциплин через Систему управления обучением (LMS). И для использования актуальных и авторитетных источников информации необходима совместная работа с библиотекарем. Для успеха деятельности библиотеки по данному направления наиболее верной стратегией является внедрение общей поисковой платформы, которая должна легко интегрироваться с LMS и быть совместимой со средствами обучения. Подобные задачи можно реализовать через использование системы Discovery Service. При этом вопросы инициативы и открытости библиотекаря к диологу стали значительно более актуальны, чем прежде.

Также повысилась значимость институционального репозитория, который является, на сегодняшний день, наиболее оптимальным решением для управления контентом, обеспечения доступа и хранения цифровых учебных объектов (DLO) $[5 ; 150]$.

Вместе с необходимостью формирования нового мышления и осознания неотложности изменений и выстраивания необходимой стратегии управления, можно достаточно четко определить приоритеты практической деятельности библиотек:

- Развитие инфраструктуры и формирование ресурсов открытого доступа. Оцифровка коллекций университетских изданий;

- Реализация проекта интеграций учебных изданий белорусских вузов;

- Консолидация позиции библиотек в переговорах с издателями и поставщиками электронных ресурсов (вопросы ценообразования и лицензирования);

- Создание политик юридического признания использования электронных ресурсов на государственном уровне. 
Таким образом, изменения, происходящие сегодня во всем мире, затрагивают как технологии, так и образ мышления преподавателя и библиотекаря. Готовность перестроить систему управления, внедрять новые процессы и инструменты, адаптироваться к изменениям будет служить критерием устойчивости национальной системы образования и ее конкурентоспособности на рынке образовательных услуг.

\section{СПИСОК ИСПОЛЬЗОВАННЫХ ИСТОЧНИКОВ И ЛИТЕРАТУРЫ}

1. Обращение Генерального секретаря по случаю публикации аналитической записки по вопросам образования и COVID-19 [Электронный ресурс] : от 04.08.2020 // Организация Объединенных Наций (OOH). - Режим доступа: https://u.to/I4V5Gw. Дата доступа: 05.10.2020.

2. Совместное послание Одрэ Азуле, Генерального директора ЮНЕСКО, Гая Райдера, Генерального директора Международной организации труда, Генриетты Фор, Исполнительного директора ЮНИСЕФ, Ахима Штайнера, Администратора ПРООН и Дэвида Эдвардса, Генерального секретаря Интернационала образования, по случаю Всемирного дня учителя «Молодые учителя - будущее профессии» [Электронный pecypc] : 5 окт. 2019 // Цифровая библиотека UNESDOC. - Режим доступа: https://unesdoc.unesco.org/ark:/48223/pf0000370893_rus?_cldee=c2FvdUBzYW91LmNvL nph\&recipientid=account $-1197 \mathrm{ae} 39 \mathrm{f} 39 \mathrm{bdb} 11 \mathrm{a} 8460003 \mathrm{ffb} 721 \mathrm{cc}-$ 45856166dcde4492a81364e29fe84db0\&esid=19470c60-0dcd-483a-b680-8be1068d7c6b. Дата доступа: 05.10.2020.

3. Irish librarians call for action on the electronic content crisis facing libraries and library users [Electronic resource] : news, 28 oct. 2020 // The Library Association of Ireland. Mode of access: https://www.libraryassociation.ie/irish-librarians-call-for-action-on-theelectronic-content-crisis-facing-libraries-and-library-users/. - Date of access: 05.10.2020

4. Заявление по поводу глобальной пандемии COVID-19 и ее влияния на библиотечное обслуживание и ресурсы [Электронный ресурс] : [от 13 марта 2020 г.] / [Междунар. коалиция библ. консорциумов (ICOLC)] // ICOLC (International Coalition of Library Consortia). - Режим доступа: https://icolc.net/statement/statement-global-covid-19pandemic-and-its-impact-library-services-and-resources. - Дата доступа: 05.10.2020.

5. Кулаженко, В. Г. Управление цифровыми коллекциями университета в условиях изменений на примере Фундаментальной библиотеки Белорусского государственного университета / В. Г. Кулаженко // Бібліятэчны веснік : навук. зб. / Нац. б-ка Беларусі ; [склад. Л. Г. Кірухіна, В. А. Какшынская ; рэдкал. Р. С. Матульскі (старш.) і інш.]. Мінск, 2020. - Вып. 12. - С. 148-155. 
DOI: $10.33581 / 2020-20-15-23$

\section{О РАБОТЕ БИБЛИОТЕКИ НАЗАРБАЕВ УНИВЕРСИТЕТА В УСЛОВИЯХ ПАНДЕМИИ \\ ABOUT NAZARBAYEV UNIVERSITY LIBRARY'S ACTIVITIES IN THE CONDITIONS OF THE PANDEMIC}

Лапо Петр Михайлович - генеральнылй эксперт библиотеки Назарбаев Университета (Казахстан), е-mail: piotr.lapo@nu.edu.kz

Lapo Petr Mikhailovich - General Expert of the Nazarbayev University Library (Kazakhstan), e-mail: piotr.lapo@nu.edu.kz

Аннотация: В данной статье представлен опьт работы библиотеки Назарбаев Университета в условиях пандемии по таким основным направлениям, как комплектование фондов, виртуальные услуги, просветительные мероприятия для студентов, и мероприятия по трансляциии передового международного и отечественного опыта в области современного библиотечного дела.

Abstract: This article presents the experience of Nazarbayev University Library in the context of a pandemic in such main areas as acquisition policy, virtual library services, enlighten events for students, and professional events to transmit advanced international and national experience in the field of the contemporary librarianship.

Ключевые слова: библиотечное дело, открытый доступ, библиотечный портал, политика комплектования, услуги виртуальной библиотеки, инклюзивность библиотеки, библиотечные тренинги.

Keywords: librarianship, open access, library portal, acquisition policy, virtual library services, library inclusiveness, library trainings. 
В 2020 году исполняется 10 лет со дня создания Назарбаев Университета (НУ) и его библиотеки. Недолгая история библиотеки имеет свои преимущества, прежде всего, то, что её деятельность изначально базировалась на тех тенденциях развития библиотечного дела, которые актуальны и в настоящее время. Например, с первых дней существования библиотеки НУ приоритетным направлением в комплектовании фондов было приобретение электронных информационных ресурсов (э-книг, кодов доступа (access codes) к электронным учебным материалам и кейс-методам (case-studies), размещенным на платформах ведущих университетов мира), a также обеспечение доступа к лицензионным базам данных, представляющим интерес для пользователей библиотеки, а в информационно-библиотечном обслуживании - предоставление так называемых виртуальных услуг (виртуальная справка в синхронном и асинхронном режиме, виртуальный кабинет преподавателя для формирования пакетов учебников, виртуальный читательский формуляр, виртуальные инструменты поиска информации и информирования пользователей о ресурсах и мероприятиях библиотеки и т.п.).

Поэтому объявление в университете карантина с 26 марта 2020 года и связанный с этим перевод учебы студентов и преподавания в НУ в онлайн-режим не стал проблемой для библиотеки НУ.

В то же время новые условия работы университета повлекли за собой и определенные изменения в работе его библиотеки. Например, запрос преподавателей на коды доступа возрос в 3 раза. Доля финансирования комплектования, выделяемая на приобретение э-книг, была также увеличена. Например, в августе 2020 года была осуществлена подписка на полную базу э-книг издательств Elsevier (платформа ScienceDirect, 30,622 э-книги) и Taylor \& Francis eBooks (более 120000 э-книг по естественным, техническим, социальным, гуманитарным наукам и медицине) с целью 
последующей закупки э-книг с использованием модели «evidence-based acquisitions $(\mathrm{EBA}){ }^{1}$.

Повышенный интерес к э-книгам был продиктован также и тем, что в связи с угрозой коронавируса и объявленной Всемирной организацией здравоохранения пандемией возникли трудности в доставке печатных изданий зарубежных издательств (более 80 \% фонда библиотеки составляет литература на английском языке, издаваемая такими издательствами, как Academic Press (Elsevier), Berrett-Koehler Publishers, Inc., Cambridge Scholars Publishing, Routledge \& CRC Press, De Gruyter, Pearson Education Limited, SAGE, Springer Publishing Company, LLC, John Wiley and Sons, Inc., Woodhead Publishing, Liverpool University Press, Louisiana State University Press, Pennsylvania State University Press, University of Hawai'i Press, University of Michigan Press и другими).

В течение 2020 года пользователям библиотеки предоставлялся доступ к более 33160 э-книгам, приобретенным библиотекой в «вечное» пользование, и к более 700000 э-книг благодаря подписке библиотеки на международные платформы и архивы научной информации. Благодаря подписке на 115 баз данных доступ предоставлялся также к полным текстам более 14600 научным онлайновым журналам.

Переход университета на дистанционную форму обучения и необходимость мониторинга состояния пандемии в городе, стране и мире стали причинами создания на веб-портале библиотеки раздела «COVID-19» со следующими подразделами:

- Последние оповещения для университетского сообщества (оперативное информирование о решениях руководства университета и изменениях в различных сферах жизнедеятельности университета);

\footnotetext{
${ }^{1}$ О модели комплектования Evidence based Acquisitions (EBA) можно прочитать в статье: Яцук, Е. Зарубежные электронные ресурсы: контент и сервисы в интересах пользователя / Е. Яцук [Электронный ресурс] // Университетская библиотека. - Режим доступа: http://www.unkniga.ru/biblioteki/fonds/10966-zarubezhnye-elektronnye-resursy-kontent-i-servisy-v-interesahpolzovateley. - Дата доступа: 09.04.2021.
} 
- Удаленные услуги библиотеки (информирование о как уже предлагавшихся ранее, так и новых услугах библиотеки);

- Последние новости и обновления (информирование о COVID-19 в городе, стране и мире);

- Глобальные исследования (информация о публикациях и информационных материалах в области исследования коронавирусов и COVID-19);

- Переход к онлайн-обучению (информация об инструментах, информационных ресурсах и тренингах, полезных для организации дистанционного обучения);

- Поддержка онлайн-преподавания и обучения (информация об онлайн учебниках, курсах, образовательных платформах, которые могут быть использованы в учебе и обучении);

- Полезное свободное время (информация о доступных в Интернете коллекциях книг, музыкальных и визуальных произведений, а также об открытых учебных курсах).

В подразделе «Последние новости и обновления» приведены также ссылки на информационные материалы по медийной и инормационной грамотности (media and information literacy) и инфодемии (infodemia), а также по проверке фактов (fact checking).

Поскольку для создания и сопровождения подразделов раздела «COVID-19» использовалась программа управления контентом LibGuides ${ }^{1}$ компании SpringShare, то у библиотекарей была возможность самим (без участия ИТ-специалистов) формировать и обновлять контент подразделов.

Работа НУ в дистанционном режиме, в том числе, и в начале осеннего семестра 2020 года вызвала необходимость создания на библиотечном портале раздела «Library Orientation: Welcome», в котором были размещены

\footnotetext{
${ }^{1}$ https://springshare.com/libguides/
} 
информационные материалы, а также видеоролики, знакомящие вновь поступивших в университет студентов и вновь прибывших преподавателей с ресурсами и услугами библиотеки, т.е. те материалы, которые ранее использовались во время очных ориентационных сессий. Также была подготовлена и разослана по Школам (факультетам) НУ брошюра «Онлайн ресурсы для дистанционного обучения - 2020», в которой были представлены с кратким описанием подписные как междисциплинарные БД, так и специализированные базы данных с указанием Школы, информационным потребностям которой они соответствуют.

На портале библиотеки увеличилось количество тематических путеводителей (LibGuides), в том числе и по учебным дисциплинам. Возросло количество заказов научных статей и глав из книг, получаемых пользвателями библиотеки благодаря службе электронной доставки документов, созданной в рамках сотрудничества библиотеки НУ с библиотеками Университета штата Висконсин (г. Мэдисон), Университета имени Дьюка, Питтсбургского университета и Библиотекой Конгресса США. В 2020 году был выполнен 881 заказ по ЭДД.

Как и в прежние годы проводилась работа по совершенствованию используемой в библиотеке интегрированной библиотечной системы (АБИС), разработанной ИТ-специалистами НУ, но в 2020 году обсуждения изменений в системе обсуждались на платформе Google Meet, a мониторинг разработки и внедрения изменений осуществлялся с помощью инструмента JIRA $^{1}$.

Поскольку учеба студентов в 2020 году проходила дистанционно, и доступ на кампус, в том числе, и в читательные залы был для них ограничен, то по-новому был организован домашний абонемент, благодаря которому студентам выдавались как печатные издания из фонда библиотеки, так и устройства для чтения э-книг. Иногородним студентам учебники

\footnotetext{
${ }^{1}$ https://www.atlassian.com/software/jira
} 
доставлялись с помощью службы доставки DHL за счет HУ (остальные печатные издания по заказу студентов доставлялись им из фонда библиотеки службой КазПочта за счет студентов), а студентам, проживающим в г. Нур-Султан необходимо было осуществить онлайн заказ необходимой литературы и забрать её в определенные часы в специально оборудованном помещении на пропускном пункте. Для дезинфекции возвращаемой литературы были закуплены 3 аппарата MiTAC IDSmart Sterilizer¹, использующих стерилизующий эффект ультрафиолетовых лучей, убивающих микробы и очищающих книги от пыли и мелких отходов через фильтр во время процесса стерилизации. Для стерилизации 3 книг требуется 30 секунд, степень стерилизации - 99,99\%.

Были достигнуты договоренности с публичными и университетскими библиотеками в других городах страны, где проживают студенты НУ, чтобы последним была предоставлена возможность работать в читальных залах, если такие библиотеки открыты для посещения.

В 2020 году продолжалась работа по информированию академического сообщества НУ о ресурсах, услугах и мероприятиях библиотеки посредством социальных сетей ${ }^{2}$, также был разработан и запущен в эксплуатацию с 22 июля Telegram Bot: @nulibrarybot.

Для повышения медийной и информационной культуры студентов была проведена онлайн викторина «III Library InfoLit Race Challenge (Virtual)».

Принимая во внимание большие психологические нагрузки, которым подвергаются студенты в предэкзаменационный период, усугубляющиеся условиями удаленной учебы студентов в период пандемии, библиотека в сотрудничестве с Центром психологического консультирования организовала и провела ряд онлайн мероприятий «Staying at Home»

\footnotetext{
${ }^{1}$ https://www.ab-tec.ca/index.php/idsmart-sterilizer/

${ }^{2}$ Instagram: https://www.instagram.com/library.nu.edu.kz

Facebook: https://www.facebook.com/Nazarbayev.University.Library

Twitter: https://twitter.com/NU_Library_NU
} 
and «Relieving the Stress» с целью психологической разгрузки студентов в рамках программы Stress Relief Week, с 16 по 20 ноября 2020 г.

Кроме того, библиотекой для студентов было проведено большое количество досуговых и культурных мероприятий. Например, в связи со 175-летием со дня рождения великого казахского поэта, мыслителя и просветителя Абая Кунанбаева в мае-июне 2020 г. был проведен конкурс «Абай в наших сердцах», в рамках которого студенты предоставили свои видеоролики, на которых они читают стихи великого поэта, а 8 октября совместно с библиотекой Университета штата Индиана (США) - онлайн час казахской поэзии «Абай-175: Празднуя юбилей величайшего казахского поэта», в котором приняли участие казахстанские и американские школьники, студенты и преподаватели, декламировавшие стихи Абая и исполнившие музыкальные произведения на казахских национальных музыкальных инструментах.

Отмечая 1150-летие со дня рождения выдающегося ученого Абу Насра аль-Фараби библиотекой 23 декабря была проведена среди студентов Университета историко-познавательная викторина “Аль-Фараби - великий ученый Востока". 28 декабря проведена викторина по повести Бердыбека Сокпакбаева "Меня зовут Кожа” с целью последующего обсуждения повести студентами на онлайн-платформе Zoom.

Проводились также онлайн-презентации книг, авторами которых являются преподаватели Назарбаев Университета.

Одним из основных направлений деятельности библиотеки НУ является трансляция среди казахстанских библиотекарей передового международного и отечественного опыта в области информационнобиблиотечного обслуживания.

C 30 сентября по 2 октября 2020 г. на платформе Zoom прошла IX Евразийская конференция академических библиотек (EALC), организованная совместно с Ассоциацией библиотек учреждений высшего 
образования в Республике Казахстан. В конференции приняли участие более 230 специалистов, руководителей библиотек, а также представителей поставщиков информационных ресурсов из 26 стран мира, в том числе 145 из Казахстана ${ }^{1}$.

В рамках ежегодной Школы библиотечных технологий 9-10 декабря 2020 г. библиотекой НУ был проведен вебинар-тренинг «Современная академическая библиотека: Управление, ресурсы, технологии и формы обслуживания〉 по повышению квалификации библиотекарей казахстанских вузов. В ходе вебинара были освещены две темы: (1) Открытая наука и открытый доступ: институциональные репозитории и репозитории данных; (2) Маркетинг. SMM и библиотекарь. В первый день вебинара его участниками были 316 библиотекарей и во второй день - 323. В вебинаре приняли участие руководители и специалисты университетских библиотек из многих городов Казахстана: Актобе, Алматы, Аркалык, Атырау, Караганда, Костанай, Нур-Султан, Павлодар, Петропавловск, Тараз, Талдыкорган, Уральск и других. В конце каждого дня вебинара проводился тест для закрепления полученных его участниками знаний.

С целью популяризации инклюзивного образования и создания в учебных заведениях страны условий для эффективной работы в цифровой среде учащихся, в том числе и с особыми образовательными потребностями, сотрудниками библиотеки был инициирован проект «Цифровая инклюзия», который был поддержан в рамках республиканского конкурса «Цифровое гражданство», проводившимся совместно Центром анализа и исследований кибератак, Общественным фондом «Молодёжная информационная служба Казахстана», а также Лабораторией Касперского, и который на протяжении 2020 года успешно реализовывался. В самом НУ библиотеки проводились онлайн встречи «NU Disability Talks: «Inclusion Projects in Museums

\footnotetext{
${ }^{1}$ https://nu.edu.kz/news/nu-hosted-9th-eurasian-academic-libraries-conference-ealc
} 
and Access to Arts for Persons with Disabilities»»» с целью формирования толерантной для людей с особыми образовательными потребностями среды.

Библиотека НУ продолжает свою работу по реазизации Целей устойчивого развития (ЦУР), определенных Локальной повесткой $\mathrm{OOH}$ до 2030 года, и новая успешная история библиотеки в реализации ЦУР была опубликована на виртуальной карте ИФЛА «Библиотечная карта мира». Реализованные на практике инициативы библиотеки НУ по повышению осведомленности и содействию гендерному балансу и равенству в исследованиях стали основным моментом этой истории 1 .

Результаты проведенного среди студентов НУ опроса с целью анализа их удовлетворенности различными аспектами учебы в условиях дистанционного образования показали их высокую удовлетворенность доступностью библиотечных онлайновых ресурсов $(81,2 \%$ от числа респондентов) и информационно-библиотечным обслуживанием в целом (99\% от числа респондентов).

\footnotetext{
${ }^{1}$ https://librarymap.ifla.org/stories/Kazakhstan/LIBRARY-RAISES-AWARENESS-AND-FOSTERSRESEARCH-ENABLING-GENDER-BALANCE-AND-EQUALITY/148
} 
DOI: $10.33581 / 2020-20-24-40$

\section{БИБЛИОМЕТРИЯ ОТКРЫТОГО ДОСТУПА: ОСОБЕННОСТИ ЭПОХИ СОVID-19}

\section{BIBLIOMETRICS OF OPEN ACCES: SPECIFICS OF THE COVID-19 TIMES}

Разумова Ирина Константиновна - к. ф.-м. н., заместитель директора по научной работе Наџионального электронно-информациионный консоричима (НЭИКОН) (Россия), e-mail: razumova@neicon.ru, http://orcid.org/0000-0003-0910-8010

Irina K. Razumova - Cand. Sci. Phys. and Maths, Deputy Director of Science in National electronic-information consortium (NEICON) (Russian Federation), e-mail: razumova@neicon.ru, http://orcid.org/0000-0003-0910-8010

Аннотация: Пандемия 2019 года создала уникальные условия для развития исследований в области нового коронавируса COVID-19.

В докладе освещуаются изменения в области публикационной и издательской деятельности, вызванные пандемией COVID-19. Задача решается библиометрическими методами на массиве публикациий базы Web of Science. Сравнительный анализ библиометрических показателей проведен для публикащчий трех референтных групп: в области исследований нового коронавируса, в области клинической медицины и на полном массиве публикациий Web pf Science Core Collection (WoS CC) с учетом возможных типов открытого доступа.

Зарегистрирован рост всех рассмотренных библиометрических показателей: числа публикаџий $(N), \quad$ цүитируемости (CI) и преимущесттвенного цчитирования статей открытого доступа (ОАСА) для группь COVID-публикаџчий по сравнению с результатами, полученньми 
для публикаџий в области клинической медищунны и для полного массива публикациий базы WoS CC.

Для публикаций 2020 года отмечено резкое увеличение относительной доли статей бронзового открытого доступа. Этот факт объяснен политиками ведущихх мировых издательств. Во время пандемии эти издатели размещзают статьи в области коронавируса в отдельньх коллекциях с бесплатным (бронзовым) доступом $и$ в репозиториях открытого доступа (в основном, PubMedCentral).

Анализ показывает, что возможности, предоставляемые издателями в отношении размещчения публикаций в зеленом открытом доступе (репозиториях и платформах открытого доступа), используются в настоящее время не полностью.

Рассмотрена деятельность НЭИКОН в части реализации проектов Открытого доступа, позволяющуая участникам проектов пополнять репозитории своих организацуий.

При поддержке: работа выполнена с использованием гранта № 20-3-001719 Президента Российской Федерациии на развитие гражданского общества, предоставленного Фондом президентских грантов.

Abstract: The 2019 pandemics have built the unique framework for the development of research in the field on novel coronavirus COVID-19.

The work reports on the changes in the bibliometric indicators induced by COVID-19.

In our research, we applied standard bibliometric methods on the dataset of the Web of Science platform. We comparatively analyzed three reference groups: the field of research of the novel coronavirus COVID-19, the field of clinical medicine in GIPP classification scheme (Clinical, 
Pre-Clinical\&Health), the overall dataset of publications in Web of Science Core Collection (WoS CC). The study also considers different Open Access models.

The analysis indicates an increase in the following bibliometric indicators of the COVID-group publications as compared with two other reference groups: number of publications (N), Citation Impact (CI), and Open Access Citation Advantage (OACA).

For the COVID-publications in the 2020 publication year, we detected a sharp increase in the percent share of Bronze OA publications. This can be explained by the OA policies of the world-leading publishers. During the novel coronavirus pandemics, publishers locate the COVID-publications in separate collections with free (Bronze) access and also post them on repository platforms (as a rule, in PubMedCentral).

Our results demonstrate the low intake of the possibilities for repository posting provided by the publishers' policies towards the Green OA. This is especially the case for the overall array of WoS CC publications.

We report on the NEICON activity in the realization of the Open Access projects that help our member organizations to legally populate their institutional repositories.

Funding: grant \# 20-3-001719 of the President of the Russian Federation for the development of civil society provided by the Fund of Presidential Grants.

Ключевые слова: библиометрия, открытый доступ, Gold OA, Hybrid OA, Bronze OA, Green OA, репозитории открытого доступа, COVID-19

Keywords: bibliometrics, open access, Gold OA, Hybrid OA, Bronze OA, Green OA, open access repositories, COVID-19 


\section{Введение}

Во время пандемии и на фоне самоизоляции общество убедилось, с какой скоростью и в каких объемах распространяется медийная информация. Зачастую это информация непрофессиональная, недобросовестная и тенденциозно поданная, имеюшая целью максимальный объем продаж. Во многом благодаря этому, за короткое время после объявления пандемии весь мир охватили страх и неуверенность. Стали очевидными задачи повышения информационной грамотности населения: критическое мышление, умение искать авторитетную информацию, умение анализировать подаваемую информацию.

Помимо задач предоставления и использования информации возникает задача организации надежного и легального удаленного доступа, основанного на удаленной аутентификации и авторизации пользователей.

Во время пандемии стала очевидной необходимость альтернативы инфодемии ${ }^{1}$ в виде достоверной информации о коронавирусах, которая распространяется также свободно и мгновенно, как и медийная информация. О необходимости информационной поддержки и открытого обмена научной информацией о COVID-19 заявляли многие межправительственные и общественные организации ${ }^{2}$.

В ответ на вызовы пандемии и самоизоляции в большинстве издательств была реализована ускоренная и упрощенная схема публикации

\footnotetext{
1 https://ru.wikipedia.org/wiki/конспиралогические_теории_o_пандемии_COVID-19\#cite_note-Lowy-3 2 февраля 2020 года Всемирная организация здравоохранения объявила альтернативные версии «инфодемией» (ㅎгл. infodemic), которая представляет опасность для всемирного здравоохранения 2 Глобальный совет по мониторингу готовности к глобальным кризисам в здравоохранении, ГМГЧС*. Global Preparedness Monitoring Board, GPMB 30 января 2020, Женева https://apps.who.int/gpmb/assets/news/GPMB\%20Statement\%20on\%202019\%20nCoV.pdf Руководители науки стран G20. 13 марта 2020. Обращение руководителей науки стран G20 к издателям: "Мы поддерживаем обращение GPMB от 30 января 2020 г. и просим обеспечить свободный доступ, повторное использование и text-mining результатов исследований коронавирусов, SARS-CoV-2 и COVID-19."Заявление Welcome Trust COVID-19 от 13 марта 2020 г.: "Sharing research data and findings relevant to the novel coronavirus (COVID19)". Немедленный открытый доступ ко всем релевантным рецензируемым публикациям по крайней мере на время действия опасности. Немедленное размещение статей на серверах препринтов ДО публикации в журнале или на открытых платформах перед рецензированием со ссылками на доступ к первичным данным." - https:/wellcome.org/coronavirus-covid-19/open-data Обращение международной коалиции библиотечных консорциумов (ICOLC) от 13 марта 2020 г.
} 
статей в области COVID. Издатели создали COVID-коллекции и разместили их в бесплатном доступе (Бронзовый ОД) и в репозиториях, в основном в PubMed Central. Страны, общественные организации, крупные университетские и национальные репозитории, а также ЕС создали либо отдельные, либо интегрированные COVID-репозитории ${ }^{1}$.

В результате возникла ситуация, анонсированная в разных странах как конечная цель государственных программ по ОД: перевод в ОД подавляющего числа публикаций в области нового коронавируса.

Задача данного исследования - изучить изменения библиометрических характеристик научного выхода в рамках уникальной ситуации, сложившейся в условиях наибольшего благоприятствования открытому доступу.

\section{Материалы и методы}

В работе исследован контент базы WoS CC в рамках трех референтных групп публикаций: полный массив публикаций базы WoS CC, массив COVID-публикаций базы WoS CC, сформированный по результатам оригинального запроса с использованием ключевых слов $[1,2]$ и массив публикаций в области Clinical, Pre-Clinical \& Health по классификатору GIPP базы InCites: (OVERALL; Social Sciences; Physical Sciences; Life Sciences; Engineering \& Technology; Clinical, Pre-Clinical \& Health; Arts \& Humanities).

Отметим, что массив COVID-публикаций на $64 \%$ состоит из публикаций в области Clinical, Pre-Clinical \& Health, т.e. он составляет небольшую часть, на которую распространяется режим наибольшего благоприятствования ОД. При этом доля COVID-публикаций в массиве PreClinical \& Health составляет всего 5 \% и не вносит искажения в показатели

\footnotetext{
${ }^{1}$ OpenAIRE (Евросоюз):COVID-19 Open Research Gateway (https://beta.covid-19.openaire.eu/); IRUS-UK, JISC Великобритания: https://irus.jisc.ac.uk/coronavirus; CORE Великобритания: CORE (https://core.ac.uk/search?q=COVID-19); HAL Франция: https://hal.archives-ouvertes.fr/; CSIC, DIGITAL.CSIC Испания (в процессе): digital.csic.es; Канада CARL: https://www.carl-abrc.ca/advancing-research/institutionalrepositories/; Южная Корея KISTI - https://www.kisti.re.kr/eng/; La Referencia - агрегатор репозиториев 10 стран Латинской Америки: http://www.lareferencia.info/
} 
для всего массива. Можно считать, что мы сравниваем два массива, близких по области исследования, но имеющие существенное отличие: контент первого массива создается и существует в режиме наибольшего благоприятствования ОД, а основную часть контента второго массива составляют статьи, не пользующиеся этими преимуществами.

В разрезе ОД мы исследовали следующие референтные группы: подписные (закрытые) статьи, доступные только по подписке (paywall); статьи Зеленого ОД (Green OA) - статьи, размещенные в репозиториях открытого доступа или на платформах ОД и статьи Золотого ОД (Gold OA).

По классификации WoS это статьи ОД, опубликованные в журналах. Статьи Золотого ОД разбиты на три группы в соответствии с классификацией WoS: DOAJ Gold - статьи базы журналов полностью открытого доступа DOAJ1, Hybrid, Bronze. Определения каждой группе даны в таблице работы [1] и на сайте поддержки WoS CC.2

Подчеркнем, что группы DOAJ, Hybrid по определению состоят из публикаций, имеющих лицензию Creative Commons (CC)3, а для статей Bronze это по определению не так или не известно.

В каждой референтной группе мы исследовали следующие библиометрические индикаторы: число статей, $\mathrm{N}$, доля статей в общем массиве публикаций, число цитирований, C; цитируемость (Citation Impact, $\mathrm{CI}): \mathrm{CI}=\mathrm{C} / \mathrm{N}-$ среднее число цитирований на одну статью. Преимущественная цитируемость статей ОД отношение Citation Impact публикаций ОД к Citation Inpact закрытых статей: CI(OA)/CI(PW)

\section{Результаты и обсуждение}

1. Рост числа и относительной доли статей ОД в зависимости от года публикацчии

\footnotetext{
${ }^{1}$ Directory of Open Access Journals, DOAJ: www.doaj.org

${ }^{2}$ Web of Science Core Collection Help https://images.webofknowledge.com/WOKRS533JR18/help/WOS/hp_results.html\#dsy10670-TRS_open_access

${ }^{3}$ Creative Commons (CC) https://creativecommons.org/
} 
На Рис. 1a, 1b приведена динамика числа публикаций в двух референтных группах: 1. общего массив публикаций WoS CC; 2. массива COVID-публикаций. Данные получены в WoS CC по состоянию на сентябрь 2020 г.
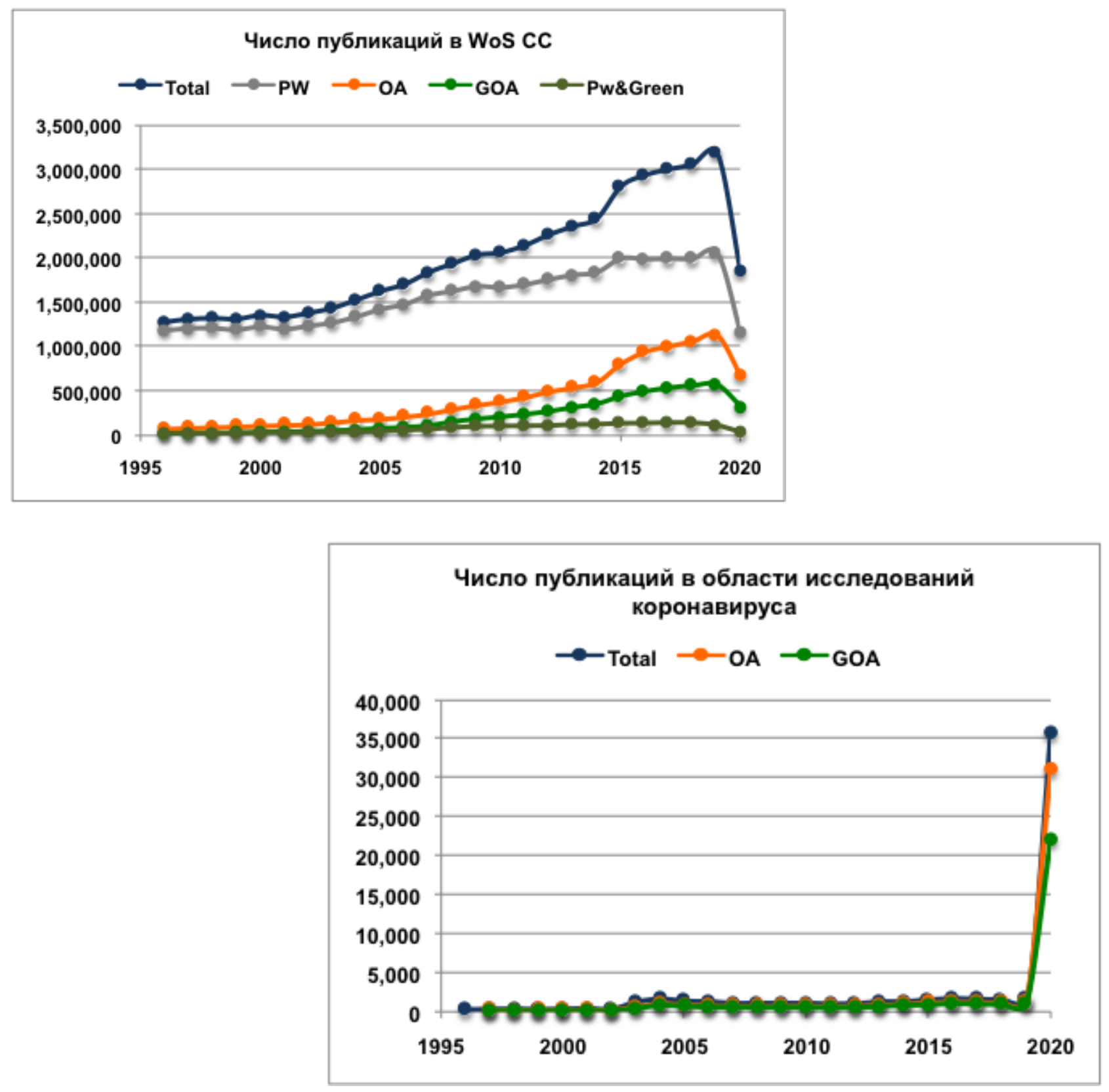

Рис. 1. Динамика числа публикащий базы WoS CC для общиго массива публикащий базы (2a) и публикаций в области исследований нового коронавируса (2b).

Зависимость от года выхода статей, РY.

Данные на сентябрь 2020 г 

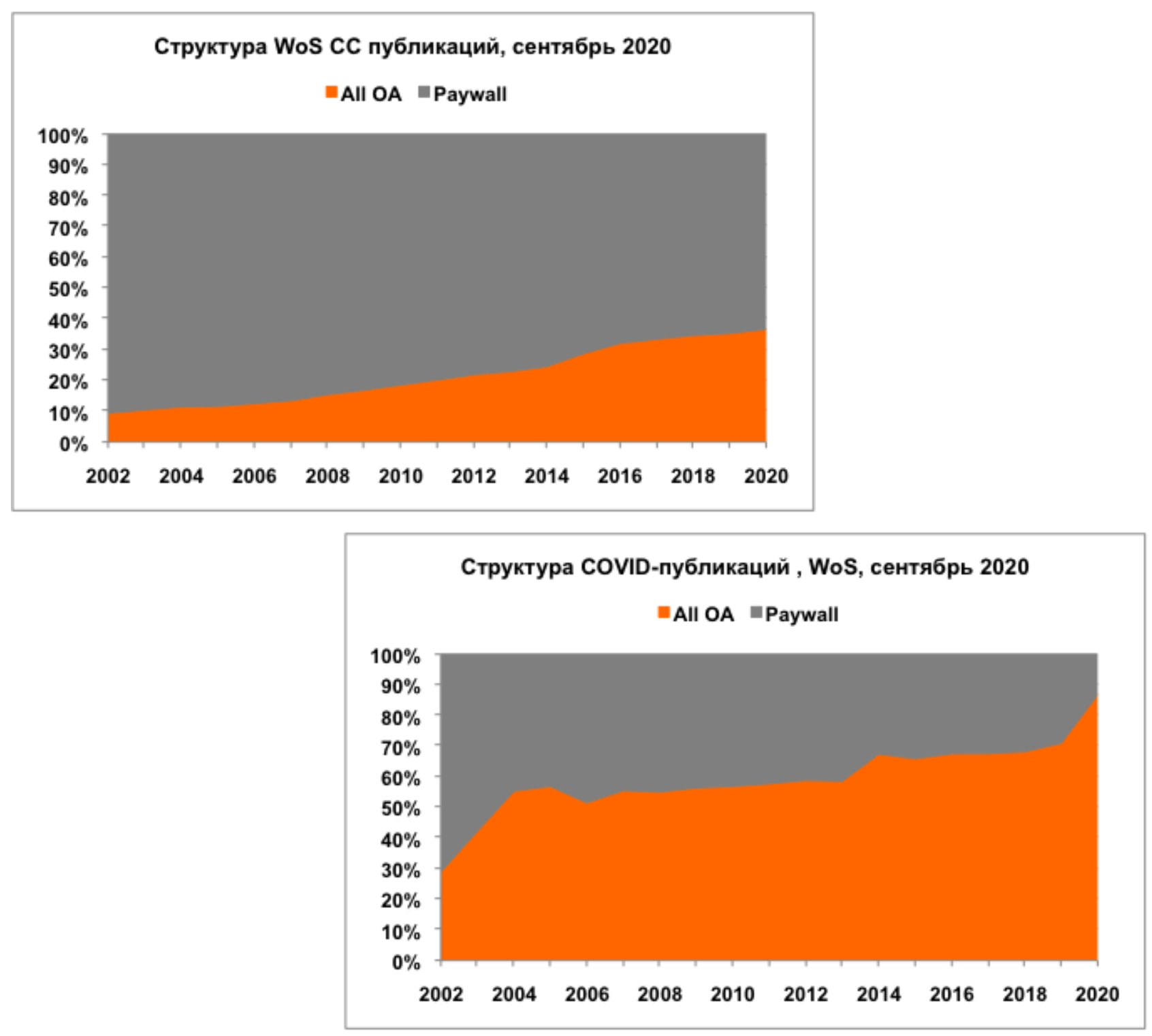

Рис. 2. Динамика структуры публикаций базы WoS CC для общего массива публикаций базы (2a) и публикаций в области исследований нового коронавируса (2b).

Зависимость от года выхода статей, РY.

Данные на сентябрь 2020 г

Из результатов на диаграммах следует, что доля ОД в общем массиве публикаций WoS CC для PY= 2020 равна 38 \%, а для массива массив COVIDпубликаций - равна $87 \%$. То есть, 9 из 10 статей в области нового коронавируса, опубликованных в 2020 году были статьями открытого доступа. 
Структура исследованных массивов публикаций в разрезе типов доступа приведена на Рис. 3. Данные базы WoS CC получены в октябреноябре 2020 г для статей, опубликованных в 2020 году.

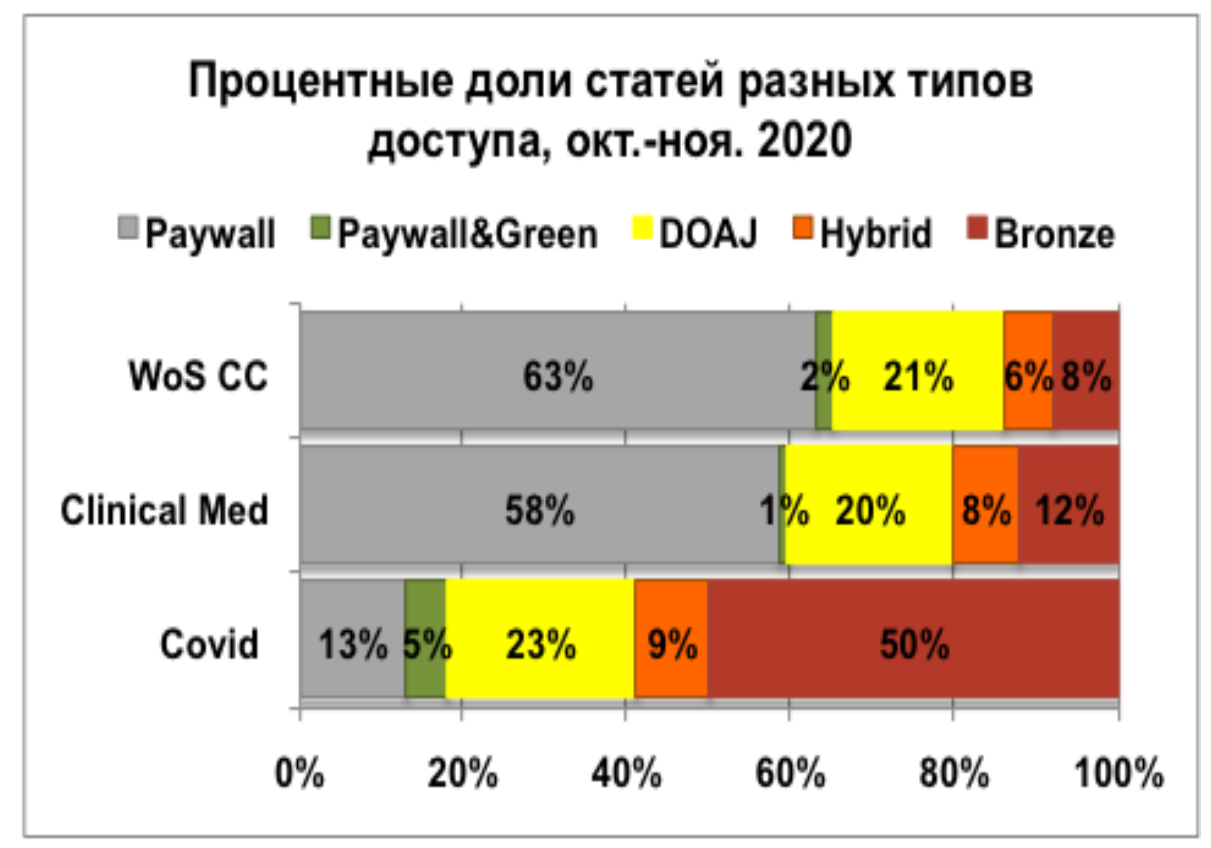

Рис. 3. Структура трех массивов публикаиий 2020 года в разрезе типов доступа. Данные WoS CC по состоянию на октябрь-ноябрь 2020 г.

Из рисунка следует, что в 2020 г. доли числа статей DOAJ (21 \% - 20 \% $-23 \%)$ и Hybrid (6\% - 8\% - $9 \%)$ во всех исследованных группах одинаковы. Основные различия приходятся на группы закрытых статей (63\% - $58 \%-13 \%)$, закрытых статей, размещенных в репозиториях (2 \% $1 \%-5 \%)$ и главное - за счет статей бронзового ОД (8 \% - $12 \%-50 \%)$.

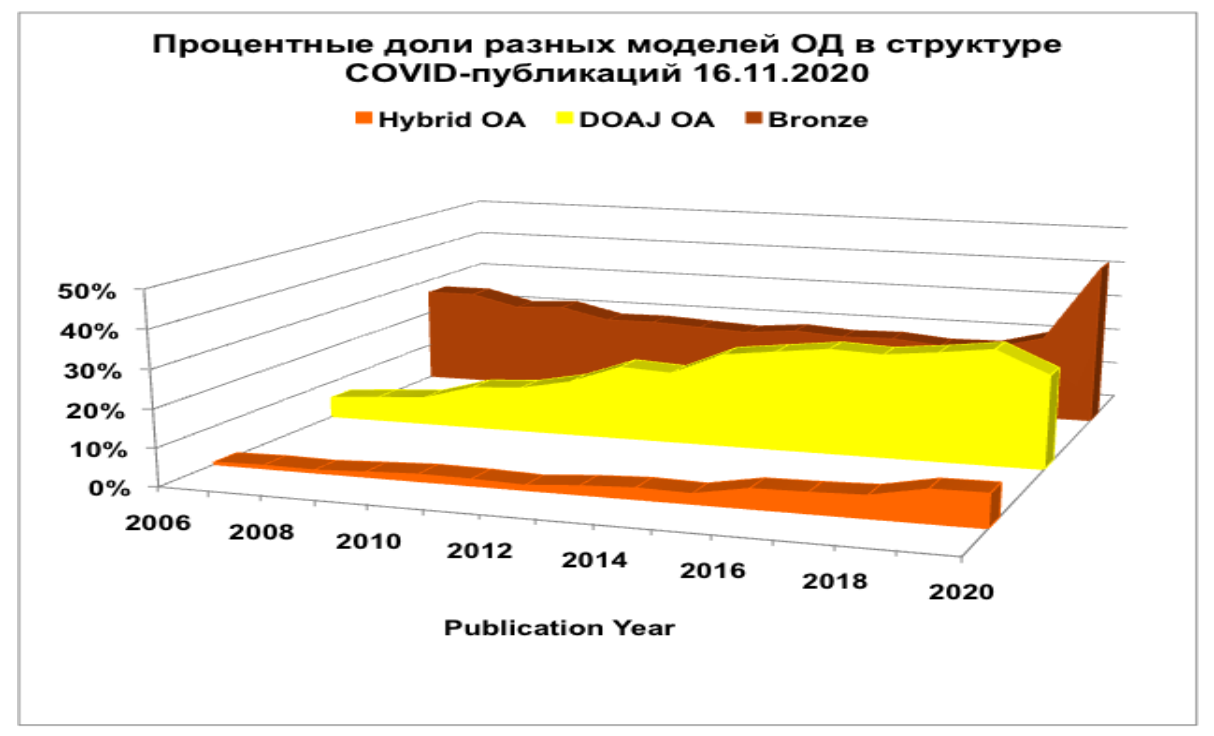

Рис. 4. Структура массивов публикаций в разрезе типов доступа.

Данные WoS CC по состоянию на октябрь-ноябрь 2020 г. 
Это же подтверждают и результаты исследования динамики относительной доли статей разных групп ОД (Рис. 4).

Обращает на себя внимание резкий рост процентного содержания статей бронзового открытого доступа в 2020 году, т.е. за время пандемии COVID-19.

Объяснить наблюдаемые закономерности можно следующими причинами. В ответ на вызовы пандемии и призывы руководящих структур и общественных организаций издатели создали COVID-коллекции публикаций в своих журналах и разместили их в ОА и в репозиториях, в основном в PubMed Central. Эти статьи доступны только для бесплатного прочтения, они не имеют лицензии СС и не могут быть отнесены к гибридному ОА или DOAJ ОА. Это статьи бронзового ОД.

\section{2. Метрики ц̧итирования}

Результаты сравнительного анализа метрик цитирования статей, опубликованных в период пандемии, приведены на Рис. 5 (цитируемость, СI) статей ОД и Рис. 6 (преимущественное цитирование открытого доступа, $\mathrm{OACA}=\mathrm{CI}(\mathrm{OA}) / \mathrm{CI}(\mathrm{pw}))$.

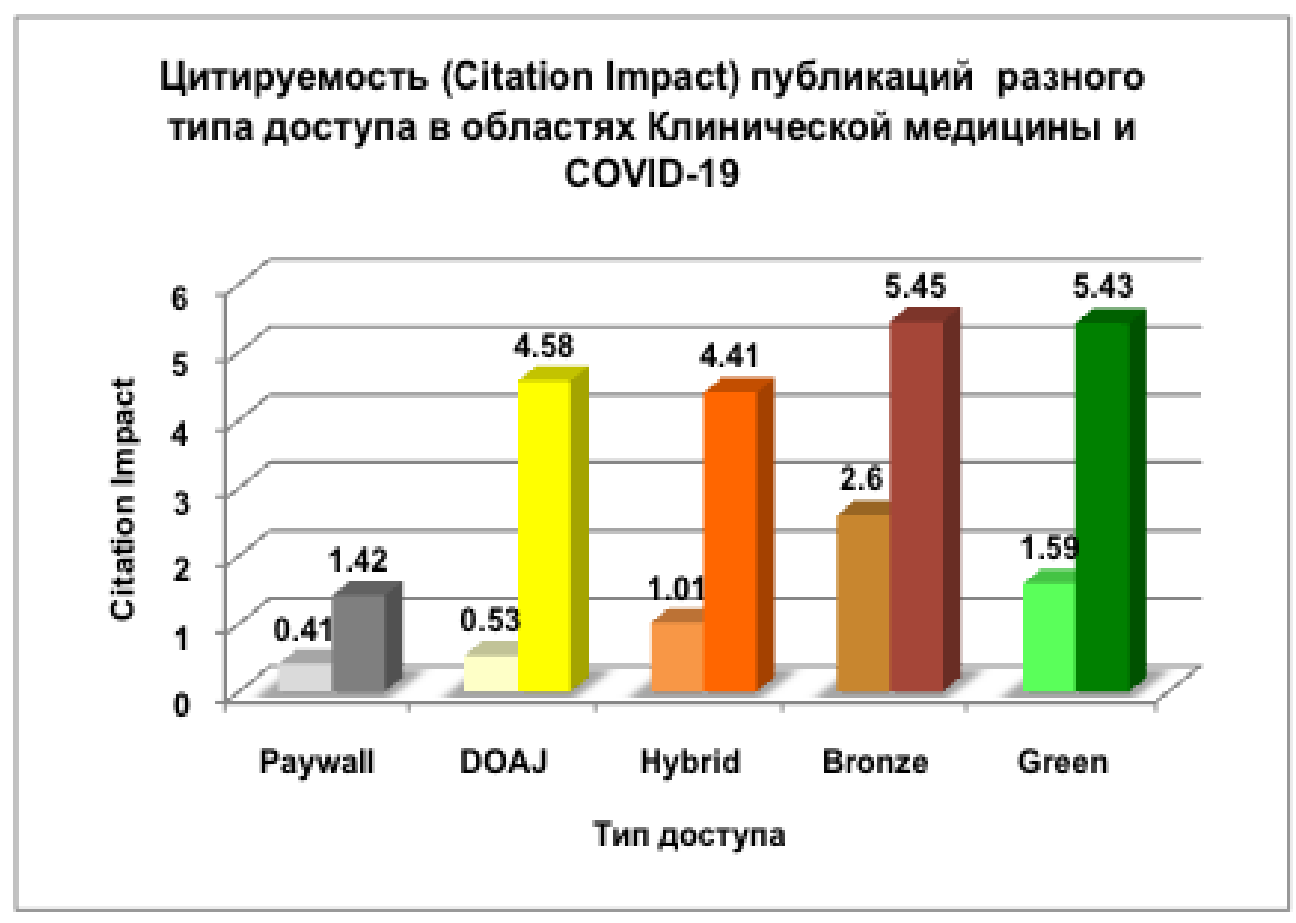

Рис. 5. Сравнение показателей цчитируемости статей $в$ области нового коронавируса и области клинической медицинь. $P Y=2020$ 2.

Данные WoS CC по состоянию на октябрь-ноябрь 2020 2. 
На Рис. 5 сопоставлены значения цитируемости статей (СI) 2020 года в разных группах COVID публикаций (бо́льшие значения) и публикаций в области Клинической медицины (меньшие значения).

Для каждой группы на массиве публикаций в области нового коронавируса зарегистрированы значения цитируемости в $2-8$ раз превосходящие цитируемость статей в области клинической медицины. Наибольшие значения цитируемости получены для массивов статей бронзового и зеленого ОД.

Цитируемость публикаций Gold OA по сравнению с «закрытыми» публикациями WoS CC в разных областях исследования, ноябрь 2020 г. приведена на Рис. 6.

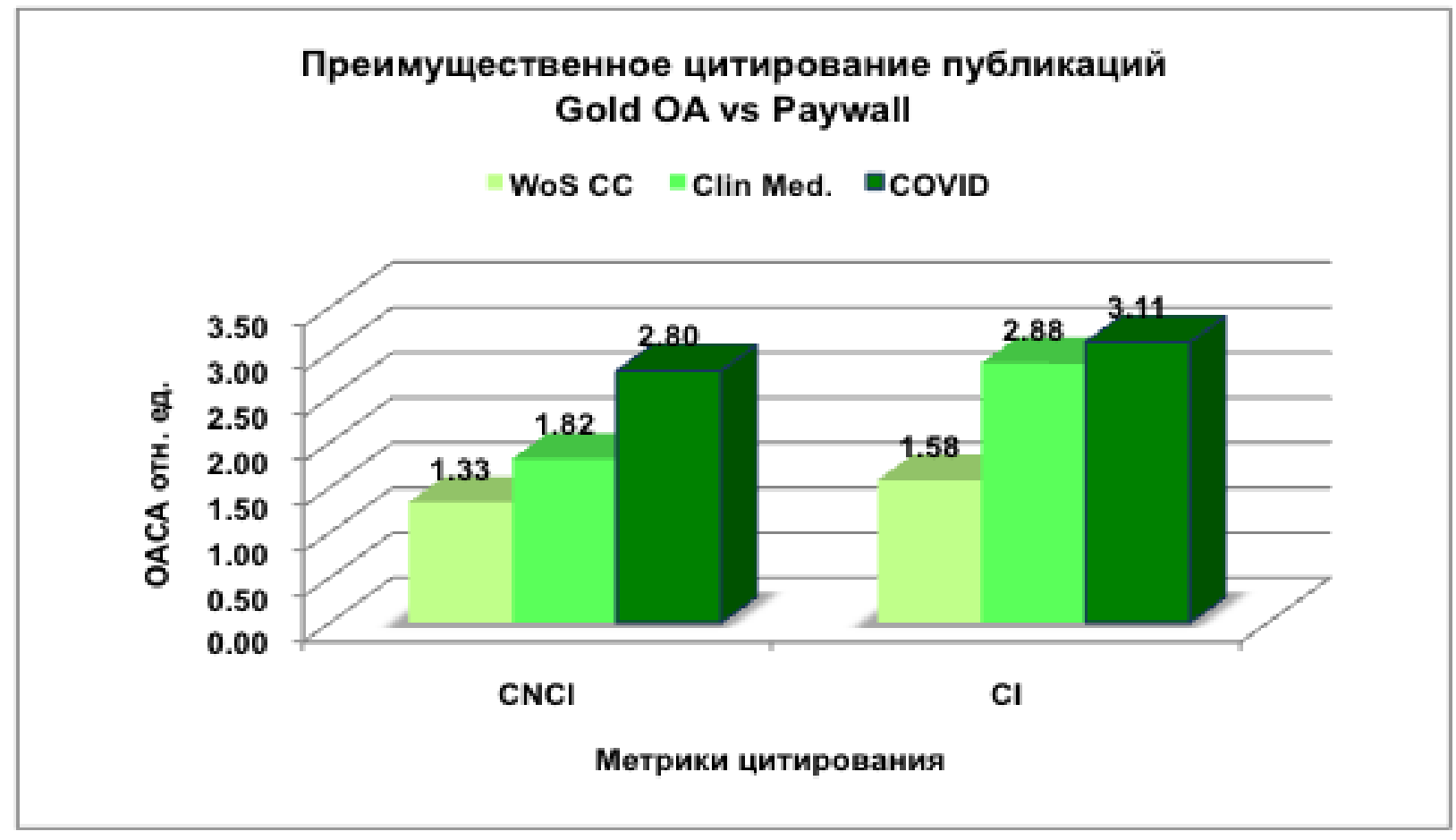

Рис. 6. Сопоставление преимущественного цитирования журнальных публикаций открытого доступа по сравнению с “закрытыли” публикаииями WoS CC в разных областях исследования. Год публикаиии 2020 г.

Данные базы WoS CC по состоянию на ноябрь 2020 г.

Результаты представлены для двух способов расчета величины ОАСА, обозначенных на рисунке как CI и CNCI. Citation Index, CI - для величины OACA, определенной как отношение значений CI: $(\mathrm{OACA}=\mathrm{CI}(\mathrm{JA}) / \mathrm{CI}(\mathrm{pw})$; 
Category Normalized Citation Index, CNCI - величины OACA, определенной как отношение значений CNCI - нормализованного по категории значения CI: $(\mathrm{OACA}=\mathrm{CNCI}(\mathrm{JA}) / \mathrm{CNCI}(\mathrm{pw})(\mathrm{JA}) / \mathrm{CI}(\mathrm{pw})$. Оба подхода дают близкие результаты.

Статьи в области исследований нового коронавируса демонстрируют наибольшие значения OACA: 1.33-1.82-2.8, соответственно, для общего массива статей базы WoS CC, статей в области клинической медицины и статей в области COVID-19

\section{3. Доля статей, размещенных в зеленом ОД}

Наш анализ показывает, что доля журнальных COVID-публикаций 2020 года, которые были дополнительно размещены в репозиториях ОД составила в 2020 году 74 \%. Для статей DOAJ и Hybrid это значение еще выше: 85-90 \%. Можно предположить, что эта цифра объясняется тем, что размещение COVID-публикаций в репозиториях обеспечивают сами издатели.

B отличие от COVID-публикаций, доля публикаций в общем массиве базы WoS CC, размещенных в зеленом ОД, гораздо ниже. В 2020 году в репозиториях были размещены $60 \%$ статей журналов базы DOAJ, $50 \%$ статей ОД в гибридных журналах (Hybrid OA). И это при том, что все эти статьи опубликованы под свободной лицензией Creative Commons и могут быть размещены в репозиториях как авторами, так и любыми другими лицами и организациями.

Тем самым, возможности для самоархивирования, предоставляемые издателями полностью не используются. Репозитории пополняются плохо. Ситуация со статьями бронзового ОД и закрытыми статьями еще хуже: в репозиториях размещаются только $20 \%$ статей бронзового ОД и только 4-6 \% статей в подписных журналах.

Рассмотрим возможные причины такой ситуации. Размещение бронзовых и закрытых статей в ОД - трудозатратное занятие, поскольку 
необходимо выяснить условия, на которых издатель разрешает это делать. Решение о размещении в репозитории статей без лицензии СС принимают сами авторы. Авторы хотят заниматься наукой и не хотят определять правовой статус своих публикаций. Авторы плохо представляют, какие права в части самоархивирования предоставляют им издатели, но в то же время опасаются нарушить авторскую лицензию. Однако тратить время на просмотр авторской лицензии издателей авторы не хотят. Помощь авторам должны оказывать их организации или организации, поддерживающие российские репозитории.

В рамках трех проектов поддержки открытого доступа, реализуемых НЭИКОН с 2018 года, мы выполняем работы, результаты которых могут помочь участникам проектов пополнить репозитории своих организаций $[3,4]$. Для всех организаций-участников с помощью сервисов баз WoS CC и Scopus мы получили списки статей их авторов, опубликованных по моделям DOAJ/Hybrid, то есть, имеющих лицензию CC.

Используя базу данных журналов платформы SHERPA / RoMEO (https://v2.sherpa.ac.uk/romeo), мы получили списки закрытых статей, и статей бронзового ОД, которые издатели разрешают размещать в репозиториях и на других открытых платформах.

Сопоставив полученные списки со списками статей, уже имеющихся в репозитории организации, мы получили списки статей, которые могут быть легально добавлены в репозитории. Результаты для 15 организацийучастников проектов НЭИКОН приведены в Таблице 1. 
Таблица 1. Число статей, которые могут быть дополнительно размещены в репозиториях российских организаций - участниов проектов «Национальный агрегатор открытых репозиториев российских университетов» $u$ «Открытая наука России». Результаты анализа базы данных WoS CC для PY=2015-2019 г2.

\begin{tabular}{|c|c|c|}
\hline Организация & $\begin{array}{c}\text { Число статей ОД для } \\
\text { пополнения репозитория } \\
\text { организации }\end{array}$ & $\begin{array}{c}\text { Число закрытых статей для } \\
\text { пополнения репозитория } \\
\text { организации }\end{array}$ \\
\hline 1 & 5947 & 12844 \\
\hline 2 & 3929 & 6844 \\
\hline 3 & 2410 & 3996 \\
\hline 4 & 1916 & 2935 \\
\hline 5 & 1281 & 2947 \\
\hline 6 & 998 & 989 \\
\hline 7 & 583 & 1545 \\
\hline 8 & 441 & 868 \\
\hline 9 & 389 & 3459 \\
\hline 10 & 377 & 1039 \\
\hline 11 & 360 & 1048 \\
\hline 12 & 302 & 332 \\
\hline 13 & 240 & 190 \\
\hline 14 & 227 & 2695 \\
\hline 15 & 134 & \\
\hline
\end{tabular}

Метаданные всех статей, отобранных для пополнения репозиториев и полные тексты статей ОД были загружены в специально созданный репозиторий на платформе openrepository.ru. Материалы доступны организациям-участникам проектов и передаются в организации по запросу уполномоченных лиц.

Как показывают результаты опросов НЭИКОН об отношении российских ученых к ОД [2, 3], авторы зачастую считают возможным размещать свои статьи в академических социальных сетях. И в то же время авторы считают, что для продвижения своего исследования достаточно разместить статью в соцсети и/или на своей домашней странице. 
Чтобы получить информацию по этим вопросам, мы проанализировали политики издателей по отношению к Зеленому ОД. Для этого мы провели библиометрический анализ массива журналов платформы SHERPA / RoMEO (https://v2.sherpa.ac.uk/romeo).

Используя API платформы Sherpa/Romeo, мы выгрузили полную информацию о журналах 5000 издателей, представленных на платформе. Были проанализированы журналы издательств, в которых были опубликованы статьи участников проектов НЭИКОН.

Для каждого из интересующих нас журналов мы выгрузили значения переменных: ISSN журнала («id»); название журнала («title»), название версии публикации («version»). Платформа SHERPA / RoMEO рассматривает три версии публикаций: представленная (submitted); принятая (accepted) и публикованная published.

Значения следующих переменных отвечают на вопросы: где можно размещать репозиторную копию публикации («location»), когда еe можно размещать (период «еmbargo») и какую лицензию можно использовать при размещении статьи в репозитории («license»).

Материалы анализа составят предмет отдельной публикации. Здесь приведем некоторые данные для статей, которые издатели разрешают размещать в версии Accepted (версия статьи, прошедшей рецензирование и принятой к печати, но не прошедшей финальную корректуру).

Итоги анализа данных Sherpa/Romeo для выборки журналов, опубликовавших в 2015-2019 гг статьи российских авторов - сотрудников организаций-участников проектов НЭИКОН.

Домашняя страница автора: 90 \% издателей, разрешают авторам размещать свои статьи в версии Submitted/Accepted, и только 56 \% издателей разрешают размещать версию Published. Институциональный репозиторий: версию Accepted разрешают размещать 90 \% издателей, Published - 32 \%, 
Submitted - $30 \%$. То есть версия Аccepted наиболее приемлема для издателей в части размещения в институциональных репозиториях.

Академические соцсети: Submitted - $16 \%$, Accepted - $18 \%$, Published только $2 \%$.

Таким образом, очень немногие издатели разрешают размещать свои статьи в академических соцсетях.

Репозитории препринтов: версия Submitted - $36 \%$.

\section{Выводы}

В результате мер поддержки исследований в области нового коронавируса создана уникальная ситуация, когда доля статей открытого доступа в общем потоке COVID публикаций составила $87 \%$. То есть, 9 из 10 статей в области нового коронавируса, опубликованных в 2020 году, были статьями открытого доступа.

Структура массива COVID-публикаций отличается высокой относительной (50 \%) долей статей бронзового открытого доступа.

Динамика относительной доли статей разных групп открытого доступа демонстрирует резкое увеличение этого показателя для статей бронзового открытого доступа на временном интервале менее одного года.

Указанные изменения величины относительной доли статей бронзового открытого доступа могут быть объяснены политикой издательств, предоставляющих бесплатный доступ к COVID-публикациям в своих изданиях и размещающих их в репозиториях открытого доступа.

По сравнению в общим массивом публикаций и публикаций в области клинической медицины, COVID-публикации демонстрируют повышенные в несколько раз показатели цитируемости (CI) и преимущественного цитирования открытого доступа (ОАСА).

Доля COVID-публикаций, размещенных в репозитории (публикаций зеленого открытого доступа), составляет 75-90 \%. 
Доля статей из общего массива публикаций базы $\mathrm{WoS}$, размещенных в репозиториях составляет $20 \%$ для статей бронзового ОД и 6 \% для статей из подписных журналов.

Предложены меры поддержки репозиториев открытого доступа российских организаций, позволяющие увеличить их наполнение. Использована информация платформы SHERPA / RoMEO о политиках мировых издательств по отношению к Зеленому ОД.

\section{Библиографические ссылки}

1. Разумова, И. К. Пандемия COVID-19 и режим самоизоляции: влияние на библиометрические показатели и использование научных публикаций. Часть І. Число и структура публикаций [Электронный ресурс] / И. К. Разумова // Наука и научная информация. - 2020. - Т. 3, № 2/3. - С. 166-187. Режим доступа: https://doi.org/10.24108/2658-3143-2020-3-2-3-166-187. - Дата доступа: 12.01.2020.

2. Разумова, И. К. Открытый доступ в «режиме наибольшего благоприятствования»: заглянем в светлое будущее через «дверной глазок» пандемии [Электронный ресурс] / И. К. Разумова // Наука, технологии и информация в библиотеках (LIBWAY-2020) : междунар. науч.-практ. конф., 14-17 сент. 2020 г. - Новосибирск, 2020. - Режим доступа: https://www.libway.ru/2020/conference/program/5f587c8fbdfce3650b79ae94. - Дата доступа: 12.01.2020.

3. Разумова, И. К. Автоматическое пополнение репозитория организации с использованием поисковых предписаний, API Scopus и API Sherpa/Romeo. Часть I. Поисковые предписания [Электронный ресурс] : [презентация] / И. К. Разумова. - Режим доступа: https://conf.neicon.ru/materials/77-online0520/20200528Razumova.pdf. - Дата доступа: 28.05.2020.

4. Косяков, Д. В. Автоматическое пополнение репозиториев организации [Электронный pecypc] / Д. В. Косяков. - Режим доступа: https://conf.neicon.ru/materials/77online0520/20200528-Kosyakov.pdf. - Дата доступа: 28.05.2020. 
DOI: $10.33581 / 2020-20-41-50$

\section{ЛУЧШИЕ ПРАКТИКИ ОБУЧЕНИЯ РАБОТЕ С ДАННЫМИ: ОПЫТ ЗАРУБЕЖНЫХ УНИВЕРСИТЕТСКИХ БИБЛИОТЕК И ЦЕНТРОВ}

\section{BEST PRACTICES FOR DATA MANAGEMENT LEARNING: FOREIGN UNIVERSITY LIBRARIES' AND PROFESSIONAL RESEARCH CENTRES' EXPERIENCE}

Маслова Анастасия Васильевна - заведуюший отделом поддержки исследований Научной библиотеки РАНХиГС (Россия), maslovaav@ranepa.ru

Maslova A. V. - Head of the Research Support Department of the RANEPA Library(Russian Federation), maslova-av@ ranepa.ru

Аннотация: на сегодняшний день не осталось сомнений в том, что в исследовательском сообществе растет потребность в работе с данными. Однако, помимо самих данных, исследователям нужна дополнительная поддержка, ведь прочесс планирования, сбора, обмена, хранения данных также требует усилий и средств. Сейчас существует несколько международных иентров и библиотечных инициатив, которые помогают исследователям организовать правильный процесс работы с данными. Многие из них выходят на крупные образовательные площадки и делятся своим опытом. В данном тексте рассмотрим лучшие практики и инициативы по обучению работы с данными, которые предлагают ведущие исследовательские центры и университеты, профессиональные онлайн курсы по менеджменту данных в академической среде.

Abstract: No doubt, that there is a growing need in the research community to work with data. In addition to the data itself, researchers need support, because the process of planning, collecting, sharing, and storing data also requires effort. Now there are several international centers and library initiatives that help researchers organize the correct process of working with data. Many of them use 
large educational platforms and share their experience. We will look at the best practices and initiatives for training in working with data offered by leading research centers and universities, professional online courses on data management.

Ключевые слова: менеджмент данных, исследовательские данные, онлайн курсы по менеджменту данных, обучение работе с данными.

Keywords: Data Management, Research Data, professional online courses on data management, data curation.

Темы, касающиеся использования исследовательских данных, сегодня широко обсуждаются разными специалистами в академической среде. Несмотря на фундаментальную важность обучения тому, как именно необходимо управлять данными (хранить, передавать или искать), в подобных дискуссиях основной упор делается скорее на обсуждение инструментов для анализа данных, например, возможности их обработки c помощью Python или R. B этом тексте речь пойдет не об инструментах, а как раз о практиках и инициативах по обучению работе с данными, которые предлагают ведущие исследовательские центры, университеты и профессиональные онлайн курсы по менеджменту данных.

Прежде чем начать разговор о конкретных практиках обучения работе с данными необходимо пояснить, почему важно говорить о менеджменте данных именно сейчас, и почему в рамках разговора об этом желательно делать акцент не на технологиях и инструментах анализа данных, а именно на обучении людей и закреплении у них навыков работы с исследовательскими данными.

Менеджмент данных - это целый набор разных практик, направленных на хранение, поиск, распространение и обмен данными. Помимо этого, деятельность по управлению данными также включает в себя планирование, 
форматирование,

документирование,

анонимизацию

данных

и управление доступом к данным. Озвученные практики, несмотря на рутинность, в действительности требуют, как минимум, большего вовлечения и концентрации со стороны исследователей, библиотекарей или центров по поддержке исследований, чем просто изучение отдельных программ и технологий. Простое понимание универсальных методов обработки данных, например, с помощью программирования, в отличии от полноценного обучения навыкам поиска, распространения и хранения данных, не дает исследователям комплексного понимания того, куда в настоящий момент движется та или иная научная дисциплина. К тому же, когда исследователь четко понимает, какие исследовательские данные ему нужны, где их можно найти, как правильно их хранить, как описывать, как должен быть спланирован процесс использования и распространения данных, это дает возможность не просто правильно использовать данные в исследованиях, но и делать их более качественно.

Акцент на обучении работе с данными необходим сегодня по нескольким причинам. В долгосрочной перспективе не технологии, а именно навыки качественного управления данными позволят, во-первых, поддерживать коммуникацию между отечественными и зарубежными исследовательскими коллективами, а во-вторых, сохранять данные для будущих исследователей. Также в краткосрочной перспективе не высококлассные навыки программирования, a именно грамотно выстроенный менеджмент данных поможет ученым лучше продвигать результаты своих научных исследований и успешно сотрудничать с авторитетными мировыми научными журналами, издательствами, фондами, грантодателями, научно-исследовательскими институтами.

На сегодняшний день курсы по менеджменту данных уже не редкость. Существуют зарубежные центры, которые занимаются темой обучения работе с данными, а также профессиональные онлайн курсы. Некоторые 
из них представлены на популярных образовательных платформах, вроде Coursera, Canvas, FutureLearn. Готовые обучающие курсы по менеджменту данных направлены на развитие конкретных исследовательских и административных навыков у разных целевых аудиторий. Исследователи, благодаря таким курсам, смогут разобраться, как управлять «своими» данными и работать с «готовыми». Для преподавателей и студентов курс по управлению данными может стать хорошим подспорьем для того, чтобы лучше разобраться в изучаемой научной дисциплине. Для научных администраторов и библиотекарей опыт зарубежных центров по управлению данными поможет лучше понять, как данные встраиваются в научные исследования. Такой курс также поможет тем, кто вовлечен в процесс исследования только с административной стороны, освоить новые формы поддержки исследований в организации и создать эффективную организационную культуру.

В данном тексте рассмотрим три ярких примера онлайн курсов от зарубежных библиотек и центров, которые посвящены обучению работе с данными.

Первый онлайн курс называется «Delivering Research Data Management Services». Данный курс разрабатывался Эдинбургским университетом, известным в сфере научной информации центом «Digital Curation Centre» и Центром научных исследований Нидерландов. Целью курса является обучение современных библиотекарей и научных администраторов принципам менеджмента данных для того, чтобы в дальнейшем они могли организовать правильные структуры по поддержке исследований в своих университетах или иных организациях.

Блоки этого курса состоят из небольших статей и коротких видео, основной объем составляют задания, которые подразумевают развернутые ответы и возможность участия в дискуссии в чате по обозначенной теме. Авторы курса считают, что таким образом участники кроме теории могут 
получить больше практических советов, полезных примеров того, как можно использовать и внедрять инициативы по управлению данными в стратегию своей организации. Однако, помимо стратегии и планирования, особенно ценным кажется и то, что авторы курса предлагают уже готовые советы по разработке тренингов по работе с данными для исследовательских коллективов и организации в целом.

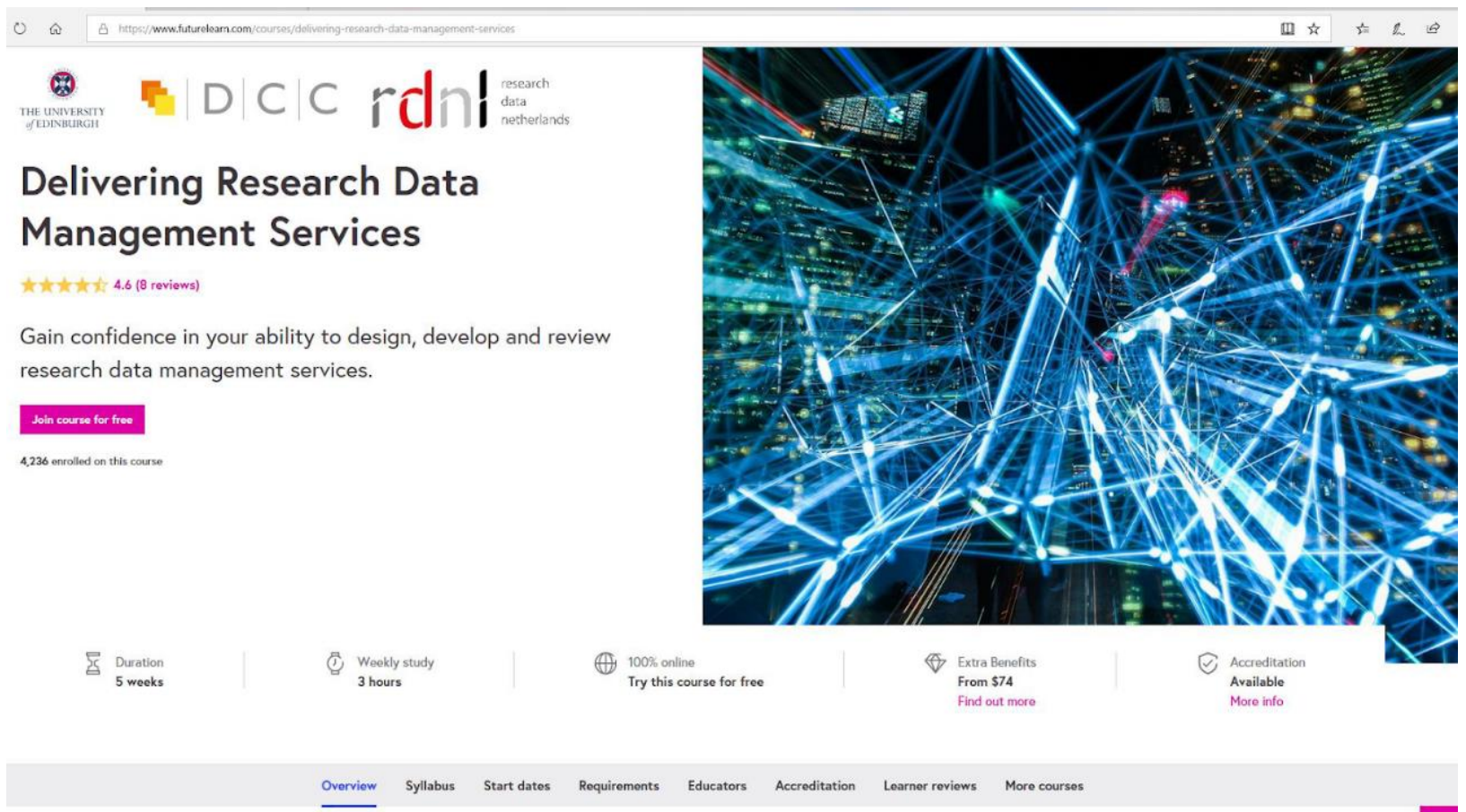

Pис. 1. Главная страница курса «Delivering Research Data Management Services» на платформе FutureLearn

Следующий курс «Research Data Management Librarian Academy (RDMLA)» также нацелен на профессиональное обучение библиотекарей, научных администраторов и других специалистов по информации навыкам управления данными. Разработчики курса - библиотекари, которые уже работают с данными в центрах поддержки исследований и готовы поделиться своим опытом. Программа данного курса, как и в предыдущем случае, фокусируется на необходимых знаниях в области менеджмента данных.

Курс состоит из восьми самостоятельных учебных программ, которые охватывают основы лицензирования исследовательских данных, советы 
и рекомендации по практике внедрения методов работы с данными в библиотеках и обзор инструментов для анализа данных. В отличии от предыдущего онлайн курса, в рамках данной программы в качестве заданий выступают проверочные тесты в конце блока или видеоурока. Для успешного прохождения онлайн курса не требуется слушать все восемь предложенных программ. В целом курс не предполагает дискуссии и обмена опытом между участниками и подходит тем, кому удобнее самостоятельно планировать свое обучение, выбирая именно те части, которые кажутся наиболее полезными.

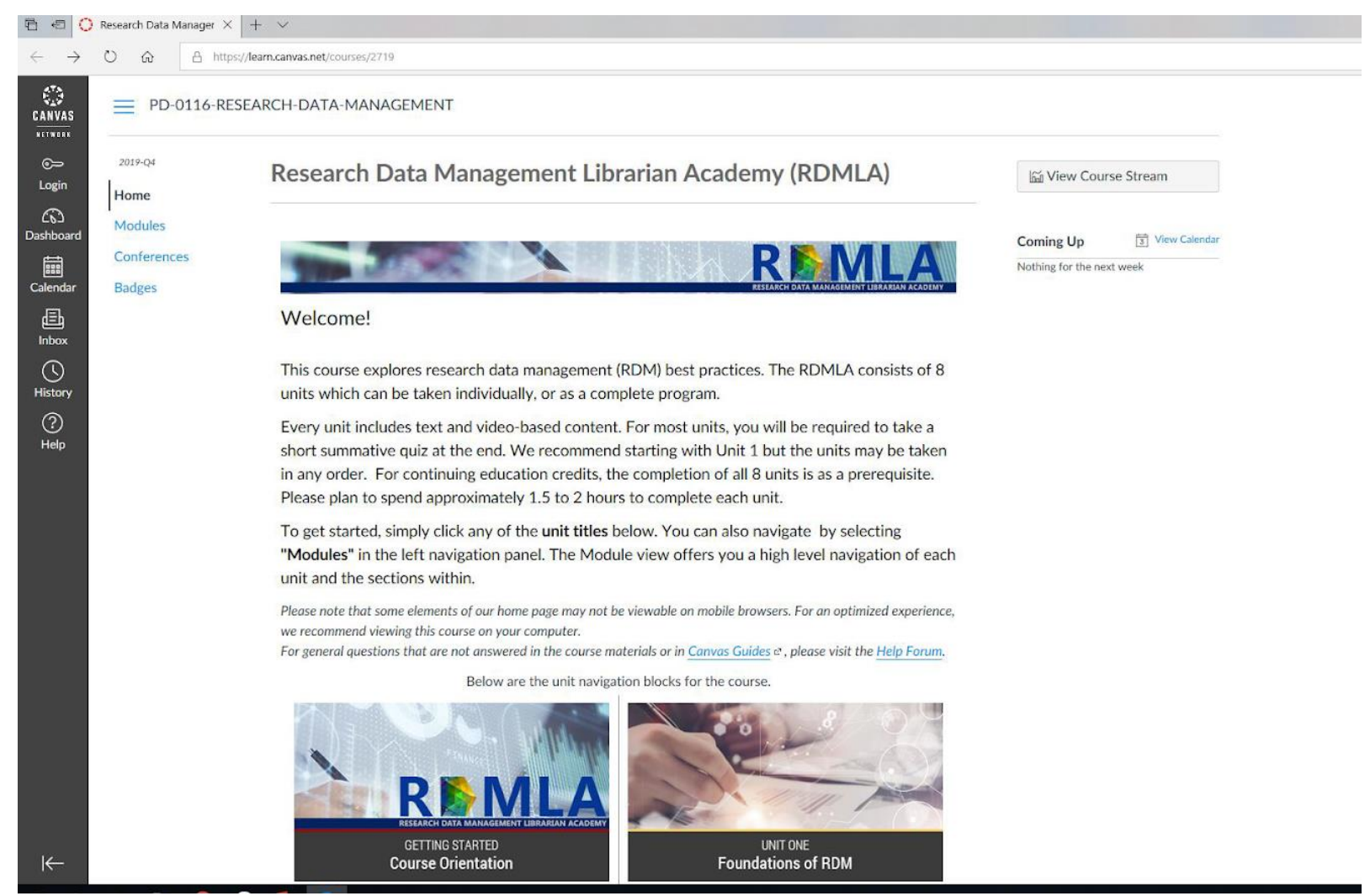

Puc. 2. Главная страница курса «Research Data Management Librarian Academy (RDMLA)» на платформе Canvas

Третий онлайн курс, который будет рассматриваться в данном тексте, называется «Research Data Management and Sharing». В отличии от предыдущих, этот курс предназначен для более широкой аудитории и может быть полезен как исследователям, студентам и преподавателям, так библиотекарям и научным администраторам. Сам курс нацелен не столько на развитие конкретных навыков управления данными, сколько 
на качественное объяснение того, что из себя представляют исследовательские данные и как выглядит цикл создания и использования данных. Помимо общей стратегической части, в рамках курса делается упор на объяснение принципов файлового менеджмента для тех, кто создает данные или пользуется готовыми данными из разных областей.

Подготовкой материалов для данного онлайн курса занимались ведущие центры поддержки данных, а также библиотеки Эдинбургского университета и университета Северной Каролины. Несмотря на то, что курс отличается от остальных по наполнению и целевой аудитории, структура учебной программы у всех курсов похожа. Занятия также проходят в формате видео, к каждому тематическому блоку прилагаются статьи и полезные ссылки, задания предполагают развернутый ответ по темам курса или тест. Письменные задания можно обсудить с другими слушателями и получить фидбэк. Такая практика обмена мнениями не просто приветствуется, но и порой предполагается организаторами курса как обязательная.

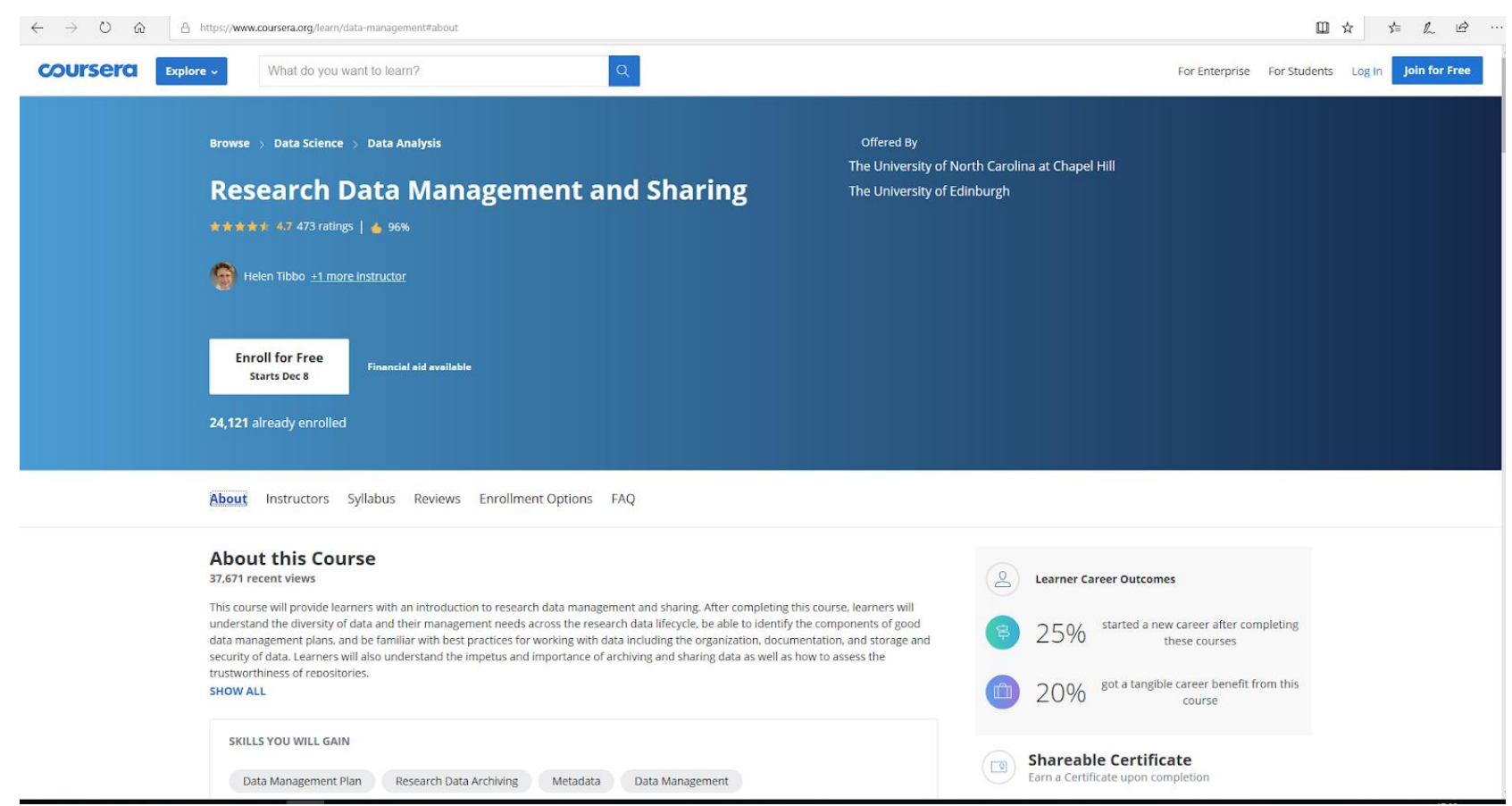

Pис. 3. Главная страница курса «Research Data Management and Sharing» на платформе Coursera 
Основные темы трех затронутых курсов вращаются вокруг одних и тех же областей, которые можно назвать фундаментальными в вопросах управления исследовательскими данными. Во-первых, во всех курсах упоминается цикличность процесса создания и использования данных. Традиционно авторы курсов выделяют, как минимум, пять этапов работы с данными: поиск, планирование, описание, архивирование и публикация. Далее в каждом курсе в зависимости от выбранной целевой аудитории детализируется тот или иной цикл работы с данными или способ организации работы с данными. Во-вторых, в каждом из трех курсов обсуждается тема планирования, поскольку создание продуманного и качественного плана является основой работы с данными, как для библиотекарей и научных администраторов, так и для исследователей. В-третьих, в качестве основной темы для рассмотрения вопроса менеджмента данных авторы курсов выбирают файловый менеджмент. На примере правильного наименования, хранения файлов авторы курсов помогают развивать навыки управления данными в рамках организации или даже небольшого исследовательского коллектива.

Однако, помимо готовых знаний по теме качественного управления данными от зарубежных коллег, для тех, кто заинтересован в продвижении темы, например, среди библиотекарей или научных администраторов, также найдется ниша, которую можно не просто занять, но и начать активно развивать. Вместо попыток охватить сразу все тонкости управления данными, изначально можно остановиться на двух простых и понятных пунктах: обучение работе с «готовыми» данными и обучение работе со «своими» данными для исследователей, преподавателей и студентов.

Для того, чтобы привить правильную культуру работы с «готовыми» данными, для начала можно просто подготовить общие встречи или лекции, посвященные плюсам использования вторичных данных в научных работах. Также помимо объяснения, зачем ученые сегодня могут использовать чужие 
данные, можно рассказать о том, где искать «готовые» данные. Для таких целей можно проводить тренинги по поиску в специальных поисковиках, которые аккумулируют данные по профессиональным областям, или в мета поисковиках, которые аккумулируют данных из репозиториев. Например, для исследователей, преподавателей и студентов можно рассказать о возможностях поиска в Mendeley Data или любой другой похожей базе данных. Если есть потребность охватить более конкретные области управления «готовыми» данными, можно подготовить ряд выступлений на тему хранения данных и правильного цитирования чужих данных в исследовательских и учебных работах.

Если в вашей организации есть сотрудники, которые сами генерируют исследовательские данные, то со стороны библиотекарей или научных администраторов не лишним будет проконсультировать их по созданию плана работы с исследовательскими данными, а также по вопросам файлового менеджмента, а именно, правильного именования файлов, созданию дополнительных и основных версий данных, безопасному хранению. Помимо прочего, можно проводить тренинги по стандартам создания метаданных: правильного документирования последовательности работы с данными и выбора необходимого формата описания собранных данных.

Для тех, кто хочет лучше разобраться в теме управления данными, приводим список полезных инструментов и материалов по работе с данными, взятых из учебных онлайн курсов ведущих зарубежных центров и библиотек:

\section{Репозитории данных:}

- $\quad \underline{E A S Y}$ (данные гуманитарных и социальных наук)

- $\quad$ 4TU.Centre for research data (данные технических наук)

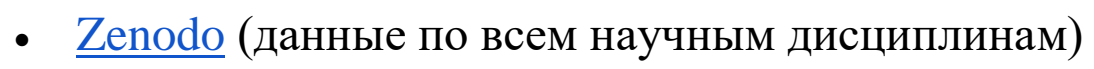

- $\quad$ Dryad (данные по всем научным дисциплинам)

- $\quad$ Mendeley Data (поисковик данных) 


\section{Центры по работе с данными:}

- Digital Curation Centre (DCC)

- Center for Research Libraries

- Research Data Netherlands

- The Research Data Alliance

Академические подразделения и библиотеки, работающие с данными:

- Research Data Service University of Edinburgh

- The TU Delft Library

- Research Data Service University of Glasgow

- LIBER

\section{Полезные инструменты:}

- Data Management Plans online

- MANTRA 
DOI: $10.33581 / 2020-20-51-55$

\section{ДИНАМИКА ПУБЛИКАЦИЙ РЕСПУБЛИКИ БЕЛАРУСЬ В SCOPUS. КОМПАРАТИВНЫЙ АНАЛИЗ \\ THE DYNAMICS OF PUBLICATIONS OF THE REPUBLIC OF BELARUS IN SCOPUS. COMPARATIVE ANALYSIS}

Гальнский Владимир Михайлович - канд. фриз.-мат. наук, дочент, заместитель начальника Управления международных связей Белорусского государственного университета (Беларусь), e-mail: galynsky@bsu.by.

Vladimir M Galynsky - Cand. Sci. (Phys.-Math.), Assoc. Prof., Deputy Head of the Department of International Relations, Belarusian State University (Belarus),e-mail: galynsky@bsu.by.

Аннотация: Подготовлен датасет публикаций по всем странам за 25 лет в наукометрической базе данных Scopиs, приведена статистика по Республике Беларусь, сделано сравнение с общеммровыми изифрами. Все заинтересованные, используя стандартный функционал табличного процеессора, могут самостоятельно создать фильтр и выборку информации из датасета, чтобы получить желаемые данные.

Abstract: A dataset of publications for all countries has been prepared for 25 years in the scientometric database Scopus, statistics for the Republic of Belarus are presented, a comparison with global figures is made. Anyone interested, using the standard functionality of the table processor, can independently create a filter and a selection of information from a dataset to get the desired data.

Ключевые слова: наукометрические базы данных, Scopиs, публикации.

Keywords: scientometric databases, Scopus, publications. 
Рассматривается статистика публикаций и цитирований по странам из базы данных Scopus, публикуемая на сайте «The SCImago Journal \& Country Rank» $\quad$ https://www.scimagojr.com/countryrank.php. Наукометрические данные для всех стран мира, показаны на сайте за последние 25 лет, с 1996 по 2019 годы. Для более удобного использования все цифры были собраны в датасет в виде нескольких таблиц в одном документе, размещенном в открытом доступе [1]. На отдельных страницах собрана суммарная информация по отдельным индикаторам по всем странам в динамике за 25 лет и суммарные цифры. Каждая вкладка (таблица) содержит название страны, число документов в базе данных Scopus, число процитированных документов, число цитирований, самоцитированний, среднее число цитированний на 1 документ, индекс Хирша. В созданном итоговом датасете построены дополнительные данные: ежегодный и суммарный рост числа публикаций в количественном выражении, в процентах. Датасет позволяет, используя стандартный функционал табличного процессора, создать фильтр, делать нужную выборку, сортировку. Такой формат позволяет любому заинтересованному самостоятельно получить и проанализировать интересующую информацию.

Статистика для Республики Беларусь показана в Таблице 1 и на Рисунке 1.

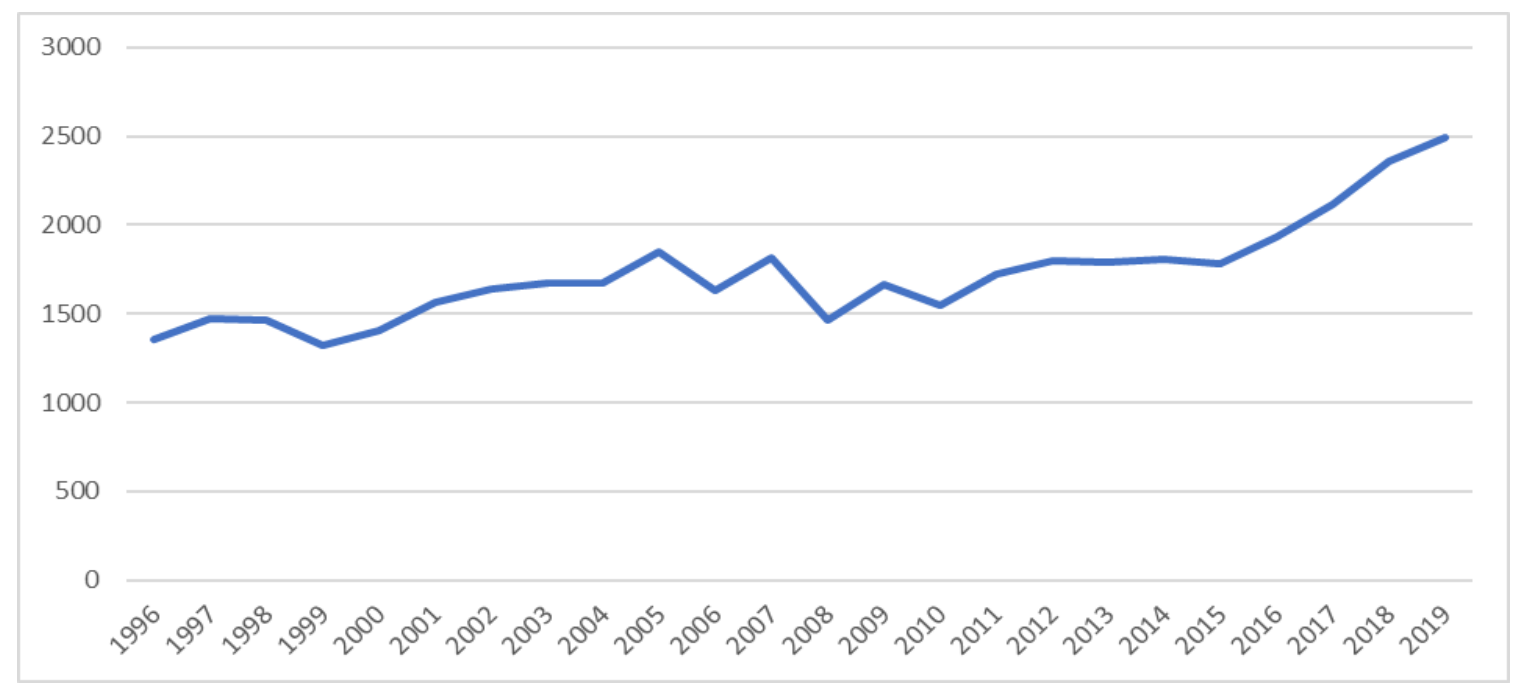

Рисунок 1. Число белорусских публикаций в наукометрической базе данных Scopus 
Таблица 1.

Число белорусских публикаций в наукометрической базе Scopus

\begin{tabular}{|c|c|c|c|c|c|}
\hline \multirow{2}{*}{$\begin{array}{c}\text { Календарный } \\
\text { год / база } \\
\text { данных }\end{array}$} & \multicolumn{5}{|c|}{$\begin{array}{c}\text { Данные по Республике Беларусь из базы данных Scopus, собрано на сайте } \\
\text { scimagojr.com }\end{array}$} \\
\hline & Публикаций & Цитирований & Самоцитирование & $\begin{array}{l}\text { Цитирование } \\
\text { на } 1 \text { документ }\end{array}$ & $\begin{array}{c}\text { Динамика } \\
\text { публикаций } \\
\text { к прошлому } \\
\text { году }\end{array}$ \\
\hline Всего & 41360 & 401105 & 73957 & 9,7 & - \\
\hline 1996 & 1359 & 9248 & 1936 & 6,81 & - \\
\hline 1997 & 1475 & 11839 & 2395 & 8,03 & $9 \%$ \\
\hline 1998 & 1464 & 12336 & 2306 & 8,43 & $-1 \%$ \\
\hline 1999 & 1321 & 14946 & 2453 & 11,31 & $-10 \%$ \\
\hline 2000 & 1405 & 15537 & 2488 & 11,06 & $6 \%$ \\
\hline 2001 & 1564 & 19218 & 2436 & 12,29 & $11 \%$ \\
\hline 2002 & 1643 & 17117 & 2784 & 10,42 & $5 \%$ \\
\hline 2003 & 1675 & 15462 & 2840 & 9,23 & $2 \%$ \\
\hline 2004 & 1676 & 18398 & 3048 & 10,98 & $0 \%$ \\
\hline 2005 & 1848 & 16752 & 2828 & 9,06 & $10 \%$ \\
\hline 2006 & 1633 & 18050 & 2583 & 11,05 & $-12 \%$ \\
\hline 2007 & 1815 & 16246 & 2524 & 8,95 & $11 \%$ \\
\hline 2008 & 1466 & 22831 & 3879 & 15,57 & $-19 \%$ \\
\hline 2009 & 1664 & 14646 & 2500 & 15,57 & $14 \%$ \\
\hline 2010 & 1544 & 18218 & 3862 & 11,8 & $-7 \%$ \\
\hline 2011 & 1726 & 18977 & 4486 & 10,99 & $12 \%$ \\
\hline 2012 & 1795 & 33472 & 5383 & 18,65 & $4 \%$ \\
\hline 2013 & 1787 & 22480 & 4755 & 12,58 & $0 \%$ \\
\hline 2014 & 1811 & 17938 & 4143 & 9,91 & $1 \%$ \\
\hline 2015 & 1781 & 19967 & 4206 & 11,21 & $-2 \%$ \\
\hline 2016 & 1936 & 21511 & 4150 & 11,11 & $9 \%$ \\
\hline 2017 & 2120 & 13761 & 3656 & 6,49 & $10 \%$ \\
\hline 2018 & 2363 & 10260 & 1953 & 4,34 & $11 \%$ \\
\hline 2019 & 2489 & 1895 & 363 & 0,76 & $5 \%$ \\
\hline
\end{tabular}


Общее число публикаций за весь рассматриваемый период в Беларуси выросло в 1,8 раза, в то время как в общемировых цифрах динамика равна 2,75. Если рассмотреть подробно число публикаций в мире по годам, то можно выделить 2 области бурного роста: в 2000-2013 гг и после 2017 (Рисунок 2). Сравнивая графики на рисунках 1 и 2 следует отметить, что в первый период роста число публикаций в Беларусь оставалось стабильным, лихорадка «publish or perish» (английская идиома, которую можно перевести как «опубликуйся или умри» или «опубликоваться любой ценой»), которая охватила весь мир [2], нашей страны не коснулась. Но во втором периоде роста дианмика публикаций присутствует.

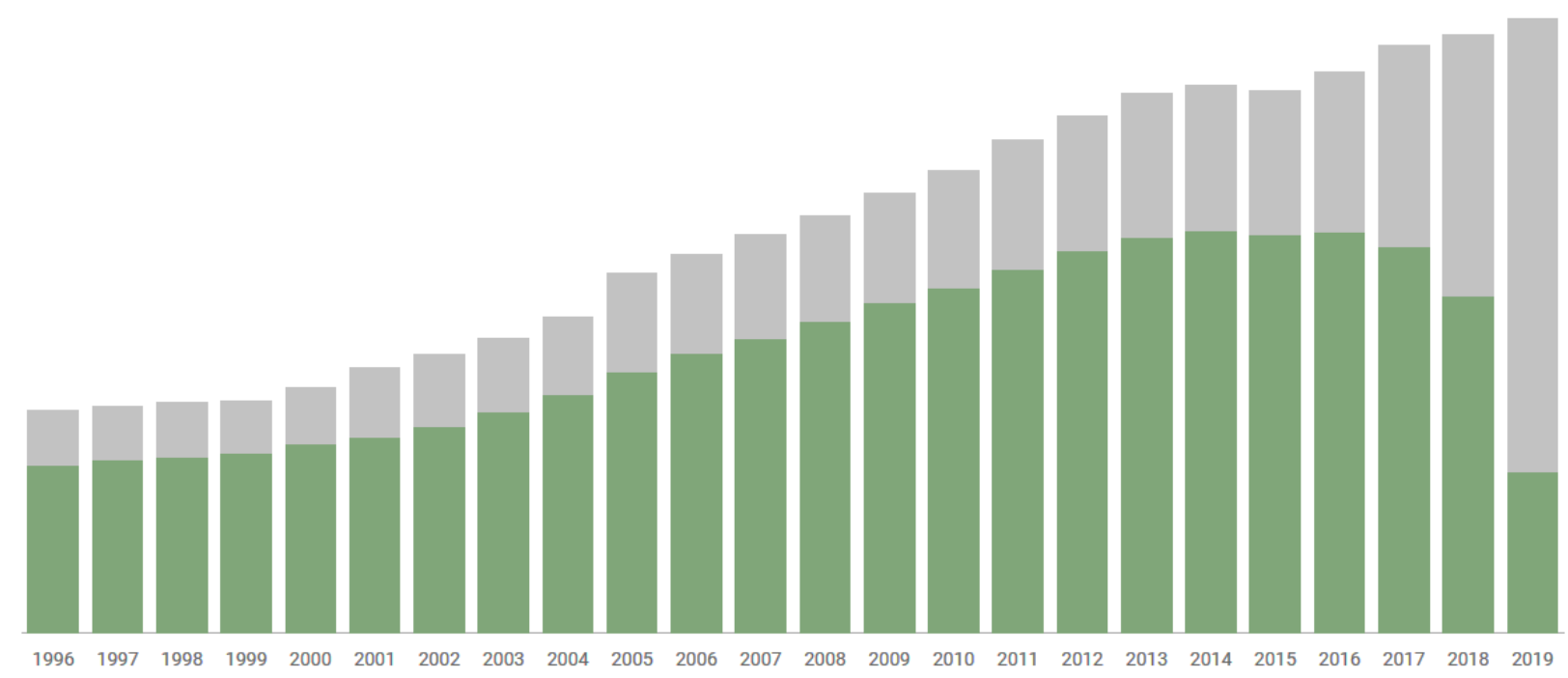

Рисунок 2. Число всех публикаций в наукометрической базе данных Scopus

Если сравнивать с другими странами, то рост за 25 лет в 1,8 раза характерен для Японии, США, Великобритании. Для стран СНГ характерно более динамичное поведение, что связано с тем, что постепенно увеличивается потребность в «скопусовских публикациях», в силу реализации программ повышения конкурентоспособности систем образования и конкретных университетов, поскольку число и качество таких публикаций является ключевым моментом для всех традиционных 
рейтингов. Число публикаций в Scopus используется как индикатор в:

- рейтинге «Глобальный индекс инноваций» (The Global Innovation Index), в котором участвует страна;

- глобальных и предметных рейтингах университетов, как в явном виде, так и в виде наукометрических данных;

- конкурсах для получение научного финансирования;

- анализе результатов исследований отдельных ученых, учреждений и стран.

\section{СПИСОК ИСТОЧНИКОВ}

1. Галынский, В. М. Статистика показателей Scimagojr country rank за 1996-2019 годы (Датасет) [Электронный ресурс] / В. М. Галынский // Электронная библиотека БГУ. Минск, 2020. - Режим доступа: https://elib.bsu.by/handle/123456789/250926. - Дата доступа: 12.12.2020.

2. Kun, Á. Publish and who should perish: you or science? [Electronic resource] // Publications. - 2018. - Vol. 6, iss. 2. - Mode of access: https://www.mdpi.com/23046775/6/2/18/htm. - Date of access: 21.03.2021. 
DOI: $10.33581 / 2020-20-56-64$

\section{DSPACЕ - ОПЫТ САМОСТОЯТЕЛЬНОГО АУДИТА И ОБНОВЛЕНИЯ СЕРВИСА С НЕБОЛЬШОЙ ВНЕШНЕЙ ПОДДЕРЖКОЙ}

\section{DSPACE - EXPERIENCE OF SELF-AUDITING AND SERVICE UPDATES WITH LITTLE EXTERNAL SUPPORT}

Ефимов Александр Александрович - заместитель начальника отдела информационно-аналитического сопровождения Уральского федерального университета (Россия), e-mail: alexander.efimov@urfu.ru

Efimov Alexander - deputy of head, Department of information and analytical support, Ural Federal University (Russian Federation), e-mail: alexander.efimov@urfu.ru

Аннотация: В статье описывается опыт обновления Электронной библиотеки Белорусского государственного технологического университета (БГТУ), произведенный собственными силами сотрудников БГТУ с методической поддержкой внешнего эксперта. Процесс обновления разделен на этапь, включающие в себя аудит сервиса, устранение проблем, обнаруженных в проиессе аудита, планирование обновления, непосредственно обновление, фиксацию результатов, создание отчета.

Abstract: The author describes the experience of updating the institutional repository of BSTU. The update was carried out by the university staff with a little support from an external expert. The upgrade process is divided into stages such as audit, problem solving, upgrade planning, upgrade, report generation.

Ключевые слова: DSpace, обновление DSpace, аудит, качество контента, качество метаданных, тайм-менеджмент, работа в команде.

Keywords: DSpace, upgrading DSpace, audit, content quality, metadata quality, time managemen, team management. 
DSpace - это открытое, свободное кроссплатформенное приложение для создания институционального репозитория. Подразумевая долгосрочное накопление и хранение информации в такой консервативной организации как университет, мы автоматически получаем достаточно консервативный сервис, отражающий научную, публикационную и иные активности университета. При этом, не смотря на понятные требования стабильности, преемственности, защищённости и пр. к сервису также предъявляются требования и по актуальности механизмов агрегирования контента, удобству редактирования данных и метаданных, эффективному представлению данных и метаданных. Всё это вызывает необходимость время от времени пересматривать методики работы с сервисом, проводить обновление как сервисного программного обеспечения, так и операционной системы, проводить аудит контента.

Несмотря на наличие отличной документации на английском языке и очень дружного интернационального сообщества пользователей, порой трудно реализовывать данные задачи полностью самостоятельно и в рабочем порядке, да еще и с минимальными простоями сервиса или вовсе без них. Данная статья описывает успешный опыт реализации описанных выше задач, который позволил сотрудникам, поддерживающим репозиторий, приобрести необходимые навыки, обнаружить проблемы, нуждающиеся в исправлении, уточнить методику для разных категорий пользователей, лучше понять и документировать сервис.

Описание процесса разделено на три больших части, каждая из которых, в свою очередь, разделена на этапы. Части и этапы определены не формально, что лучше отражает суть. 


\section{Часть первая - общение с человеком}

\section{1. Анализ и формализация ощущений эксплуатанта о текущем}

\section{состоянии сервиса}

Обычно эксплуатант может указать на реальные проблемы, но не может верно определить их источник. Тут помогает и собственный опыт эксперта и дополнительное общение с эксплуатантом. А когда оказывается, что проблемы в общем понятны и как их решать - тоже понятно, у всех добавляется уверенности. На самом деле, показать ошибки, связанные как с контентом, так и с проблемами безопасности, можно на примере любого репозитория. Но к счастью, показать способ устранения ошибки, обычно также легко и быстро, как и указать на ошибку.

2. Анализ и формализация ожиданий эксплуатанта от сервиса

\section{в результате аудита и обновления}

Обычно эксплуатанты не знают о новых возможностях абстрактной новой версии ПО, но знакомы с опытом коллег. И если у кого-то что-то работает, и если оно работает хорошо - рано или поздно, такой опыт распространяется на всё сообщество. На этом этапе полезно объяснить эксплуатанту о ключевых новых функциях новых версий, о закрытии уязвимостей и пр. Это может повлиять в дальнейшем на методику использования сервиса и сделать сервис более полезным, а его работу более эффективной.

B целом, коллеги, использующие DSpace, частенько игнорируют регулярное извлечение полных текстов (улучшает поиск), обновление OAI фида (обеспечивает отражение в большинстве отраслевых агрегаторов), обновление sitemap (обеспечивает индексацию в поисковых системах). Также, не редки недостоверные handle prefix и некоторые другие базовые настройки. Причем такое положение вещей обычно наблюдается с момента установки сервиса, т.е. всё время его работы. Важно отметить, что сказанное выше не относится к БГТУ, это скорее обобщённая картина. 
Часто эксплуатант предлагает просто настроить сервис по результатам аудита и ничего не обновлять, но опыт работы с БГТУ подарил хороший пример необходимости обновления. Команда dspace oai import -f на верно настроенном DSpace 6.0 выполнялась около десяти часов, а на DSpace 6.3 на том же объёме фонда - около десяти минут.

3. Уточнение компетенций сотрудников (администраторов, контент-менеджеров, бюрократов) на стороне эксплуатанта, формальное распределение ролей и зон ответственности

Всегда есть «местный админ», «общий админ», «контент-менеджер», «бюрократ» и некоторые другие сотрудники, отвечающие за свои части работы сервиса. Работа со всеми должна быть прозрачна. Именно эти люди берут на себя значительную часть взаимодействия с внутренними службами (IT, PR, Library, etc.) и извне на это не повлиять, поэтому каждый должен быть компетентен и понимать свои задачи, свою ответственность. Также здесь очень важны доверительные человеческие отношения. Но при взаимодействии в некоммерческом формате именно так и бывает. Иначе просто не получается взаимодействие.

\section{4. Создание эффективных каналов связи}

Не трудно подобрать такой мессенджер, который будет удобен для общения как в группе, так и личном, передаче файлов, скриншотов, документов и пр. Проблема может возникнуть только в желании или нежелании общаться. Но, как показывает опыт, если дело дошло до обновления, то все достаточно мотивированы и могут и будут говорить, обсуждать и пр.

\section{Часть вторая - общение с компьютером}

1. Создание тестовой зоны (одной или нескольких) для проверок и тестов без простоя сервиса

В случае с БГТУ процесс был основан на доверии. Копия (обезличеннаяи без персональных данных) виртуальной машины была 
развернута как на мощностях «внешнего консультанта», так и на мощностях ВУЗа. Все подготовительные и тестовые операции проводились на тестовых зонах, обсуждались, делались выводы. Виртуализация в целом, и возможность создать достаточное количество копий, и раздать их всем заинтересованным (в частности), очень сильно развязывает руки и повышает удобство.

2. По результатам аудита: создание списка проблем, которые могут (должны) быть устранены без значительного простоя и до обновления сервиса

Обычно в процессе аудита продуктивного сервиса и различных операций на тестовой зоне появляется список задач, которые необходимо реализовать быстро, т.к. временные штрафы при их устранении велики. Например, исправить недостоверный robots.txt, исправить или просто создать достоверный sitemap, проверить и (при необходимости) исправить какие-то настройки сервиса, влияющие на безопасность (доступный извне solr, например), или адекватную работу сервиса (недостоверный handle prefix). Даже если дальнейшие работы по обновлению не будут проведены, либо будут запланированы на более позднее время, есть такие вещи, которые нужно исправлять здесь и сейчас, т.е. до или независимо от обновления.

3. По результатам аудита: создание списка проблем, которые будут решаться после обновления сервиса в рабочем порядке

Данный момент субъективен, но как показывает практика, чем актуальнее версия DSpace, тем лучше работает извлечение полных текстов, тем быстрее работает обновление индексов solr и пр. Конечно, провести многие (по сути регламентные) процедуры можно и до обновления, но после обновления их снова придётся проводить (с ключом -f), затирая прошлые результаты. Что касается правки (пакетной) метаданных на частые ошибки (такие, как двойные пробелы, пробелы перед запятыми, латинские символы в инициалах авторов с «русскими» фамилиями и пр.) - этот процесс 
можно делать всегда... и ошибки будут всегда. Старые исправятся, новые появятся. Процесс этот бесконечный, но и в нём нужна системность.

\section{4. Построение плана обновления сервиса, тестовое обновление}

\section{на тестовой зоне, анализ}

Сама по себе процедура обновления DSpace достаточно проста. Она описана на WIKI ресурсе производителя, в сети также есть алтернативные текстовые и видео-инструкции по обновлению. Сам по себе процесс не сложен, но, это если устанавливался сервис по каким-то правилам, человек, устанавливавший сервис, доступен, и нет никаких проблем или неизвестных.

В БГТУ обновлению сервиса предшествовало обновление операционной системы. Были рассмотрены: вариант с переносом сервиса в виртуальную машину с новой версией ОС, и последующее обновление; и обновление ОС с установленным сервисом. В какой-то момент времени у «внешнего консультанта» было пять экземпляров сервиса в пяти виртуальных машинах. Учитывая положение вещей и ресурсы на месте, было принято решение обновлять ОС с сервисом, «чистить» ОС после обновления, настраивать ротацию логов и пр. и только потом обновлять сервис. Вопрос о том, оптимально ли это решение, не стоит. Факт в том, что решение реализовано, операционная система, установленная в виртуальной машине, поддерживается и получает обновления, сервис обновлён и работает так, как ожидается. Да, «внешний консультант» что-то бы сделал иначе, но специалисты БГТУ, исходя из своих возможностей выбрали другой вариант и реализовали его.

Относительно мягкие установленные сроки позволяли документировать каждый шаг, записывать действия на видео, пробовать, повторять, обсуждать. Напомню, речь идет об обновлении тестовой зоны. 


\section{5. Формализация опыта обновления тестовой зоны, уточнение}

\section{плана обновления, выводы}

Опыт обновления тестовой зоны максимально приближен к процессу обновления боевого сервиса. В случае с БГТУ разница была лишь в точке публикации. Процесс был описан, выводы сделаны, опыт формализовался в сценарий для обновления боевого сервиса. Сотрудники БГТУ, участвовавшие в реализации задачи, сами понимали все этапы процесса обновления, понимали кто и что будет делать перед обновлением боевого сервиса, во время обновления, и после. «Внешний консультант» же был на подхвате.

\section{Часть третья - реализация обновления}

\section{1. Создание резервной копии}

В данном случае проблема резервного копирования решилась посредством создания копии виртуальной машины. Как перед обновлением прикладного программного обеспечения и операционной системы, так и перед обновлением сервиса.

\section{2. Собственно, обновление}

Всё прошло так, как задумывалось. А именно, сервис и ОС были не только обновлены с минимальным временем простоя, но были обновлены своими силами без привлечения помощи извне. Команда, поддерживающая репозиторий, понимала каждый этап реализации процесса обновления и каждый этап реализовала. В принципе, всё прошло так, как и планировалось, а «Внешний консультант» был привлечен лишь для того, чтобы констатировать отсутствие проблем после обновления.

Вообще, это самое замечательное, когда в процессе реализации какой-то задачи, не только реализуется сама задача, но и команда, задачу реализовавшая, получает опыт, достаточный для последующего тиражирования технологии. 


\section{3. Проверка работы агрегаторов, интеграции с системами}

\section{мониторинга и поисковыми системами}

DSpace - платформа синдикатная. Обычно регистрация во всяческих агрегаторах либо была сделана на старте работы сервиса, либо не была сделана вовсе, а обновленный сервис (без ошибок в OAI, sitemap, robots.txt, c включенным https и пр.) - это хороший повод проверить интеграцию

с агрегаторами, поисковыми системами и пр. Опыт БГТУ показал, что проблемы конечно есть, но также было показано, что неразрешимых проблем нет. Теперь всё работает так, как ожидается. Каждый шаг описан, каждый шаг понятен.

\section{4. Проверка нового функционала}

Здесь имеется ввиду не столько новый функционал ПО, сколько функционал, который ранее не использовался эксплуатантом: автоматический запуск некоторых регламентных процедур, использование инструментов, которые ранее не использовались и пр. Это может быть как банальная автоматическая регулярная генерация sitemap, так и достаточно тонкая настройка потребления памяти сервисами solr или СУБД. Этот момент, в общем, всё еще пусконаладочный, и его не всегда получается полностью проверить на тестовой зоне, т.к. она банально может быть запущена на ином гипервизоре с иным пулом ресурсов.

5. Формализация опыта обновления боевой зоны, уточнение плана

\section{обновления, выводы}

В случае с БГТУ, насколько мне известно, всё прошло штатно и серьезных изменений в выводах к обновлению тестовой зоны не было. Была проведена дополнительная работа по настройке точки публикации, но это уже специфика реализации точек публикации веб-ресурсов в конкретной организации. А ваш репозиторий опубликован по https? А какой http-proxy вы используете? А в логах вашего Tomcat реальный адрес клиента? А каков максимальный размер post/get запроса у вашего сервиса? 
Bсе вопросы с подвохом, а в БГТУ всё так, как надо, но, «внешний консультант» реализовал бы иначе.

6. Возврат к списку проблем, устранение которых было решено провести в рабочем порядке после обновления сервиса

Насколько мне известно, коллеги и до обновления репозитория понимали, какой объём работ нужно выполнить для того, чтобы контент репозитория был более репрезентативен, а в процессе это понимание только улучшилось. Работа по редактированию метаданных ведется, внесены изменения в методику работы контент-менеджеров, которые позволяют исключить риски появления некоторых типов ошибок, выполняются проверки. Система работает.

\section{Заключение}

В заключении мне хотелось бы поблагодарить коллег. За мотивацию, за компетентность, за профессионализм, за доверие. И пожелать коллегам успехов. 
DOI: $10.33581 / 2020-20-65-71$

\section{КАДРЫ БИБЛИОТЕКИ СОВРЕМЕННОГО УНИВЕРСИТЕТА: ОТВЕТИТЬ НА ВЫЗОВЫ ВРЕМЕНИ THE MODERN UNIVERSITY LIBRARY'S CADRES: TO ANSWER THE CHALLENGES OF THE TIME}

Лопатина Наталья Викторовна - заведующий кафедрой библиотечноинформационных наук Московского государственного института культуры (Россия), e-mail: lis.mgik@yandex.ru

Lopatina Natalia Viktorovna - Moscow State Institute of Culture, Head of the Library and Information Sciences Department (Russian Federation), e-mail: lis.mgik@yandex.ru

Аннотация. В докладе проектируется компетентностная модель специалиста университетской библиотеки. Профессиональнье u личностностные компетенциии моделируются в русле идеологии прикладной информатики как особого научно-практического направления. Рассматриваются проблемы подготовки спещуиалистов для университетской библиотеки. Особое внимание уделяется динамике компетентностных требований $к$ сотрудникам вузовских библиотек в условиях цүифровой трансформацчи образования.

Annotation. The report projects the competence model of a university library specialist. The professional and personal competencies are modeled with the applied informatics ideology as a special scientific and practical direction. The problems of training specialists for the university libraries are considered. A special attention is paid to the dynamics of the competence requirements for the university libraries' staff in the context of digital transformation of education. 
Ключевые слова: библиотека, цицрровизация, высшее образование, университетская библиотека, библиотекарь, прикладная информатика.

Keywords: library, digitalization, higher education, university library, librarian, applied computer science.

Библиотечные специалисты - один из базовых параметров современной информационной сферы. Уровень их компетенции выступает одним из важнейших критериев и показателей готовности социума к эффективному реагированию на цифровые трансформации. Библиотечные специалисты включены в кадровый потенциал цифровой экономики, который выступает условием эффективности её построения, а также условием развития науки, техники, воспроизводства человеческого капитала. Кадры университетских библиотек играют в этом процессе ключевую роль.

Что должно лежать в основе компетентностного проектирования? Опыт прошедших десятилетий учит нас работать на опережение, реагировать не на тренды и бренды информационного рынка целевых ориентиров, которые изменяются реже, чем арсенал инструментов решения профессиональных задач. Компетентностная модель библиотечного специалиста должна опираться на широкую трактовку цифрового развития как глобальной тенденции к изменению структуры и функционирования социальных систем и институтов под воздействием новой идеологии информационного оперирования.

Компетентностное проектирование «университетского библиотекаря» определяют цифровые трансформации образования как социального института. В данном случае речь идет уже не только об отдельных «скачках» (внедрении цифровых ресурсов и сервисов расчета книгообеспеченности; создании собственных электронных коллекций, обеспечении легитимного доступа к внешним ресурсам, поддержке публикационной активности ППС и visibility опубликованных работ), но о системных сдвигах: о новом дизайне 
образовательной среды, в котором цифровые ресурсы играют не менее значимую роль, чем педагог. В 1990-2000-е годы демократизация образовательного процесса, начальные этапы информатизации, неготовность образовательного контента в электронных форматах закрепили приоритет за педагогом и человеком, отодвинув на второй план работу с информационными ресурсами. В 2020 году на новом витке спирали наблюдается возвращение к традиционным педагогическим методологиям, в которых особое значение принадлежит самостоятельной работе обучающихся с источниками: учебной литературой, первоисточниками, монографическими неадаптированными работами, актуальными публикациями в научной и профессиональной периодике.

Дистанционный формат и на уровне официальных образовательных систем, и на обывательском уровне, и на уровне самих учебных заведений продолжал восприниматься как эрзац, суррогат. 2020 год мобилизовал имеющиеся ресурсы и возможности для масштабной виртуализации высшего образования и показал, во-первых, множество готовых универсальных ИТ-решения, легко адаптируемых к нуждам образовательного процесса; во-вторых, готовность большей части педагогов к трансляции потокового видео, коллаборации, работе с документными массивами образовательной и профессиональной направленности; в-третьих, масштабы и характер кумуляции цифрового контента, его доступность для массового пользователя и разнообразие.

Сегодняшняя библиотека университета ориентирована не только на обслуживание, но более - на создание комплексного инструментария, сфокусированного на решении задач личностно-профессионального развития студента посредством организации его информационной, познавательной работы. Выстраивается роль библиотекаря в модерировании коллабарации педагогов одной специальности (но разной корпоративной, ведомственной принадлежности, гражданства). В основе этого инструментария лежит особая 
метаинформационная (в философском, а не только прикладном понимании этого слова), отчасти библиографическая «надстройка» - c единой телеологией, с единой стратегической направленностью, с плюрализмом и академическими свободами, с учётом информационной культуры нашей читательской аудитории.

Именно эти трансформации определяют и системные изменения профессии университетского библиотекаря: и функций, и структуры профессионального пространства, и компетентностного содержания.

Во-первых, встает вопрос о зоне действия педагога и о зоне действия библиотекаря: сегодня очень сложно провести демаркационную линию между инструментарием педагогическим и метаинформационным, ибо речь идет об усилении информационно-библиографического компонента в профессии педагога и о процессах конвергенции профессиональной деятельности педагога и библиотекаря. Изменяется статус средообразующей функции педагога, которая ранее носила латентный характер: педагог осознанно создает в цифровом пространстве соответствующий комплекс информационных условий, «продвигает» профессиональные концепции, смыслы, взгляды, решения с помощью ненавязчивой рекомендации конкретного автора, конкретного ресурса посредством традиционных библиотечно-информационных инструментов:

рекомендательнобиблиографических характеристик, социально-информационных технологий и т.Д.

Решение этого вопроса позволит определить целесообразность появления новых профессий: библиотекарь-тьютор, библиотекарьпредметник, цифровой куратор и т.п.

Во-вторых, цифровое развитие будет и далее стимулировать информатизацию профессиональной структуры общества, в первую очередь, усиление информационного компонента, проникновение информационных функций в компетентностное содержание устоявшихся профессий. 
И педагог, и студент, и вузовский менеджер овладевают теми цифровыми компетенциями, которые ранее были привилегией вузовского библиотекаря. Решение целого ряда задач решается в режиме информационного самообслуживания, в том числе наблюдается не просто ускорение диффузии цтфровых компетенций, но и формируется опыт самостоятельного овладения новыми информационными инструментами, вне «цифрового кураторства» (тренингов, консультаций). В этом есть определенные риски, определенная уязвимость для университетского библиотекаря, упредить и преодолеть которые можно только профессионализмом, усилением hard skills, которые выступают идентификационным признаком нашей профессии. В первую очередь, библиотечно-технологические знания, умения, навыки; «отраслевое» знание «обслуживаемой» сферы деятельности; готовность к управлению производственными процессами в информационной сфере; цифровые компетенции на уровне «профессионального пользователя»; способность к созданию новых инструментов профессиональной библиотечной деятельности. Целесообразно строить компетентностное проектирование университетского библиотекаря в русле прикладной информатики: комплекс его профессиональных действий требует понимания процессов, механизмов, отношений, инструментов высшего образования; готовности поставить и решить цифровыми инструментами любую профессиональную задачу, зная ее суть.

В-третьих, необходимо рационально использовать компетенции университетского библиотекаря в создании цифрового контента. Перед университетскими библиотеками встает новая задача: особое дидактически ориентированное представление смыслов, текстов, взаимодействий; изменение содержания составляющих высшего образования и информационной сферы, в смещении акцентов в сторону одного из важнейших приоритетов цифрового мира - в сторону интеллектуализации, которая требует информационно-аналитических компетенций, компетенций 
в области проектирования, дизайна знаний. Создание цифрового образовательного контента требует библиотечных hard skills: знаний информационно-аналитической природы, знаний в области психологии чтения, в области типологии читателей, в области информационного поведения и информационной культуры.

В-четвертых, университеты выходят за рамки средового подхода в педагогике высшей школы, и новые компетенции библиотекаря ориентированы на информационную инфраструктуру современного глобального социума, которая представляет собой совокупность информационных каналов, сред, технологий и информационных ресурсов. Говорим именно о совокупности, о конгломерате, имеющем тенденцию к взаимодействию вне процессов системной интеграции. А вот имитировать эту интеграцию, имитировать единое цифровое пространство знания, в котором оно не распадается на дискретные кусочки, на мозаику ресурсов, призвана именно университетская библиотека посредством интеллекта, умений, способностей своих сотрудников.

Новые цифровые технологии выводят образовательный процесс за стены аудиторий и зоны вещания педагога, за рамки имеющего в библиотеке массива информационных ресурсов, делая образовательное пространство поистине безграничным. Изобилие информационных ресурсов требует тщательно продуманных приемов их систематизации и представления для студента. И самое основное - приемов их отбора, определения их потенциала для педагогического процесса, для педагогической реализации. На сегодняшний день задача доступности ресурсов уже решена, но обозримость массива, его эффективная структурируемость требует критических решений. В контексте университетских библиотек принципиальным условием комфортности образовательной информационной среды выступает адаптация научного и профессионального знания к учебному процессу. 
Новые компетенции университетского библиотекаря являются отражением векторов информационного развития, демонстрируют новые функции профессионального пространства, вхождение его в новые системы социальных отношений. В настоящее время речь идёт о предсинтезе нового кластера профессиональных компетенций библиотекаря. Данный компетентностный комплекс не сформировался как системная целостность. Но на сегодняшний день ключевой его позицией выступает готовность современных библиотекарей работать в условиях динамично развивающейся профессиональной среды. 
DOI: $10.33581 / 2020-20-72-76$

\section{МММ-СПЕЦИАЛИСТ = СОВРЕМЕННЫЙ БИБЛИОТЕКАРЬ SMM SPECIALIST = MODERN LIBRARIAN}

Гавдей Анастасия Николаевна - библиотекарь II категории научнометодического отдела Фундаментальной библиотеки Белорусского государственного университета (Беларусь), е-таil: haudzei@bsu.by

Haudzei Anastasiya - librarian of the II category Scientific-methodical Department of the Fundamental library of the Belarusian State University (Belarus), e-mail: haudzei@bsu.by

Аннотация: В докладе рассказывается о профессии SММ-специалиста, его навыках и умениях, а также требованиях, предъявляемых к данной профессии. Ключевым аспектом статьи является применение принципов работы SMM-специалиста для библиотечных кадров, занимающихся социиальными сетями.

Abstract: The report tells about the profession of an SMM specialist, his skills and abilities, as well as the requirements for this profession. A key aspect of the article is the application of the principles of the SMM specialist to the library staff involved in social networks.

Ключевые слова: SMM, SMM-специалисты, м медиамаркетинг, сочичальные сети, аккаунты, библиотечное дело, библиотечное обслуживание, библиотеки, библиотечный SMM.

Keywords: SMM, SMM-specialists, media marketing, social networks, accounts, librarianship, library service, libraries, library SMM. 
Еще совсем недавно велись разговоры о цифровом будущем. Но доступность и распространенность интернета лишний раз подтверждает, что мы уже живем в цифровом мире, ведь сегодня каждый житель планеты пользуется услугами сети. Самой динамически развивающей средой можно назвать социальные сети. Такая популярность во всем мире делает их очень привлекательными площадками для рекламы продуктов и услуг. В связи с этим возникает потребность в специалистах, которые могут заниматься маркетингом в социальных сетях.

Давайте разберемся, что же такое маркетинг в социальных сетях или SMM (Social Media Marketing) - это комплекс действий нацеленый на взаимодействие с людьми через социальные сети. SMM помогает донести до пользователей, в том числе потенциальных, информацию о товарах или услугах организации с помощью рекламы [8].

Исходя из этого можно дать определение SMM-специалисту это специалист, занимающийся развитием аккаунта (страницы, группы или сообщества) в социальных сетях, и отвечающий за привлечение подписчиков, общение с ними и формирование положительных ассоциаций об организации, ее продуктах и услугах. Основной задачей такого специалиста является ненавязчивое направление потенциальных пользователей на выполнение необходимого для организации целевого действия.

Профессия «SММ-специалист» - это профессия 21 века. Далеко не каждый может представить, на что он способен, что входит в его обязанности и какие требования к нему предъявляются.

Основными обязанностями SMM-специалиста являются следующие:

1. Анализ страниц конкурентов и целевой аудитории.

2. Разработка, создание контента, а также оформление единого стиля страницы для продвижения её в социальных сетях (написание текстов, создание фото, логотипа, видео и т.д.). 
3. Создание, ведение и развитие пабликов / профилей / официальных страниц в социальных сетях - VK, Instagram, Facebook, Twitter, OK, YouTube и др. (набор социальных сетей может меняться в зависимости от целевой аудитории).

4. Привлечение, а также увеличение числа подписчиков и посетителей.

5. Ведение диалога с подписчиками, отслеживание их действий и интересов.

6. Запуск активностей - проведение игр, конкурсов, опросов по интересам, различных викторин и прочее.

7. Ведение отчётности.

При приёме на работу SMM-специалиста к нему предъявляются определённые требования:

1. Аналитические умения и знания веб-аналитики (Google Analytics, Яндекс.Метрика).

2. Умения стратегического планирования, а также навыки в развитии сообщества и привлечении подписчиков без какой-либо накрутки ботов.

3. Коммуникабельность.

4. Владение графическими редакторами для качественного создания картинок и обработки фотографий/видео.

5. Умение написания грамотных и привлекательных постов.

6. Знание возможностей и ограничений социальных сетей и понимание специфики продвижения в каждой из них.

7. Стрессоустойчивость.

8. Опыт ведения социальных сетей.

Из этого следует, что SMM-специалист - это человек способный быстро обучаться, готов ко всему новому, умеющий постоянно быть в тренде, а также способный легко находить общий язык с разными людьми, выходить из конфликтных ситуаций и не боящийся стрессовых ситуаций.

В век информационного общества работа библиотеки должна быть ориентирована, в первую очередь, на пользователей, поэтому важно обратить 
внимание на работу в социальных сетях. В отличии от работы коммерческих аккаунтов, библиотеки не продают, а предлагают воспользоваться еe продуктами (взять книгу, посетить мероприятие, изучить ресурсы баз данных и т.д.).

Задачи библиотечного SMM:

1. Информирование: анонсы мероприятиях, объявления, списки новых поступлений в фонд, отчеты о проведении мероприятий и т.д. Цель - привлечь новых пользователей или подписчиков, увеличить посещаемость (реальную и виртуальную).

2. Привлечение внимания: при решении данной задачи важно проявить творчество, креатив и смекалку (это может быть интересная необычная дата или редкая книга, которую хорошо прорекламировали). Главная цель - убедить пользователя посетить библиотеку.

3. Получение обратной связи - важно наладить общение с виртуальными пользователями. Здесь помогут опросы, викторины, а также предложения делиться комментариями. Это более простой способ узнать мнения подписчиков как о странице (аккаунте, группе, сообществе), так и о библиотеке и скорректировать свою работу [4].

В заключение хотелось бы сказать, что библиотекарь, который работает в социальных сетях, должен владеть принципами работы SMM-специалиста, a также держать баланс ведя аккаунт библиотеки, быть высококультурным, но при этом живым и интересным для широкой аудитории [3], что невозможно без горящих глаз и любви к своей работе.

\section{Список использованной литературы}

1. Бабосов, Е. М. Роль креативной личности в развитии сетевого общества / Е. М. Бабосов ; НАН Беларуси, Институт социологии. - Минск : Беларус. навука, 2019. - 300 с.: ил. 
2. Копылова, Н. Библиотечный SMM: Кколько Можно Медлить? [Электронный ресурс] / Наталья Копылова // ЛибИнформ : информ. портал. - Режим доступа: http://libinform.ru/read/articles/Bibliotechnyj-SMM-Skolko-Mozhno-Medlit/. _ - Дата доступа: 12.12.2020.

3. Едакин, А. Готовый контент-план для соцсетей библиотеки [Электронный ресурс] / Алексей Едакин // SMM PLANNER : блог о маркетинге в социальных сетях. - Режим доступа: https://smmplanner.com/blog/gotovyi-kontient-plan-dlia-sotssietiei-bibliotieki/. - Дата доступа: 14.12.2020.

4. Башлыков, А. СММ специалист - кто это, какие у него обязанности и сколько он зарабатывает? [Электронный ресурс] / Артем Башлыков // Артем Башлыков : все про интернет маркетинг. - Режим доступа: https://artbashlykov.ru/smm-spetsialistkto-eto/. - Дата доступа: 14.12.2020.

5. Стиврень, В. СММ-специалист - кто это такой, чем он занимается и как им стать с нуля [Электронный ресурс] / Вероника Стиврень // В своем доме. - Режим доступа: https://vsvoemdome.ru/finansy/udalennaya-rabota/smm-specialist-kto-ehto. - - Дата доступа: 14.12.2020.

6. Халилов, Д. Маркетинг в социальных сетях / Д. Халилов. - М. : Манн, Иванов и Фербер, 2013. - 376 с.

7. Щербаков, С. Партизанский маркетинг в социальных сетях. Инструкция по эксплуатации SMM-менеджера / Сергей Щербаков. - 2-е изд., расширенное и доп. - СПб. [и др.] : Питер, 2019. - 317 с.: ил. - (Деловой бестселлер).

8. Альбрехт, Н. SMM в библиотеке [Электронный ресурс] / Наталья Альбрехт // SMM агентство BLACKMEDIA. - Режим доступа: https://vk.com/@blackmediainc-smm-vbiblioteke. - Дата доступа: 14.12.2020. 
DOI: $10.33581 / 2020-20-77-82$

\title{
КОМПЛЕКТОВАНИЕ БИБЛИОТЕЧНОГО ФОНДА: ЛОГИСТИЧЕСКИЙ ПОДХОД FORMATION OF LIBRARY COLLECTIONS: A LOGISTIC APPROACH
}

\begin{abstract}
Милюнец Антонина Чеславовна - научный сотрудник Белорусской сельскохозяйственной библиотеки им. И.С. Лупиновича Нацииональной академии наук Беларуси (Беларусь), e-mail: miliynets@belal.by
\end{abstract}

Miliynets Antanina Ch. - Researcher, I.S. Lupinovich Belarus Agricultural Library of the National Academy of Sciences of Belarus (Belarus), e-mail: miliynets@belal.by

Аннотация: Представлен краткий обзор термина «библиотекарькомплектатор». Теоретически обоснован логистический подход комплектования библиотечного фонда. Обозначены пути разрешения логистических конфликтов в комплектовании библиотечного фонда.

Abstract: Provides a brief overview of the term «acquisitions librarian». The logistic approach to the acquisition of the library collection has been theoretically substantiated. The ways of resolving logistic conflicts in the acquisition of the library collections are outlined.

Ключевые слова: комплектование библиотечного фонда, библиотекарь-комплектатор, библиотечный фонд, логистическая компетенция библиотекаря-комплектатора, библиотека, логистика.

Keywords: acquisition of the library collection, acquisitions librarian, library collections, logistics competence of the acquisitions librarian, library, logistics. 
Усиленное внимание к проблеме комплектования библиотечного фонда вызвано появлением новых видов комплектования (через консорциумы), его способов (репродуцирование, госзакупка документов, организация доступа к открытым Интернет-ресурсам и др.), а также процессов комплектования (выявление поставщика, изучение конъюнктуры документного рынка и др.).

Можно полагать, что эффективность и результативность комплектования фонда библиотеки зависит исключительно от компетенций библиотекаря-комплектатора.

Несмотря на то, что в научных публикациях термины «библиотекарькомплектатор» и «комплектатор» являются часто употребительными $[1 ; 2 ;$ и др.], обратим внимание на то, что точного определения этих категорий в нормативных документах, регулирующих деятельность библиотечного дела в Республике Беларусь, не содержится. Однако мы полагаем, что, рассматривая категорию «библиотекарь-комплектатор», следует исходить из видов профессиональной деятельности библиотечного специалиста. Так, вид профессиональной деятельности рассматривается как «совокупность трудовых функций, требующих обязательной профессиональной подготовки, рассматриваемых в контексте определенной сферы их применения, характеризующейся специфическими объектами, условиями, инструментами, характером и результатами труда» $[3$, с. 7]. Наша позиция находит свое подтверждение в локальных документах Гродненского государственного аграрного университета, а именно в Стандарте университета СТУ-3.4-2017 «Информационно-библиотечное обеспечение», где под «комплектатором» понимается «работник библиотеки, занимающийся комплектованием библиотечного фонда, изучением фонда, в обязанности которого входит: заказ и прием документов, их учет и начальная техническая обработка» [4, с. 10]. В «Библиотечной энциклопедии» термин «комплектатор» дается в более широком понимании, 
- в обязанности данного специалиста наряду с уже обозначенными, входит также «изучение фонда, исключение или передача документов на другие уровни хранения» [5, с. 515]. Опираясь на обозначенные формулировки, под библиотекарем-комплектатором мы будем понимать работника библиотеки, профессиональная деятельность которого направлена на комплектование библиотечного фонда. Одновременно отметим, что данное положение носит аналитический характер и не исключает других точек зрения на определение этого термина.

В контексте современного законодательства о государственных закупках в Республике Беларусь библиотека выступает полноправным субъектом рыночных отношений. Следовательно, процесс комплектования библиотечного фонда происходит в условиях конкурентоспособной среды, где значимым условием эффективной деятельности является слаженное взаимодействие всех этапов названного процесса. Для того, чтобы в процессе комплектования библиотечного фонда весь комплекс производственных задач решался оперативно и при этом эффективно и бесперебойно, необходимо рассматривать сам процесс комплектования библиотечного фонда в ключе логистического подхода.

Б.К. Плоткин относит логистику к универсальному научнопрактическому направлению, универсальность которого заключается в применении базисных функций логистики на различных уровнях деятельности организации - закупки, сбыт, транспортировка, хранение, запасы [6, с. 165]. Более того, логистику включают в разряд тектологических дисциплин, в которой применяются положения системного подхода [7, с. 26]. Следовательно, «в рамках выявления методологического содержания сущности логистического подхода целесообразно использовать в качестве его материальной категории общий системный подход» [8, c. 34]. Сущность логистического подхода к комплектованию библиотечного фонда определяется нами через экстраполяцию положений системного подхода, 
a его суть заключается в том, чтобы технологию комплектования рассматривать не как отдельные подпроцессы (отбор, финансирование документоснабжения и др.), а как эффективное движение потоков (документного, информационного, финансового) [9], которые ориентированы на создание качественного библиотечного фонда, а также на потребителя, применительно к библиотеке - пользователя. Исходя из этого, эффективность оценивается как соответствие, степень удовлетворения потребностей пользователя, «покупателя».

Логистический подход в комплектовании библиотечного фонда позволит сократить издержки, которые связаны с механизмом покупки и включением документа в составную часть библиотечного фонда. Если не уделить данному процессу должного внимания, это может привести к потерям и убыткам, которые заключаются в некачественно сформированном фонде библиотеки, что, в конечном счете, затруднит своевременное и полноценное удовлетворение информационных потребностей пользователей библиотеки. Следовательно, можно считать, что логистический подход к комплектованию библиотечного фонда позволяет разрешить некоторые существующие конфликты в деятельности, направленной на комплектование библиотечного фонда (Таблица 1). Такие конфликты назовем логистическими, так как логистика рассматривает поток изменений и стремится к его регулированию на всем его протяжении от закупки до потребления произведенной продукции ее покупателями [10], относительно комплектования фонда библиотеки - от закупки документа до его хранения. 
Таблица 1. - Пути разрешения логистических конфликтов в комплектовании библиотечного фонда

\begin{tabular}{|c|c|c|}
\hline $\begin{array}{c}\text { Логистический } \\
\text { конфликт }\end{array}$ & Противоречие & Урегулирование \\
\hline $\begin{array}{l}\text { Представление } \\
\text { содержания } \\
\text { документа }\end{array}$ & $\begin{array}{l}\text { Сочетание традиционных и } \\
\text { электронных форм } \\
\text { представления содержания } \\
\text { документа }\end{array}$ & $\begin{array}{l}\text { Следует учитывать: } \\
\text { - наличие технических средств для } \\
\text { чтения документа; } \\
\text { - стоимость документа; } \\
\text { - квалификация библиотекаря- } \\
\text { комплектатора. } \\
\text { Конфликт разрешен, если сотрудники } \\
\text { повышают свою квалификацию и } \\
\text { библиотека обновляет МТБ. }\end{array}$ \\
\hline $\begin{array}{l}\text { Периодичность } \\
\text { закупки } \\
\text { документов }\end{array}$ & $\begin{array}{l}\text { Несвоевременность подачи } \\
\text { заявок на приобретение } \\
\text { документов и } \\
\text { осуществление } \\
\text { библиотекарем- } \\
\text { комплектатором плановой } \\
\text { закупки }\end{array}$ & $\begin{array}{l}\text { Следует учитывать: } \\
\text { - удельный вес удовлетворенного } \\
\text { спроса; } \\
\text { - стоимость документа; } \\
\text { - информацию об аналогах. } \\
\text { Конфликт разрешен, если разработана } \\
\text { локальная документация: правила } \\
\text { обновления библиотечного фонда, } \\
\text { порядок подачи заявок на литературу. }\end{array}$ \\
\hline $\begin{array}{l}\text { Доставка } \\
\text { документа к } \\
\text { месту хранения }\end{array}$ & $\begin{array}{l}\text { Несвоевременная передача } \\
\text { партии документов }\end{array}$ & $\begin{array}{l}\text { Следует учитывать: } \\
\text { - объем передаваемой партии; } \\
\text { - вместимость средств для } \\
\text { транспортировки документов. } \\
\text { Конфликт разрешен, если внедрена } \\
\text { автоматизация доставки документов к } \\
\text { месту их хранения. }\end{array}$ \\
\hline
\end{tabular}

Коммуникационный процесс библиотекаря-комплектатора с субъектами документного рынка (правильность выстраивания которого, и, следовательно, его эффективность как неотъемлемой составляющей профессиональной деятельности) выражается в реализации логистической концепции Just in time, комбинации традиционных и альтернативных источников комплектования фонда библиотеки, что выступает эффективным средством формирования логистической компетенции библиотекаря- 
комплектатора и приводит к интеграции с компетентностью в комплектовании библиотечного фонда.

\section{Библиографические ссылки}

1. Вихрева, Г. М. Этический кодекс библиотекаря: взгляд комплектатора : (заметки по поводу дискуссии между Ю. Н. Столяровым и Ю. П. Мелентьевой) / Г. М. Вихрева // Вестн. Ом. ун-та. - 2003. - № 4. - С. 165-168.

2. Эйдемиллер, И. В. Школа комплектатора «нормативно-правовое регулирование формирования библиотечных фондов» (Москва, 6 сент. 2013 г.) / И. В. Эйдемиллер // Инф. бюл. РБА. - 2013. - № 68. - С. 50-52.

3. Словарь-справочник современного российского профессионального образования / авт.-сост. : В. И. Блинов [и др.] ; Федер. ин-т развития образования. - 1-е изд. М. : ФИРО, 2010. - 19 c.

4. Система менеджмента качества. Стандарт университета «Информационнобиблиотечное обеспечение» [Электронный ресурс] / Гродн. гос. аграр. ун-т. Режим доступа: https://www.ggau.by/downloads/smk/.pdf. - Дата доступа: 20.07.2020.

5. Библиотечная энциклопедия / редкол.: Ю. А. Гриханов [и др.] ; Рос. гос. б-ка. М. : Пашков дом, 2007. - 1299 с.

6. Плоткин, Б. К. Фундаментальное понимание логистики в современной экономике / Б. К. Плоткин // Изв. С.-Петерб. ун-та экономики и финансов. - 2013. - № 5. C. $165-171$.

7. Афанасенко, И. Д. Логистика в системе совокупного знания / И. Д. Афанасенко, В. В. Борисова. - СПб. : Изд-во С.-Петерб. гос. экон. ун-та, 2013. - 395 с.

8. Таптунов, Л. А. Обоснование сущности категории «логистический подход» в контексте исследования агроэкономических систем / Л. А. Таптунов // Аграрная экономика. 2019. - № 2. - C. 33-39.

9. Милюнец, А. Ч. Логистические потоки как элемент управления комплектованием библиотечного фонда / А. Ч. Милюнец // Науч. и техн. б-ки. - 2020. - № 9. - С. 78-94.

10. Есенькин, Б. С. Логистика в книжном деле : учебник / Б. С. Есенькин, М. Д. Крылова ; Моск. гос. ун-т печати. - М. : МГУП, 2002. - 334 с. 
DOI: $10.33581 / 2020-20-83-86$

ФОРМИРОВАНИЕ МЕДИЙНО-ИНФОРМАЦИОННЫХ КОМПЕТЕНЦИЙ У СТУДЕНТОВ УЧРЕЖДЕНИЙ ВЫСШЕГО ОБРАЗОВАНИЯ РЕСПУБЛИКИ БЕЛАРУСЬ

\section{FORMATION OF MEDIA AND INFORMATION COMPETENCIES AMONG STUDENTS INSTITUTIONS OF HIGHER EDUCATION OF THE REPUBLIC OF BELARUS}

Соловьёва Екатерина Васильевна - заведующий научно-методическим отделом Фундаментальной библиотеки Белорусского государственного университета, e-mail: soloyva@bsu.by

Salauyova Katsiaryna - superintendent Scientific-methodical Department of the Fundamental library of the Belarusian State University, e-mail: soloyva@bsu.by

Аннотация: В докладе рассказывается о формировании медийной и информачионной грамотности студентов вузовских библиотеки; навыках, которые они получают при изучении программы «Информационная культура пользователей библиотек». Рассматриваются проблемь проведения таких занятий библиотекарями.

Abstract: The report describes the formation of media and information literacy of students of university libraries; the skills that they receive when studying the program "Information Culture of Library Users". The problems of conducting such classes by librarians are considered.

Ключевые слова: медийная грамотность, информационная грамотность, студенты, библиотечное дело, библиотеки, компетенции.

Keywords: media literacy, information literacy, students, librarianship, libraries, competencies. 
В современном мире общество основано на производстве и потреблении информации, а сама информация признается наиболее значимым ресурсом. Существует множество различных форм и видов информации, способов ее передачи, в том числе посредством интернет-сетей, a также различных коммуникационных и информационных технологий, влияние которых на нашу жизнь невозможно игнорировать. Поэтому одной из ключевых задач современного образования становиться обучение правильному ориентированию в информационных потоках, грамотному отбору и классификации информации, овладению информационнокоммуникационными технологиями. Все это может обеспечить обучение медийно-информационной грамотности, основной функцией которого является подготовка человека к активной и успешной жизни в информационном обществе.

Как показывает практика, на начальном этапе многие студенты не обладают умениями отбора и анализа качественной информации, применения полученных знаний в различных ситуациях, делать самостоятельные выводы и принимать обоснованные решения. Сегодня именно библиотеки УВО берут на себя функцию формирования медиаинформационной грамотности у студентов. Этому способствует проведения занятий со студентами младших курсов по программе «Информационная культура пользователей библиотек». Для старших курсов проводятся занятия по технологии поиска по базам данных, доступным в сети университета, занятия по правилам оформления научных работ. Библиотеки УВО Республики Беларусь в год проводят более 2000 часов таких занятий.

Расширение навыков и умений с помощью медийной и информационной грамотности является важной предпосылкой для обеспечения равноправного доступа к информации, знаниям и содействия свободным, независимым и плюралистическим средствам информации и информационным системам [1]. 
В ходе обучения по информационной грамотности студенты получают ряд следующих умений:

- умение находить качественные и правдивые источники информации;

- умение анализировать и оценивать информацию, полученную из многочисленных источников;

- умение накапливать необходимые знания для дальнейшей деятельности;

- умение создавать новую информацию;

- навык использования информационно-коммуникационных технологий при работе с информацией. [2]

Проведение занятий по медийной грамотности помогают студентам приобрести следующие навыки:

- способность видеть, слышать, создавать и интерпретировать медиа информацию;

- способность общаться при помощи медиа и примерять на себя различные медиароли;

- умение интерпретировать и понимать значение различных видов медиаресурсов;

- навык безопасного поведения в виртуальном пространстве и умение избегать вредоносных контактов и контента [3, с. 14].

Из этого можно сделать вывод, что библиотеки УВО Республики Беларусь активно работают по обучению медиа-информационной культуре своих пользователей. Стоит также отметить, что на современном этапе некоторые библиотеки УВО проводят свои занятия дистанционно, посредствам системы «Moodle». Но при этом преподаватели курса из года в год сталкиваются с однотипными проблемами:

1. недостаточно специально оборудованных помещений для проведения занятий с применением современных 
информационных технологий, техника устаревшая и работает медленно;

2. недостаточное количество выделяемых часов или полное их отсутствие;

3. курс не включен в учебные планы факультетов, что снижает его посещаемость студентами.

\section{Список использованной литературы}

1. Жилавская, О. П. Медийно-информационная грамотность как целостное понятие в изменяющемся мире [Электронный ресурс] / О. П. Жилавская // MIC: медиа, информация, коммуникация. - Режим доступа: http://mic.org.ru/vyp/teoriya-media-i$\underline{\text { mediaobrazovaniya/mediyno-informatsionnaya-gramotnost-kak-tselostnoe-ponyatie-v- }}$ izmenyayushchemsya/. - Дата доступа: 15.10.2020.

2. Гендина, Н. И. Информационная грамотность и информационная культура личности: международные тенденции и российский опыт // Школ. б-ка. - 2007. № $8 .-$ C. 74 .

3. Педагогические аспекты формирования медийной и информационной грамотности : [учебник / Суви Туоминен, Сиркку Котилайнен, Анниина Лундвалл, Марьо Лаакконен] ; ЮНЕСКО, Ин-т ЮНЕСКО по информ. технологиям в образовании. - М. : Ин-т ЮНЕСКО по информ. технологиям в образовании, 2012. - 140 с. : ил. 


\section{МЕЖДУНАРОДНОЙ НАУЧНО-ПРАКТИЧЕСКОЙ КОНФЕРЕНЦИИ «МЕНЕДЖМЕНТ ВУЗОВСКИХ БИБЛИОТЕК» - 20 ЛЕТ!}

Фундаментальная библиотека Белорусского государственного университета (ФБ БГУ), начиная с 2000 года ежегодно проводит Международную научно-практическую конференцию под общим названием «Менеджмент вузовских библиотек». Цель Конференции - обсуждение актуальных проблем библиотечно-информационной деятельности библиотек учреждений высшего образования (УВО), принятие и выполнение рекомендаций, способствующих расширению участия библиотек УВО в образовательном процессе и научных исследованиях в университетах; создание и использование корпоративных служб и информационных ресурсов; совершенствование библиотечно-информационного обслуживания (в том, числе с использованием автоматизированных средств); развитие библиотечного маркетинга. Статус Конференции, как научно-практической и международной, дает возможность эффективного сотрудничества библиотек УВО и обмена опытом, как на региональном, так и международном уровнях.

Каждая Конференция была посвящена определённой, актуальной теме. В совокупности в тематике Конференций отразились все современные тенденции и динамика развития библиотек УВО Беларуси с начала XXI века - основные события и изменения, происходящие в библиотечной профессиональной сфере, в сфере информатизации, в сфере высшего образования и общества в целом.

Одиннадцатая и четырнадцатая Конференции проходили под эгидой и при поддержке ЮНЕСКО. Соорганизаторами других Конференций в разные годы выступали: Министерство образования Республики Беларусь, Министерство культуры Республики Беларусь, Белорусская библиотечная ассоциация, Национальная библиотека Беларуси, Центральная научная 
библиотека НАН Беларуси, Институт им. Гёте в Минске, Инфорационный центр Посольства США, Отдел по сотрудничеству и культуре Посольства Франции в Беларуси, Польский институт в Минске, Российская ассоциация электронных библиотек, библиотеки УВО Республики Беларусь.

Мобильность мест проведения Конференций позволила привлечь большое количество ее участников, в том числе из регионов. Конференции проходили на базе библиотек УВО Минска, Витебска, Гродно, Гомеля, Новополоцка, Барановичей.

В работе Конференции принимали участие представители Германии, Казахстана, Латвии, Литвы, Польши, России, США, Украины, Узбекистана, Франции. Общение с зарубежными специалистами стало началом налаживания дальнейших партнерских отношений между библиотеками УВО Беларуси и зарубежных стран, а также участия в международных проектах и консорциумах по доступу к зарубежным электронным ресурсам.

Нельзя не сказать о людях, которые являлись инициаторами и основными организаторами конференции «Менеджмент вузовских библиотек»: директора Фундаментальной библиотеки БГУ Петр Михайлович Лапо (I-XIV), который приложил максимум усилий, чтобы Конференция стала поистине международной; Владимир Геннадьевич Кулаженко (c XV); заведующие Научно-методическим отделом ФБ БГУ (в разные периоды времени) - Ирина Яковлена Василькович, Ирина Борисовна Стрелкова, Татьяна Ивановна Митюхина, Ольга Александровна Больнова; директора библиотек УВО, на базе которых проводились Конференции - Геннадий Васильевич Данилов, Оксана Борисовна Володина, Алла Михайловна Мицкевич, Серегей Викентьевич Шандора, Ирина Владимировна Дубко-Пивницкая, Александр Александрович Анохин, Валентина Ильинична Дзирко, Лилия Вацлавовна Горбунова, Алексей Витальевич Скалабан, Николай Владимирович Гринько, Инна Викторовна Юрик. 
Нет сомнений, что конференция «Менеджмент вузовских библиотек» внесла весомый вклад в развитие библиотек УВО РБ и профессиональную подготовку библиотекарей Беларуси. Главной чертой ежегодных Конференций является то, что они отражают всю полноту деятельности современной библиотеки УВО, немедленно реагируют на любые новшества (в области автоматизации информационно-библиотечных процессов, управления библиотекой, формирования информационной культуры и медиаграмотности пользователей, гуманитарно-просветительской деятельности, авторского права и др.).

По результатам международных научно-практических конференций «Менеджмент вузовских библиотек» издано 8 сборников материалов:

1. Менеджмент университетской библиотеки: материалы междунар. семинара. Новополоцк, 21-23 мая 2002 г. / М-во образования Республики Беларусь, Белорусская библиотечная ассоциация, Фундаментальная библиотека БГУ, Библиотека Полоцкого государственного университета; сост. Н.А. Яцевич. - Минск: ГИАЦ М-ва образования РБ, 2002. - 142 с.

2. Менеджмент библиотек учреждений образования: материалы IV Междунар. конф., Витебск, 27-29 мая 2003 г. / М-во образования РБ [и др.]; [под общ. ред. А.М. Мицкевич]. - Витебск: ВГУ им. П.М. Машерова, 2003. - 154 с.

3. Менеджмент вузовских библиотек: роль библиотеки в обеспечении учебного процесса вуза в контексте новой парадигмы образования: материалы 6-й Междунар. науч.-практ. конф., посвященной 65-летию Научной библиотеки Учреждения образования «Гродненский государственный университет им. Янки Купалы», Гродно, 23-25 марта 2005 г. / М-во образования Республики Беларусь, УО «Гродненский гос. ун-т им. Янки Купалы», Белорусская библиотечная ассоциация; [редкол.: Г.В. Данилов (отв. ред.) и др.]. - Гродно: ГрГУ, 2005. - 208 с.

4. VII-я Международная научно-практическая конференция «Менеджмент вузовских библиотек». Тема конференции 2006 года «От информационного общества к обществу знаний: Библиотека вуза в XXI веке»: материалы XII междунар. науч.-практ. конф., Минск, 
10-12 октяб. 2006 года [Электронный ресурс] / ФБ БГУ, Белорусская библиотечная ассоциация; дизайн и верстка А.А. Савко. - Минск, 2006. - 1 электрон. опт. диск (CD-ROM): зв., цв. ; 12 см.

5. Менеджмент вузовских библиотек. Роль библиотеки университета в формировании информационной культуры специалиста XXI века: материалы XII междунар. науч.-практ. конф., 12-14 октября 2011 г., Минск / Белорусская библиотечная ассоциация, БГУ, Фундаментальная библиотека; [редкол.: П.М. Лапо (отв. ред.), О.А. Больнова, Е.Н. Садовская ; под науч. ред. А.В. Рубанова]. - Минск: Изд. центр БГУ, 2012. - 239 с. - Электронная версия. - Режим доступа: http://elib.bsu.by/handle/123456789/3937. - Дата доступа. - 11.12.2014.

6. Менеджмент вузовских библиотек. Библиотеки учреждений высшего образования в обществе знаний: инновации в менеджменте и технологиях: материалы XIV Междунар. науч.-практ. конф., Гомель, 12-13 ноября 2014 г. / ФБ БГУ, б-ка УО «ГГТУ им. П.О. Сухого», б-ка УО «БТЭУ»; редкол.: П.М. Лапо (отв. ред), О.А. Больнова, В.И. Дзирко, Е.Н. Садовская]. - Минск: БГУ, 2015. - Деп. в БГУ 30.04.2015, № 001530042015. - Электронная версия. - Режим доступа: https://elib.bsu.by/handle/123456789/121916 - Дата доступа. - 11.05.2015.

7. Менеджмент вузовских библиотек. Университетская библиотека в условиях цифровой трансформации: материалы XVIII Международной научно-практической конференции, 28-29 ноября 2018 г., Минск / Фундаментальная библиотека БГУ ; [редкол.: В. Г. Кулаженко (отв. ред.), Больнова О. А., Садовская Е. Н., Михнюк А. И.]. - Минск : БГУ, 2019. - 63 с.: ил. + прил. - Библиогр. в конце отд. ст. № 007411062019. - Деп. в БГУ 11.06.2019. - Электронная версия. - Режим доступа: https://elib.bsu.by/handle/123456789/221159. Дата доступа. - 10.10.2019.

8. Менеджмент вузовских библиотек. Открытая наука: практики и модели сотрудничества: материалы XIX Междунар. науч.-практ. конф., Минск, 30-31 окт. 2019 г. / Белорус. гос. ун-т, Фундам. б-ка БГУ; редкол.: В.Г. Кулаженко (отв. ред.), О.А. Больнова, Е.Н. Садовская. - Минск: БГУ, 2019. - 92 с.: ил. - Электронная версия. - Режим доступа: https://elib.bsu.by/handle/123456789/241016. - Дата доступа. - 10.10.2019. 


\section{ПЕРЕЧЕНЬ МЕЖДУНАРОДНЫХ НАУЧНО-ПРАКТИЧЕСКИХ КОНФЕРЕНЦИЙ «МЕНЕДЖМЕНТ ВУЗОВСКИХ БИБЛИОТЕК» (2000-2020)}

\begin{tabular}{|c|c|}
\hline I & $\begin{array}{c}\text { Тема } 2000 \text { года: «Вузовская библиотека на рубеже тысячелетий: } \\
\text { проблемы, поиски, решения» } \\
\text { г. Минск, Фундаментальная библиотека БГУ } \\
2000 \text { г. }\end{array}$ \\
\hline$\|$ & $\begin{array}{c}\text { Тема } 2001 \text { года: «Вузовские библиотеки: участие в информатизации } \\
\text { учебного процесса и научно-исследовательской работы» } \\
\text { г. Гродно, на базе Научной библиотеки } \\
\text { УО «Гродненский государственный университет им. Я. Купалы» } \\
\text { 22-23 мая } 2001 \text { г. }\end{array}$ \\
\hline III & $\begin{array}{c}\text { Тема } 2002 \text { года: «Менеджмент университетской библиотеки» } \\
\text { г. Новополоцк, на базе Научной библиотеки } \\
\text { УО «Полоцкий государственный университет» } \\
21-23 \text { мая } 2002 \text { г. }\end{array}$ \\
\hline IV & $\begin{array}{c}\text { Тема } 2003 \text { года: «Менеджмент библиотек учреждений образования» } \\
\text { г. Витебск, на базе Научной библиотеки } \\
\text { УО «Витебский государственный университет» } \\
\text { 27-29 мая } 2003 \text { г. }\end{array}$ \\
\hline $\mathbf{V}$ & $\begin{array}{c}\text { Тема } 2004 \text { года: «Менеджмент библиотек учреждений образования» } \\
\text { Стайки (Минский район), на базе РУП ОСК «Стайки» } \\
\text { 25-27 мая } 2004 \text { г. }\end{array}$ \\
\hline VI & $\begin{array}{c}2005 \text { год: «Менеджмент вузовских библиотек» } \\
\text { г. Гродно, посвящена 65-летию Научной библиотеки } \\
\text { УО «Гродненский государственный университет им. Я. Купалы» } \\
\text { 23-25 марта } 2005 \text { г. }\end{array}$ \\
\hline VII & 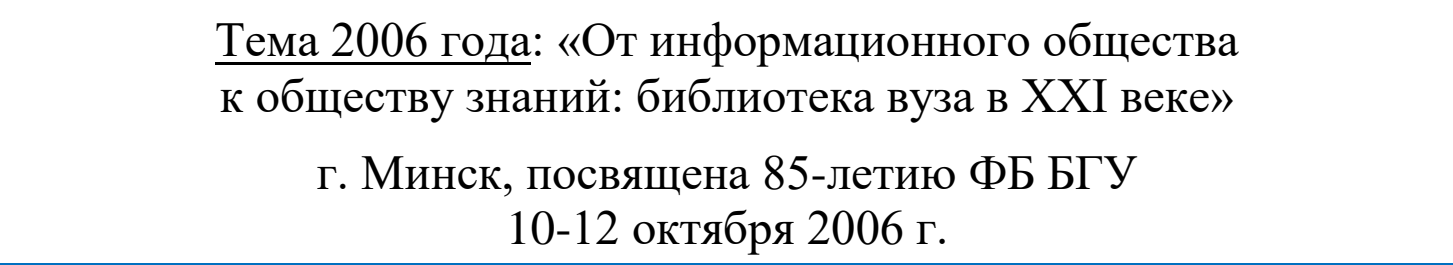 \\
\hline
\end{tabular}




\begin{tabular}{|c|c|}
\hline VIII & $\begin{array}{c}\text { Тема } 2007 \text { года: «Вузовская библиотека } \\
\text { в системе обеспечения качества образования) }\end{array}$ \\
\hline & $\begin{array}{c}\text { г. Минск, на базе библиотеки } \\
\text { Академии управления при Президенте РБ } \\
\text { 23-25 октября } 2007 \text { г. }\end{array}$ \\
\hline
\end{tabular}

\begin{tabular}{|c|c|}
\hline \multirow[t]{2}{*}{ IX } & $\begin{array}{c}\text { Тема } 2008 \text { года: «Библиотека вуза: в электронной среде: } \\
\text { технологии и инновации» (в формате on-line) }\end{array}$ \\
\hline & $\begin{array}{c}\text { г. Минск, на базе библиотеки } \\
\text { УО «Белорусский государственный экономический университет» } \\
30 \text { октября, } 2008 \text { г. }\end{array}$ \\
\hline \multirow[t]{2}{*}{$X$} & $\begin{array}{l}\text { Тема } 2009 \text { года «Система менеджмента качества как инструмент } \\
\text { управления и совершенствования деятельности библиотеки вуза» }\end{array}$ \\
\hline & $\begin{array}{c}\text { г. Новополоцк, г. Полоцк, на базе Научной библиотеки } \\
\text { УО «Полоцкий государственный университет» } \\
\text { 17-19 ноября } 2009 \text { г. }\end{array}$ \\
\hline \multirow[t]{2}{*}{ XI } & $\begin{array}{c}\text { Тема } 2010 \text { года "Электронные информационные ресурсы } \\
\text { и технологии для обеспечения качественного } \\
\text { образования и науки в вузе» }\end{array}$ \\
\hline & $\begin{array}{l}\text { г. Минск, посвящена 90-летию Научной библиотеки БНТУ } \\
222 \text { октября } 2010 \text { г. }\end{array}$ \\
\hline \multirow[t]{2}{*}{ XII } & $\begin{array}{c}\text { Тема } 2011 \text { года: «Роль библиотеки университета в формировании } \\
\text { информационной культуры специалиста XXI века» }\end{array}$ \\
\hline & $\begin{array}{l}\text { г. Минск, посвящена 90-летию Фундаментальной библиотеки БГУ } \\
\text { 12-14 октября } 2011 \text { г. }\end{array}$ \\
\hline \multirow[t]{2}{*}{ XIII } & $\begin{array}{c}\text { Тема } 2013 \text { года: «Роль библиотеки в информационном } \\
\text { обеспечении научно-исследовательской деятельности } \\
\text { университета» }\end{array}$ \\
\hline & $\begin{array}{c}\text { г. Барановичи, на базе библиотеки } \\
\text { УО «Барановичский государственный университет» } \\
13-15 \text { ноября } 2013 \text { г. }\end{array}$ \\
\hline \multirow[t]{2}{*}{ XIV } & $\begin{array}{l}\text { Тема } 2014 \text { года: «Библиотеки учреждений высшего образования } \\
\text { в обществе знаний: инновации в менеджменте и технологиях» }\end{array}$ \\
\hline & $\begin{array}{c}\text { г. Гомель, на базе библиотеки УО «Гомельский государственный } \\
\text { технический университет им. П.О.Сухого» } \\
12-13 \text { ноября } 2014 \text { г. }\end{array}$ \\
\hline
\end{tabular}




\begin{tabular}{|c|c|}
\hline $\mathbf{X V}$ & $\begin{array}{c}\text { Тема } 2015 \text { года: «Современная библиотека } \\
\text { в системе научных коммуникаций» } \\
\text { г. Минск, посвящена 95-летию Научной библиотеки БНТУ } \\
22-23 \text { сентября } 2015 \text { г. }\end{array}$ \\
\hline XVI & $\begin{array}{c}\text { Тема } 2016 \text { года: «Территория больших дел: } \\
\text { тренды в развитии современной библиотеки университета» } \\
\text { г. Минск, посвящена 95-летию Фундаментальной библиотеки БГУ } \\
\text { 4-6 октября } 2016 \text { г. }\end{array}$ \\
\hline XVII & $\begin{array}{c}\text { Тема } 2017 \text { года: «Библиотека в научно-образовательном } \\
\text { пространстве университета» } \\
\text { г. Гродно, на базе Научной библиотеки УО «Гродненский } \\
\text { государственный университет имени Янки Купалы» } \\
\text { 26-27 октября } 2017 \text { г. }\end{array}$ \\
\hline XVIII & $\begin{array}{c}\text { Тема } 2018 \text { года: «Университетская библиотека } \\
\text { в условиях цифровой трансформации» } \\
\text { г. Минск, в рамках II Международной специализированной } \\
\text { научно-технической выставки-форума } \\
\text { «Информационные технологии в образовании» ITE-2018 } \\
\text { 28-29 ноября } 2018 \text { г. }\end{array}$ \\
\hline $\mathbf{X I X}$ & $\begin{array}{c}\text { Тема } 2019 \text { года: «Открытая наука: } \\
\text { практики и модели сотрудничества» } \\
\text { г. Минск, Фундаментальная библиотека БГУ, } \\
\text { Научная библиотека БНТУ } \\
\text { 30-31 октября } 2019 \text { г. }\end{array}$ \\
\hline $\mathbf{X X}$ & $\begin{array}{c}\text { Тема } 2020 \text { года: «Библиотека в цифровой среде университета: } \\
\text { формируем будущее сегодня» (в формате on-line) } \\
\text { г. Минск, посвящена 100-летию Научной библиотеки БНТУ } \\
8-9 \text { декабря } 2020 \text { г. }\end{array}$ \\
\hline
\end{tabular}


«Вузовская библиотека на рубеже тысячелетий: проблемы, поиски, решения» Минск, 2000 г.

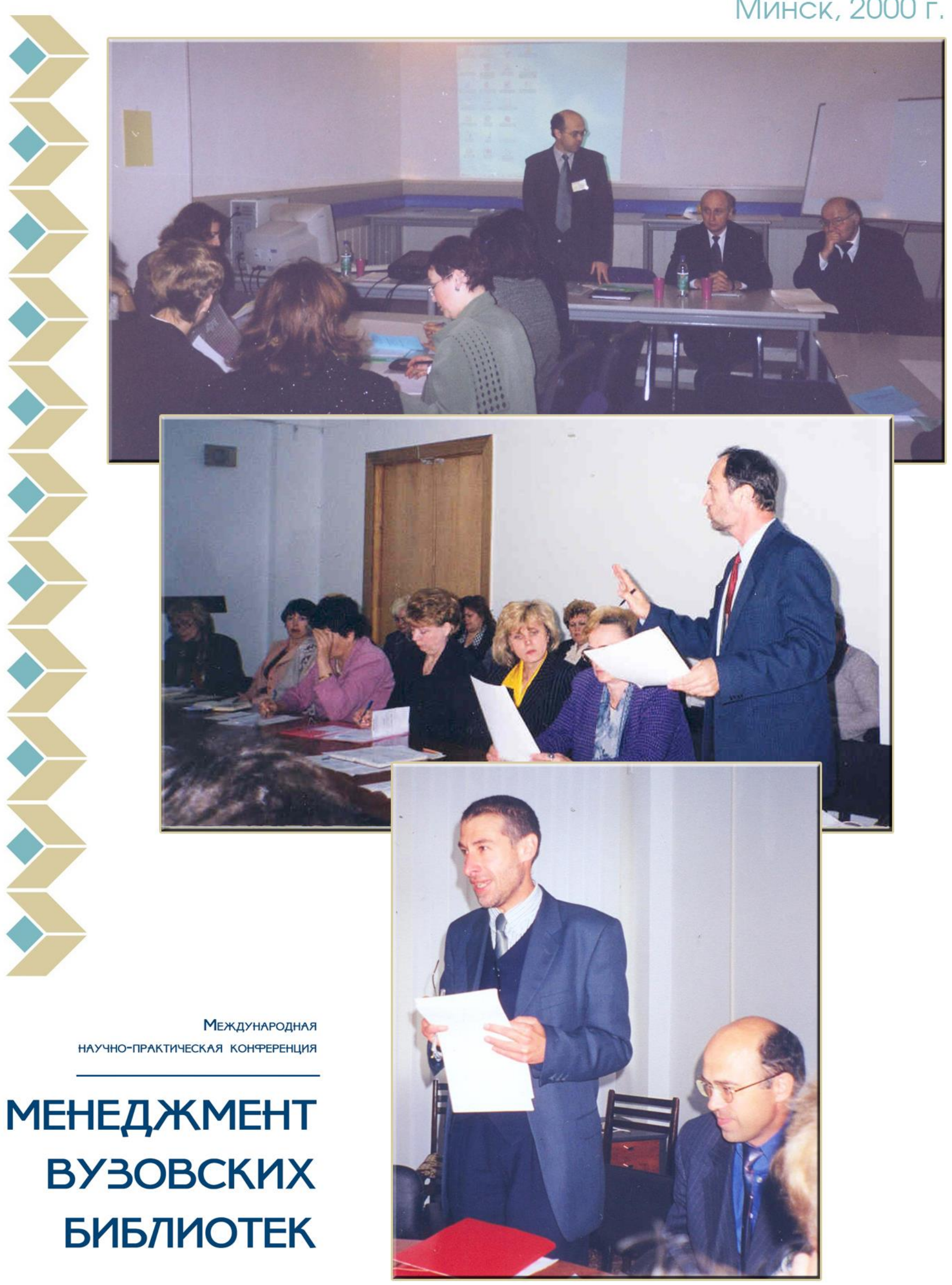


«Вузовские библиотеки: участие в индрорматизации учебного процесса и научно-исследователььской работы» ГрОМHO, 22-23.05.2001

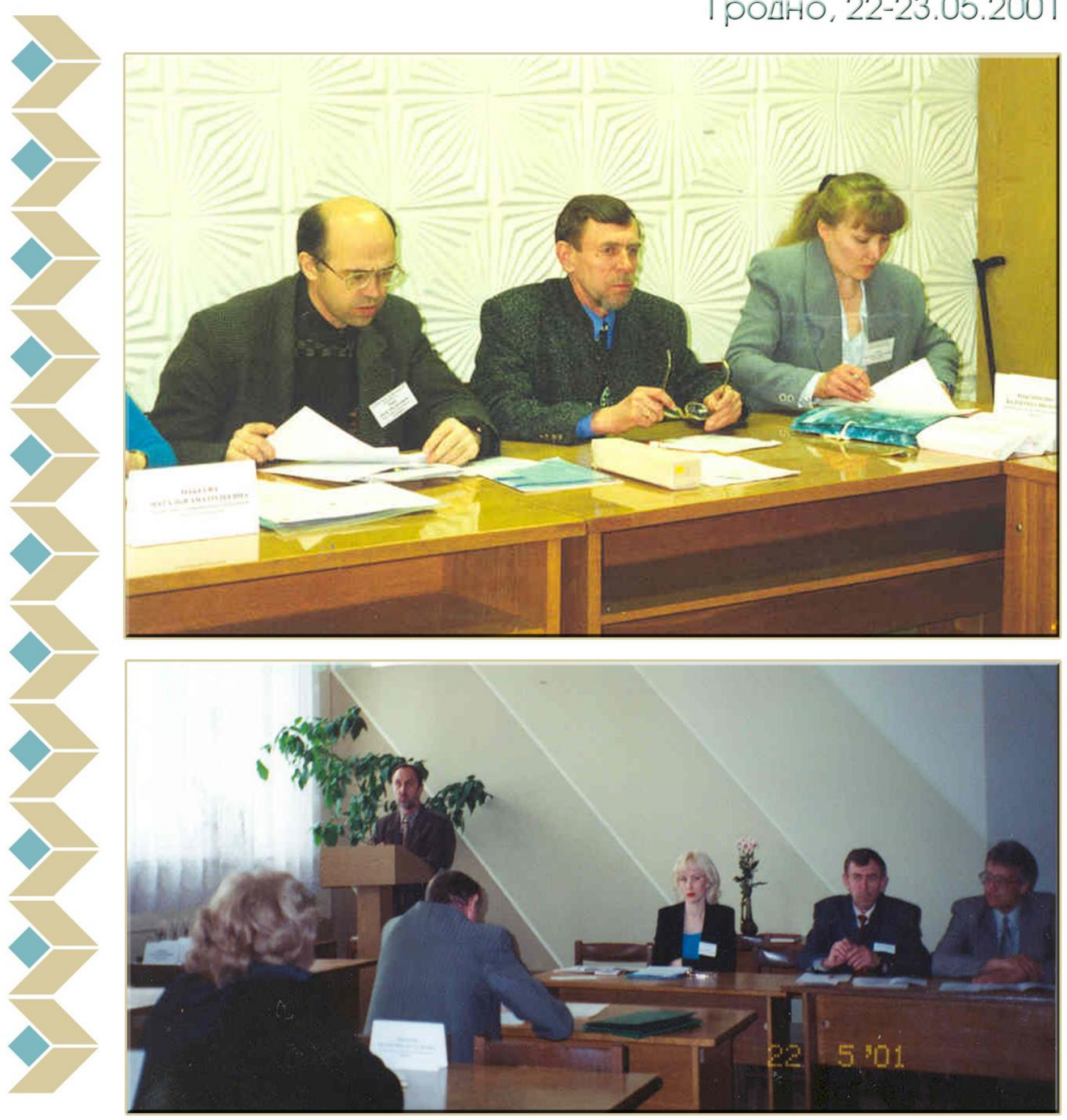

МЕЖДУНАРОДНАЯ

НАУЧНО-ПРАКТИЧЕСКАЯ КОНФЕРЕНЦИЯ

\section{МЕНЕДЖМЕНТ ВУЗОВСКИХ БИБЛИОТЕК}


«Менеджмент университетской библиотеки» Новополоцк, 21-23.05.2002
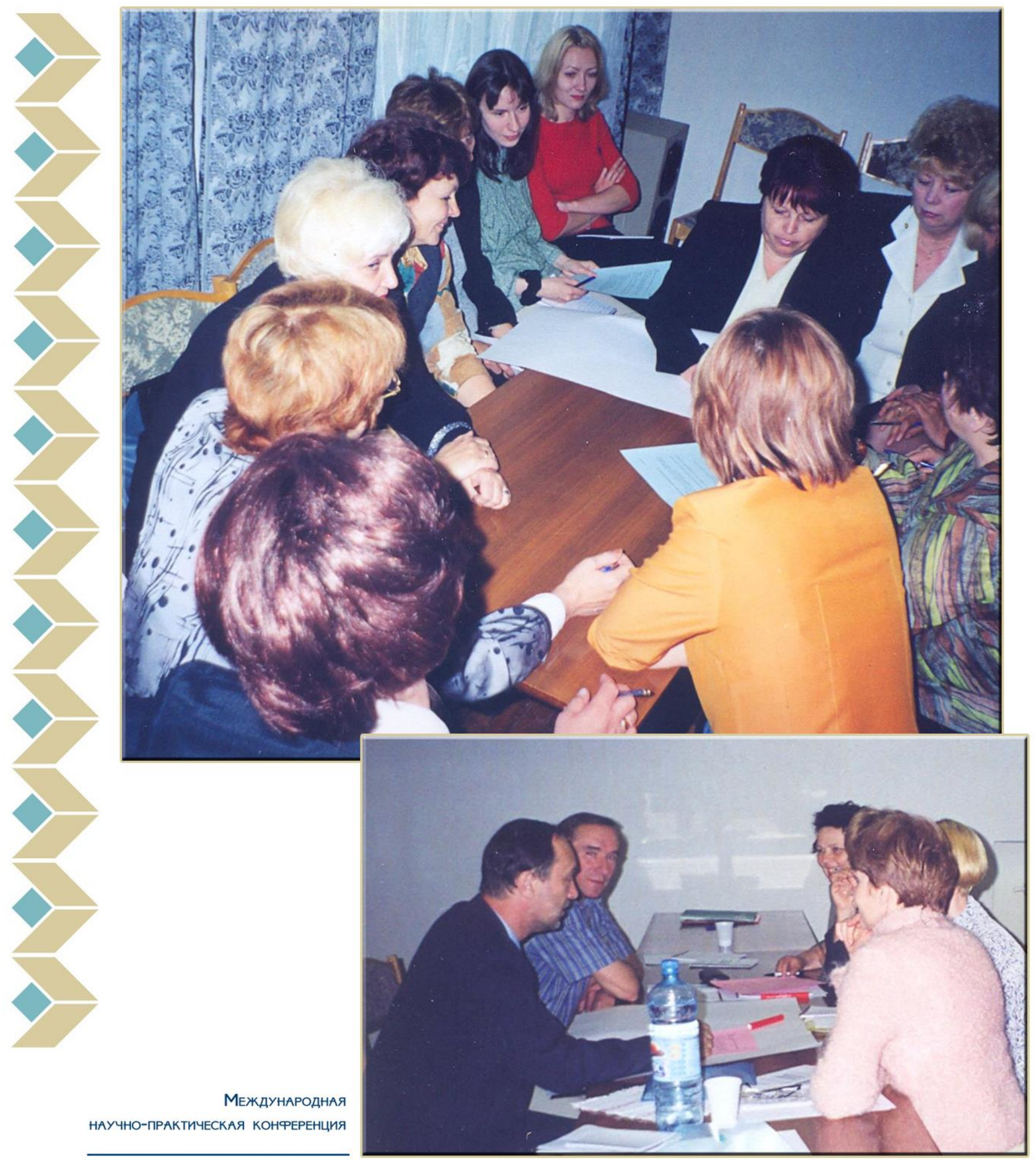

МЕНЕДЖМЕНТ ВУЗОВСКИХ БИБЛИОТЕК 
«Менеджмент библиотек учрежпений образования» Витебск, 27-29.05.2003

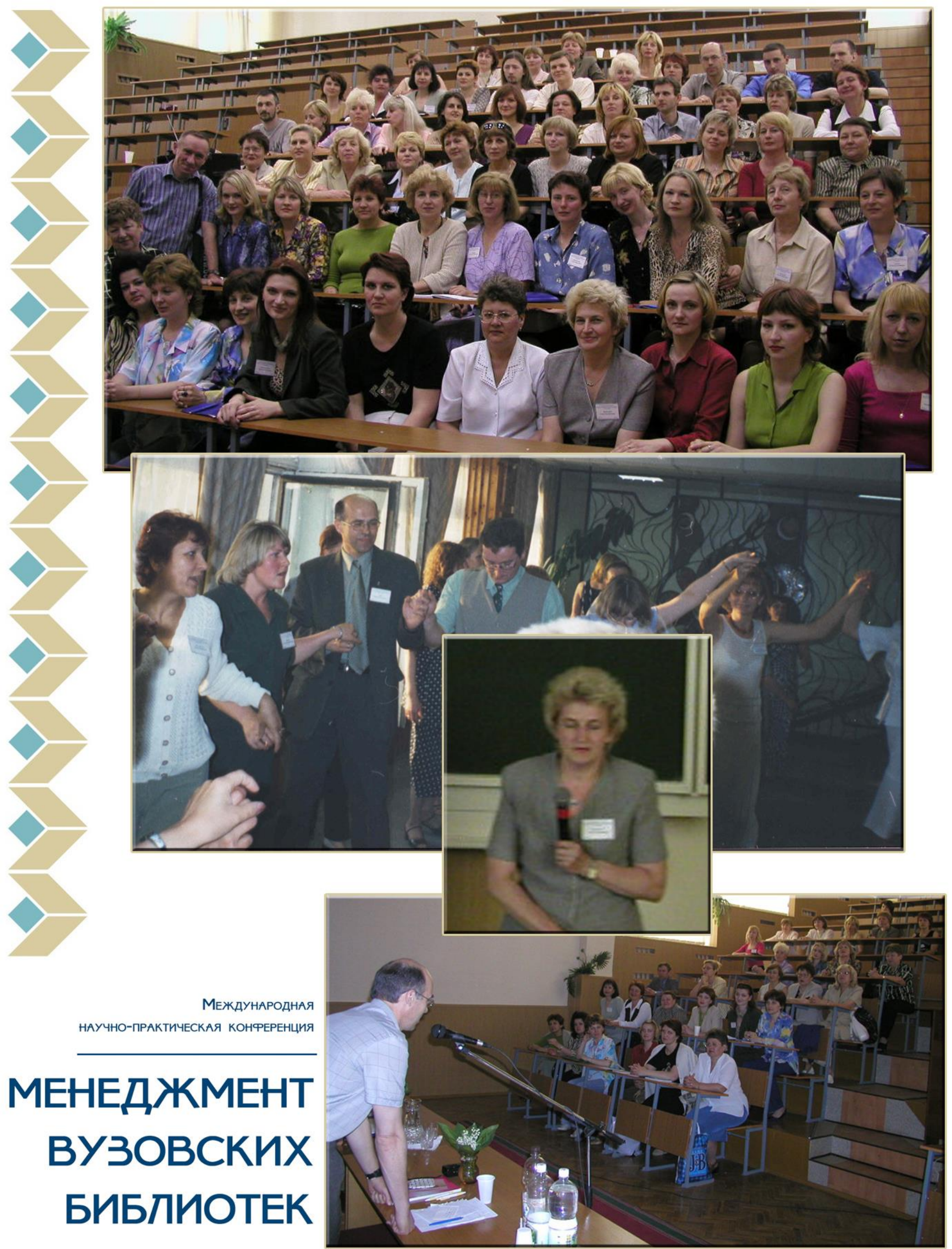


"Менеджмент библиотек учрежпений образованиял" Стайки, 25-27.05.2004

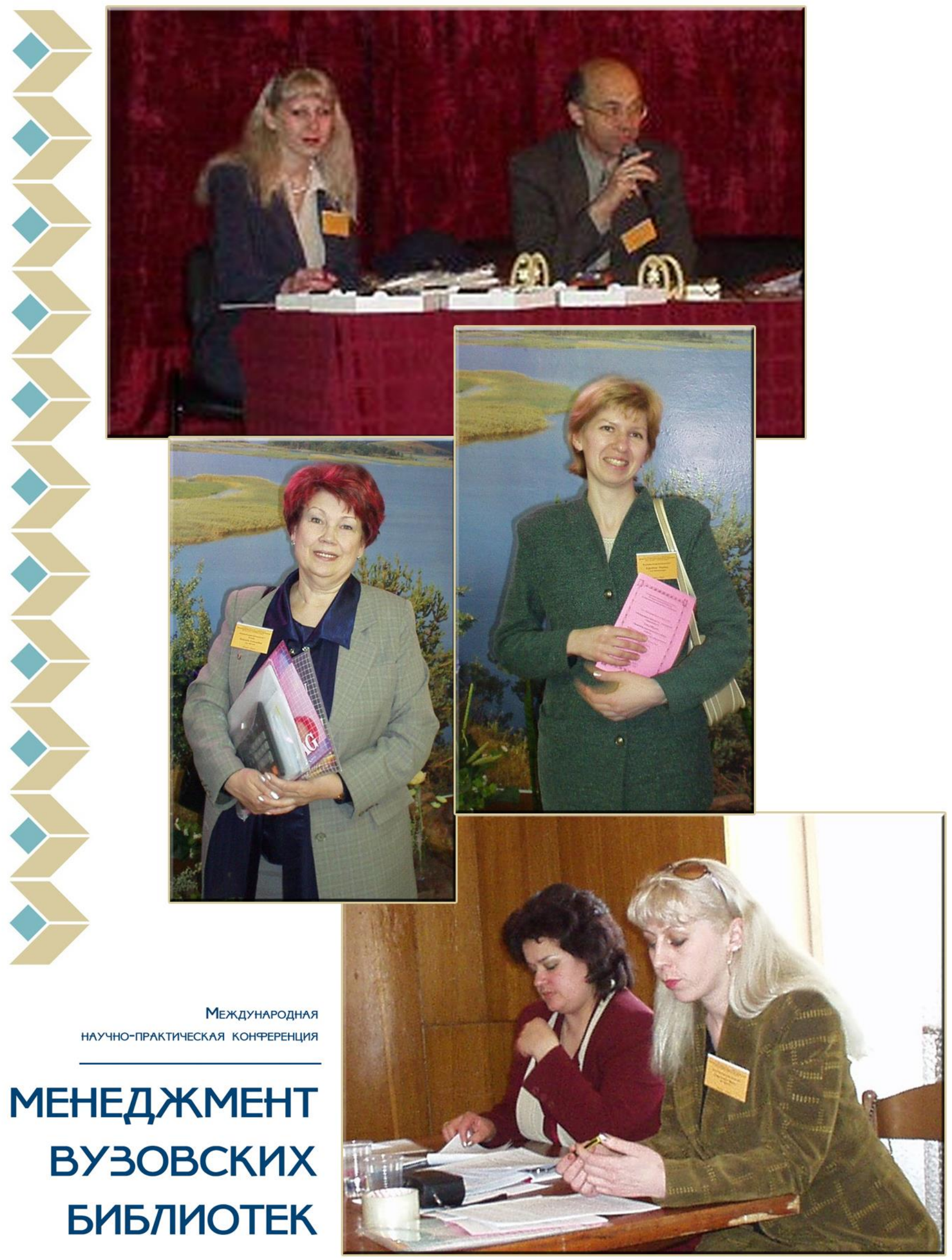


"Менеджмент вузовских библиотек" Гролно, 23-25.03.2005

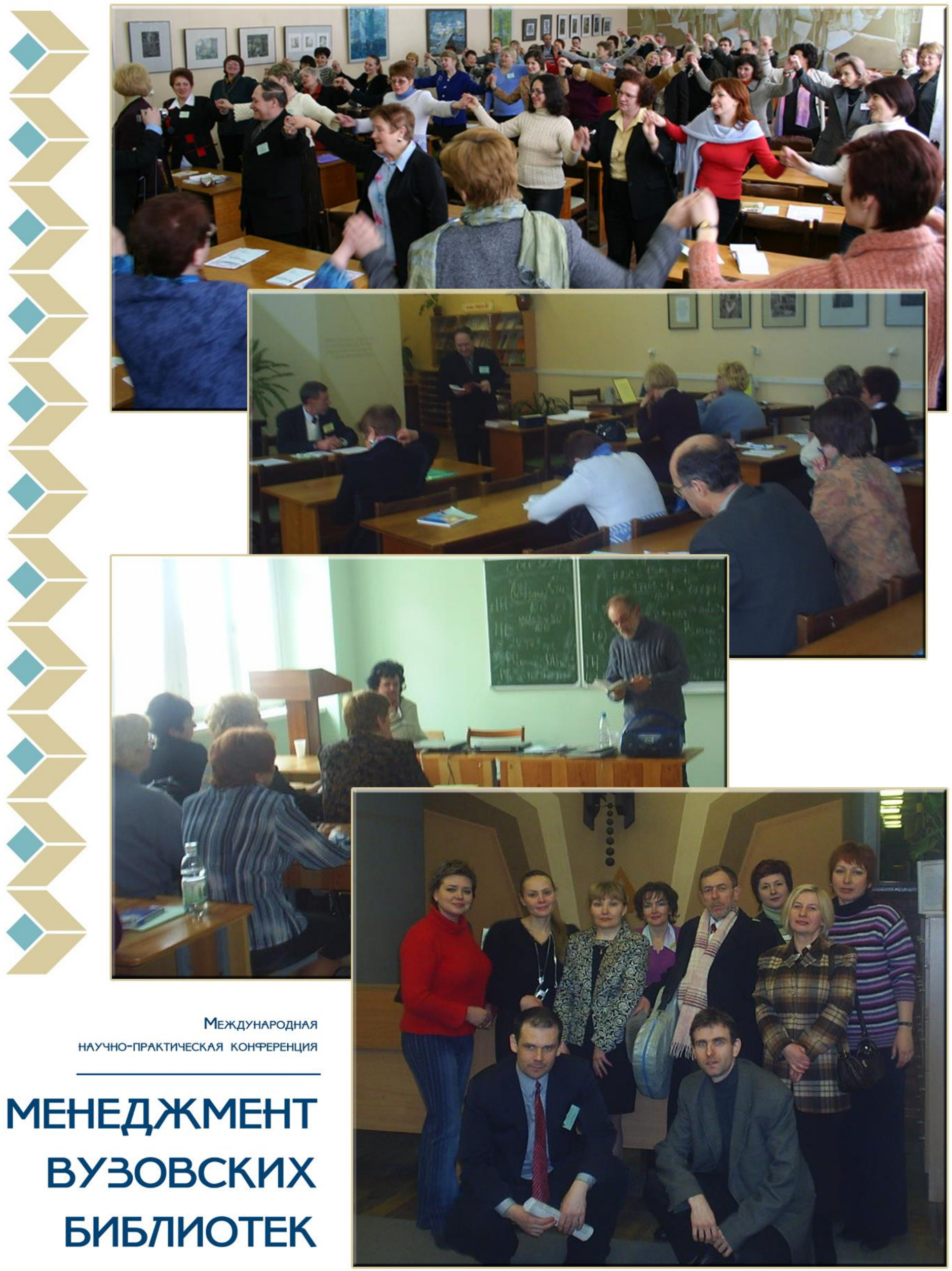


"От инсрормационного обшества к обшеству знаний: библиотека вуза в XXI веке», Минск, 10-12.10.2006

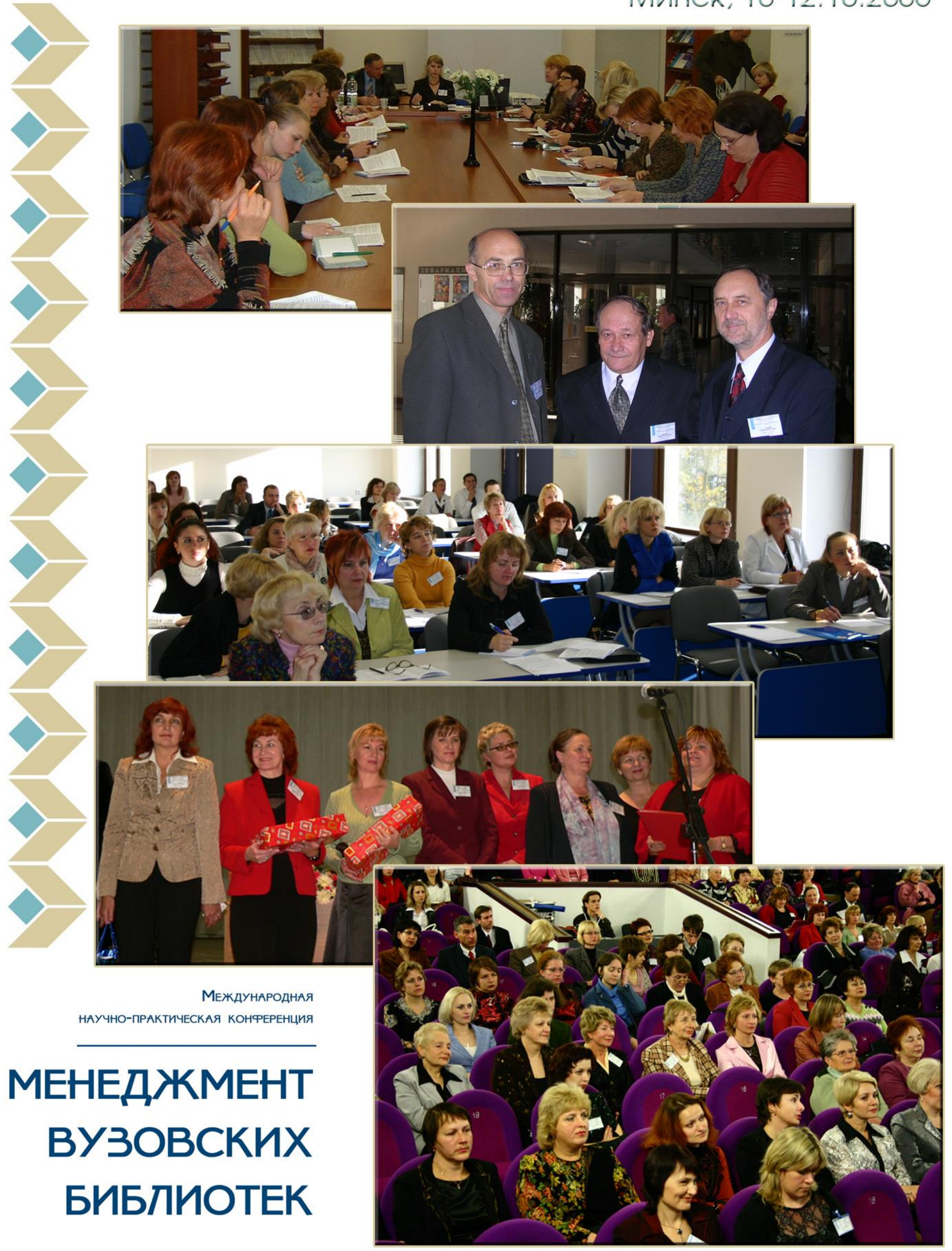


«Вузовская библиотека в системе обеспечения качества образованияя» Минск, 23-25. 10.2007

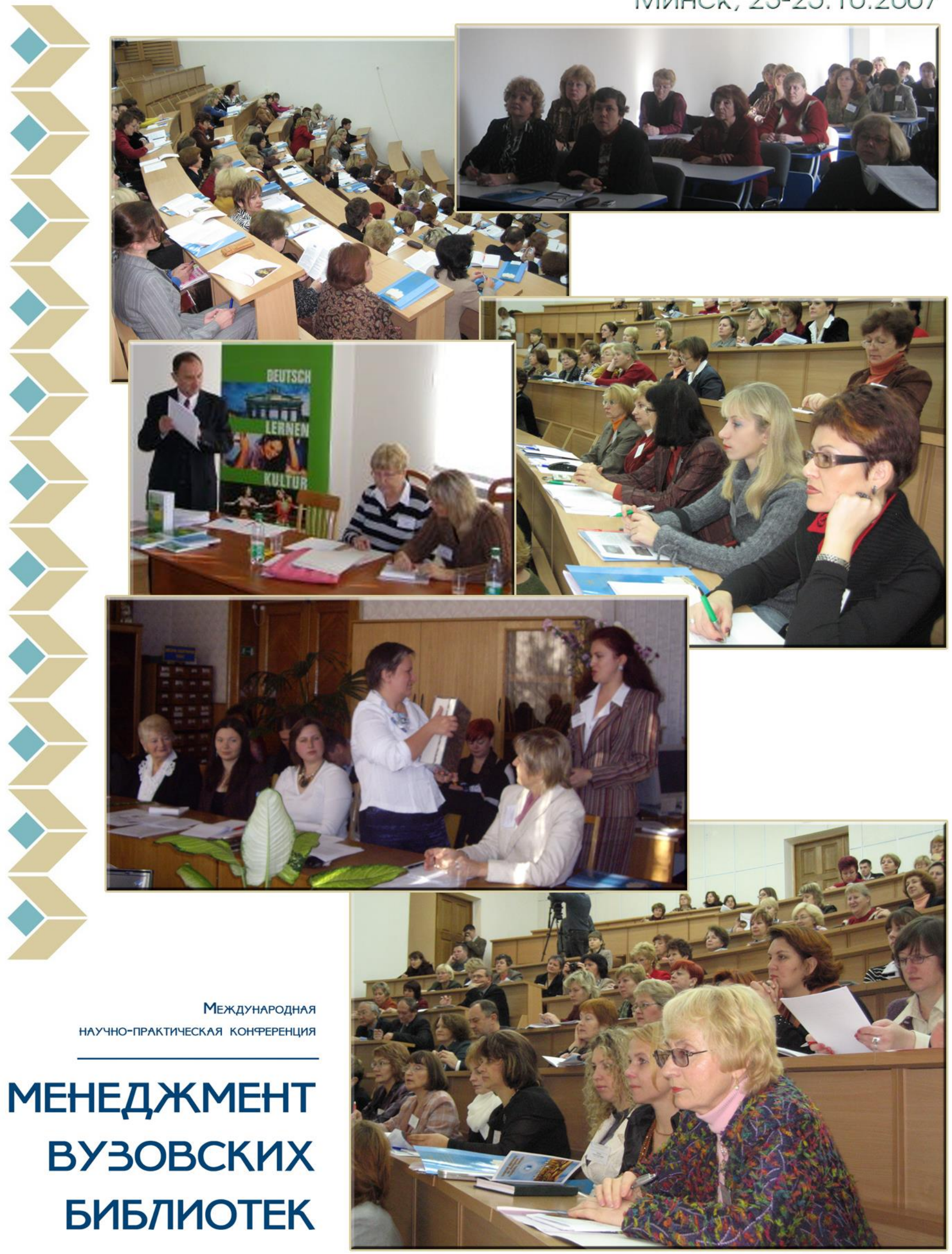


"Система менеджмента качества как инструмент управления и совершенствования деятельности библиотеки вуза» Новополоцк, Полоцк, 17-19.11.2009

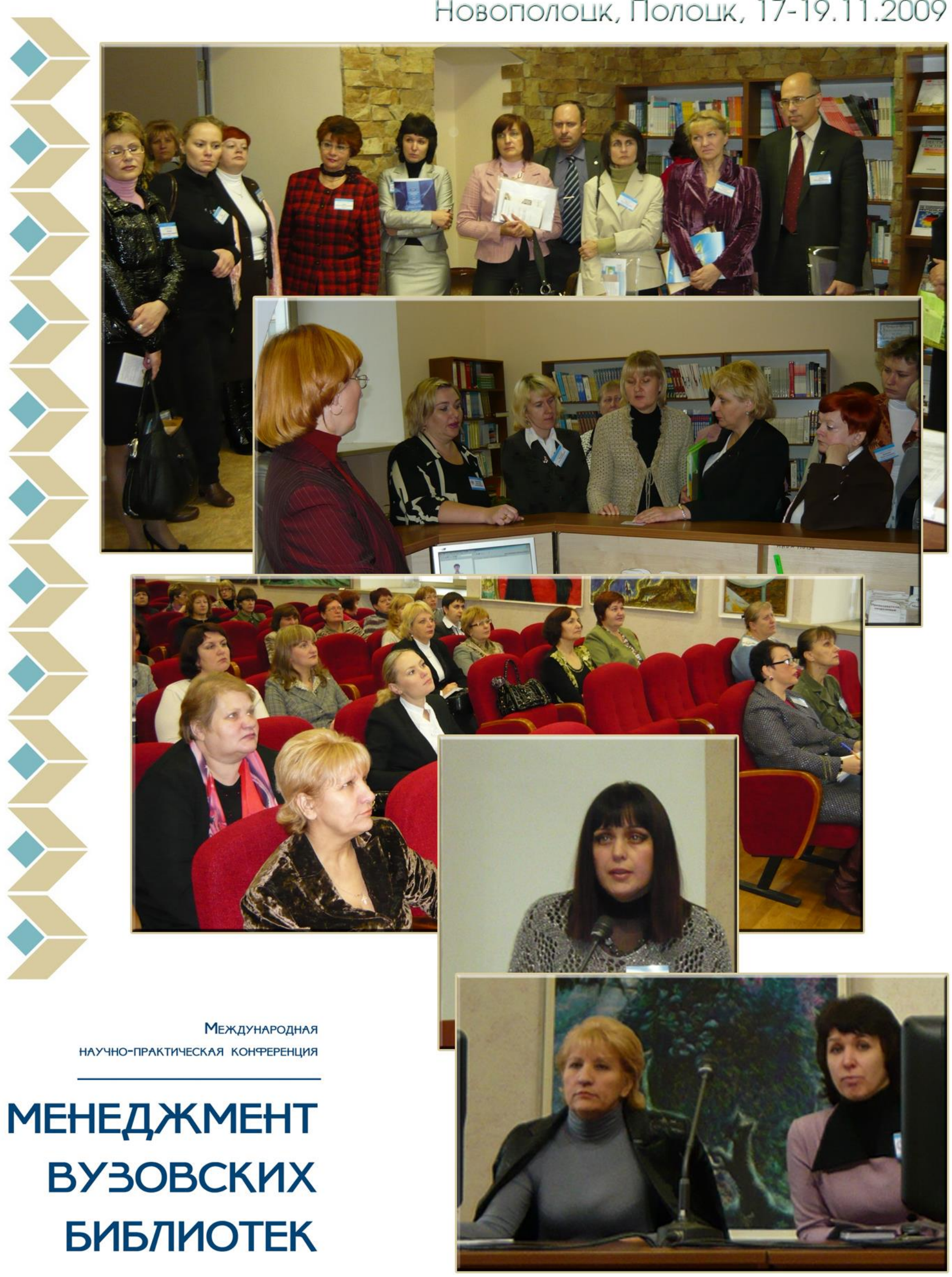


"Электронные инсрормационные ресурсы и технологии для обеспечения качественного образования и науки в вузе» Минск, 22. 10.2010

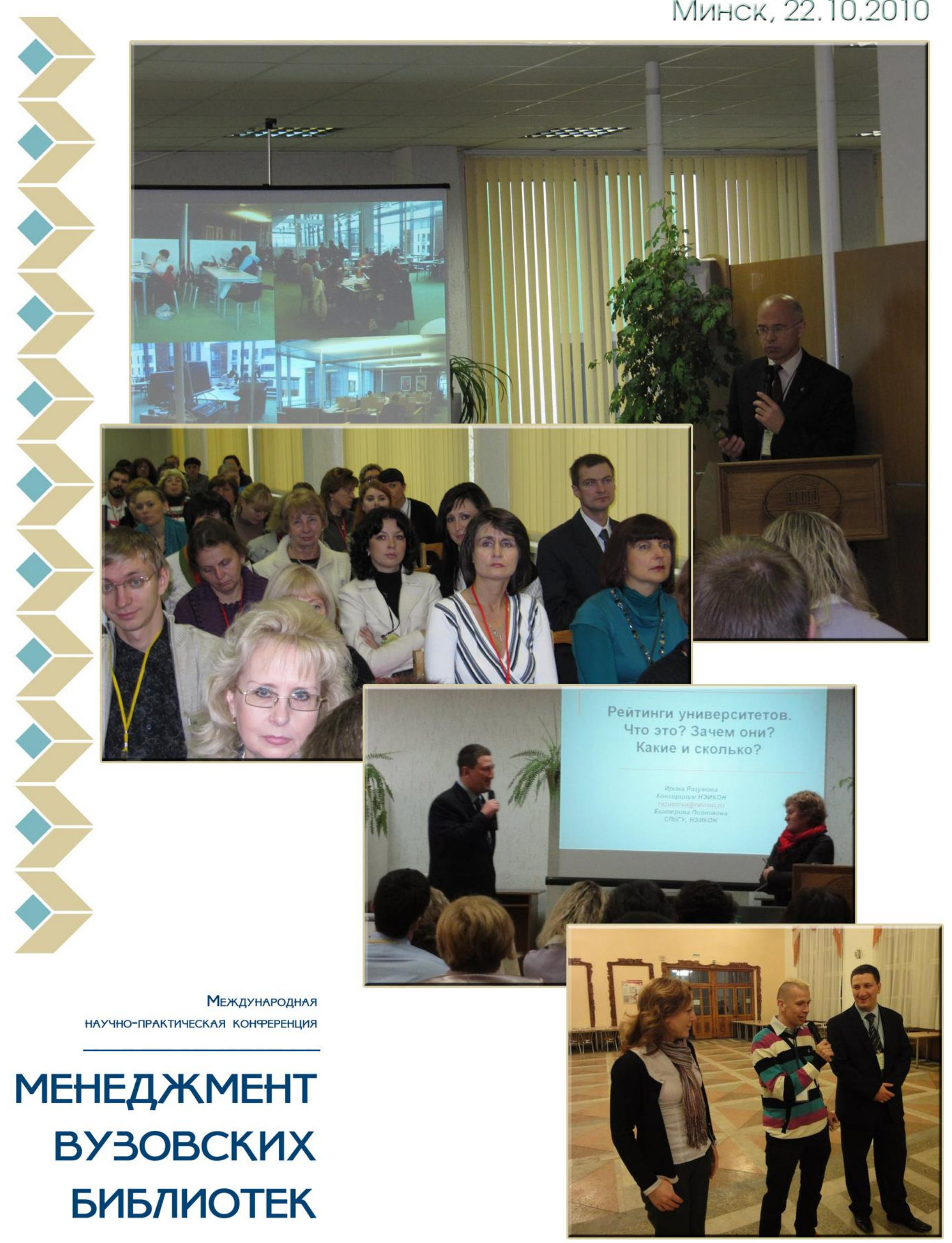


«роль библиотеки университета в соормировании Инфрормационной кУлььтуры специалиста XXI века» Минск, 12-14.10.2011

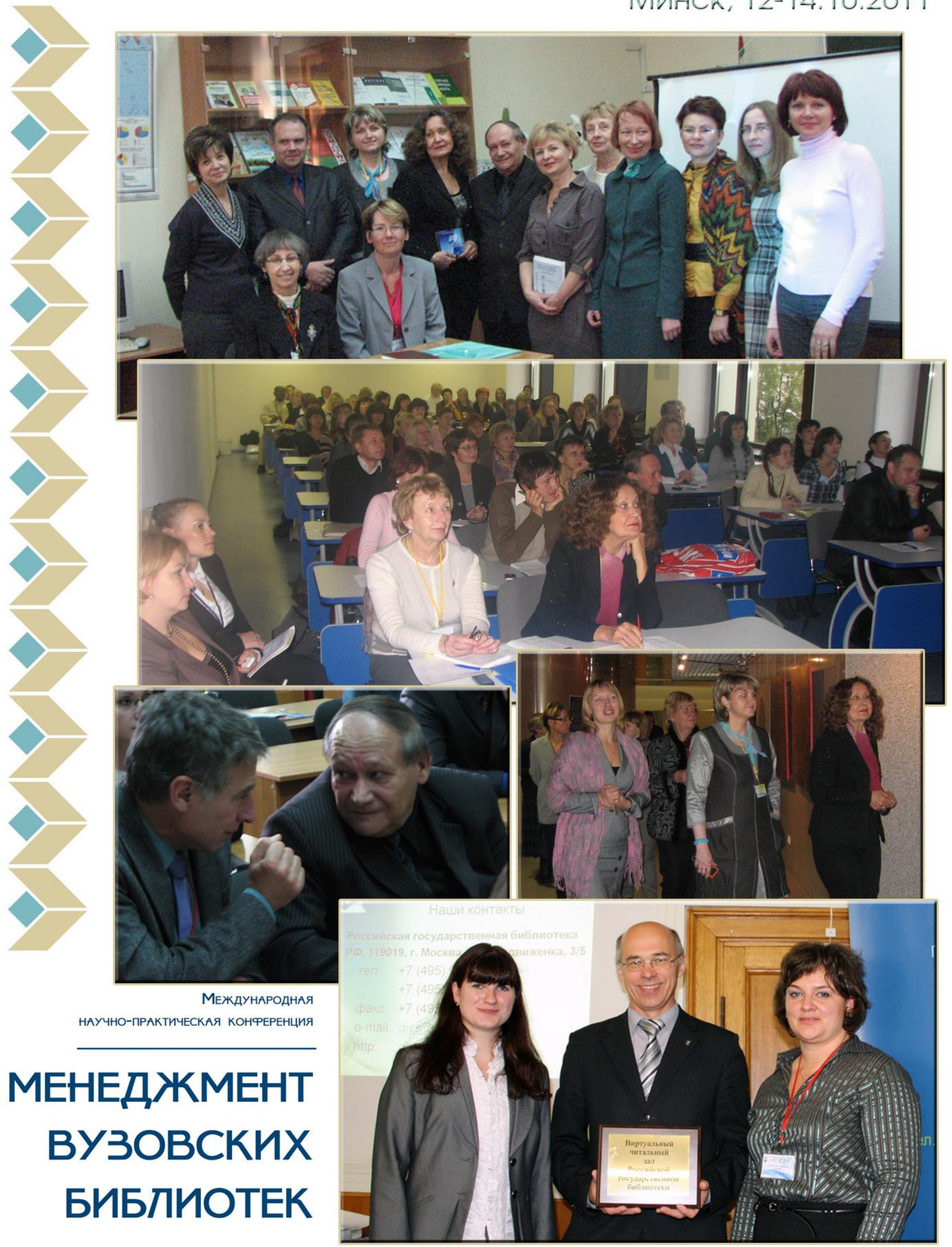


«Роль библиотеки в инсрормационном обеспечении научно-исследователььской деятельнности университета» Барановичи, 13-15.11.2013

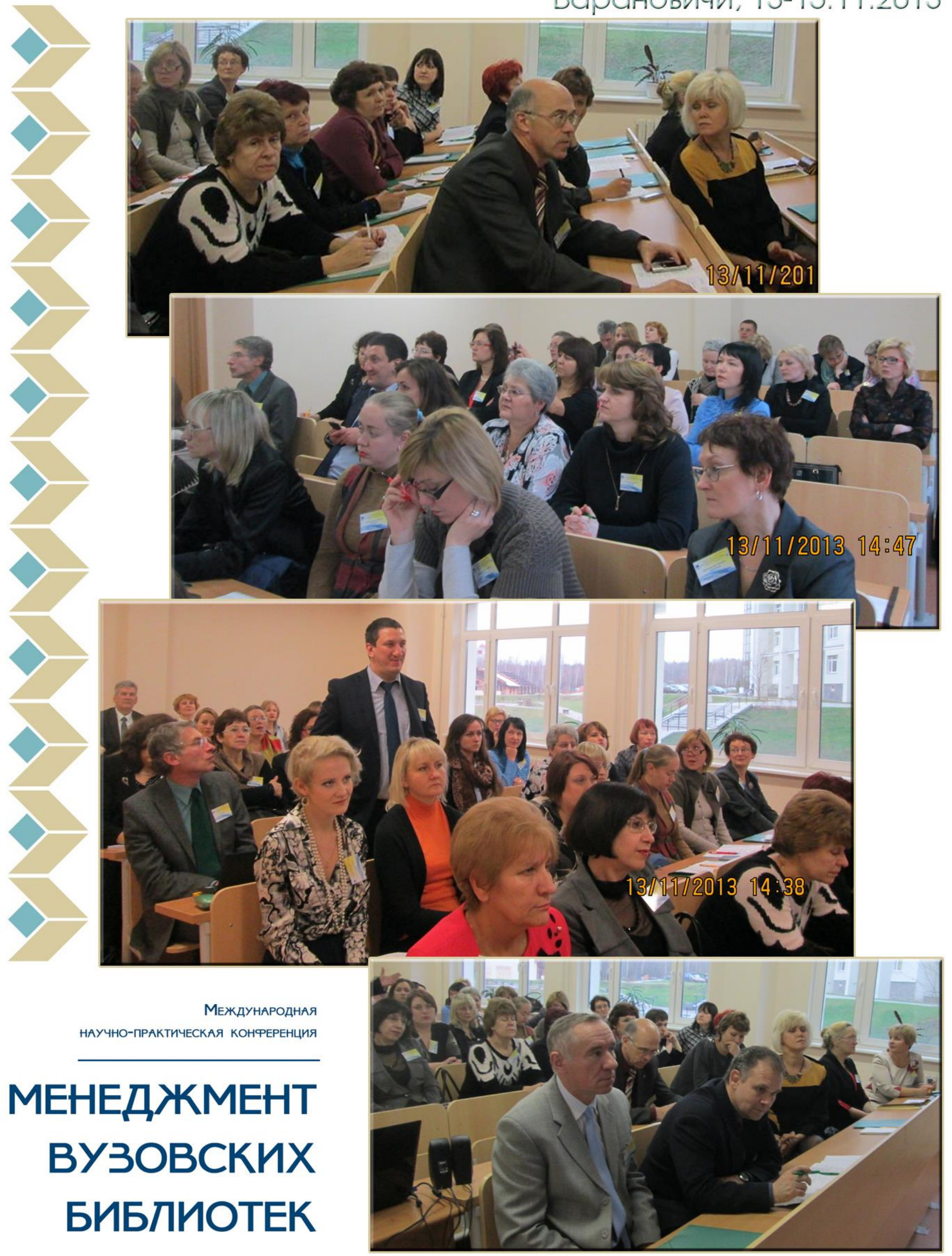


«Библиотеки учреждений высшего образования в обшестве знаний: инновации в менеджменте и технологиях" Гомелlb, 12-13.11.2014 
"Современная библиотека в системе научных коммуникаций» Минск, 22-23.09.2015

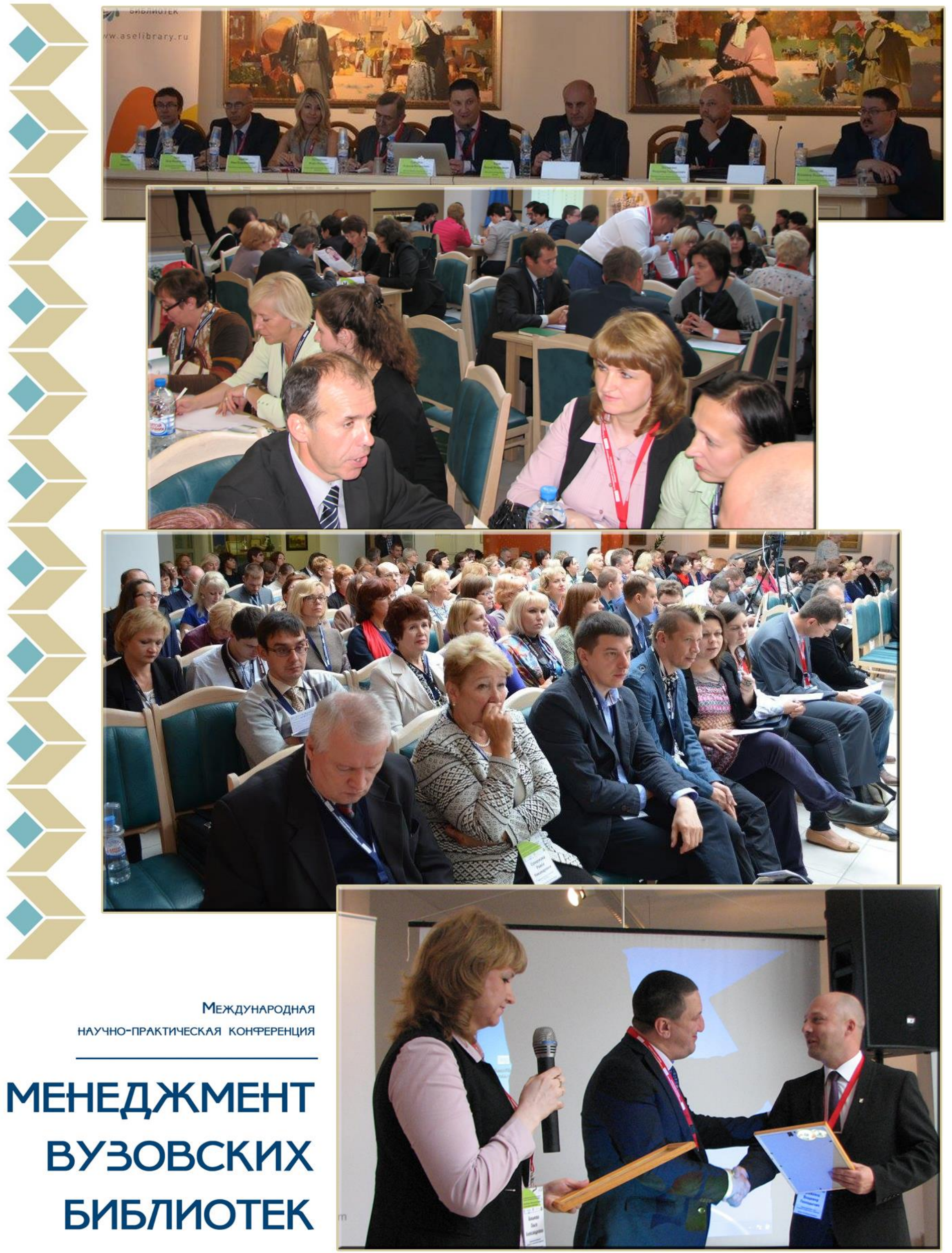


«Территория больших пел: тренцы в развитии современной библиотеки университета» Минск, 4-ó. 10.2016

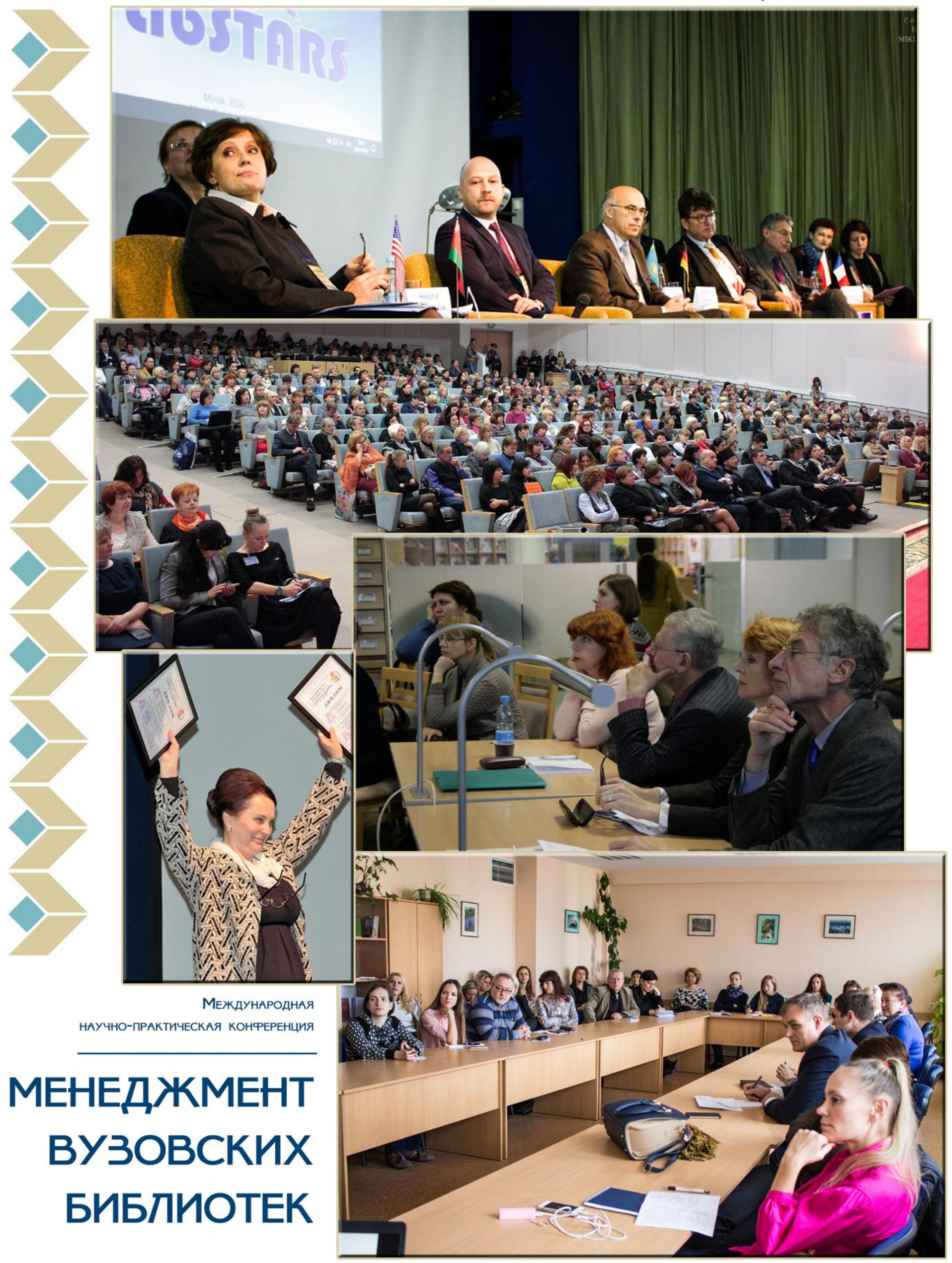


«Библиотека в научно-образовательном пространстве университета» Гродно, 26́-27.10.2017

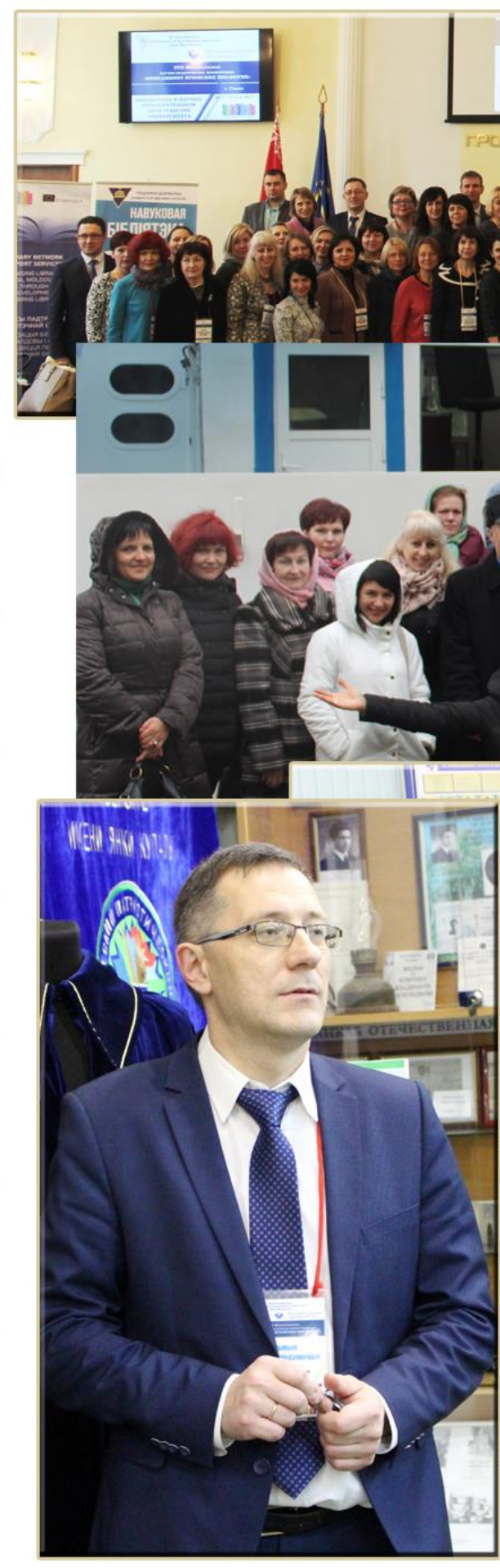

МЕЖДУНАРОДНАЯ НАУЧНО-ПРАКТИЧЕСКАЯ КОНФЕРЕНЦИЯ

МЕНЕДЖМЕНТ ВУЗОВСКИХ БИБЛИОТЕК
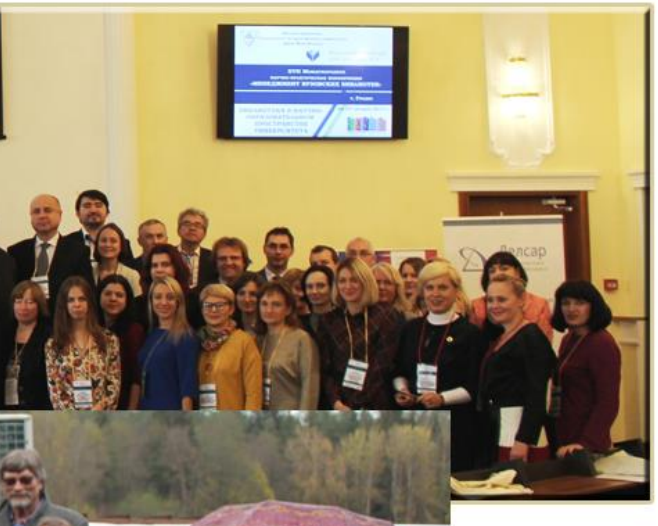
W-5i

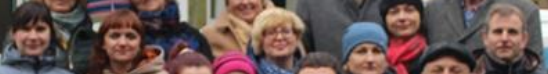

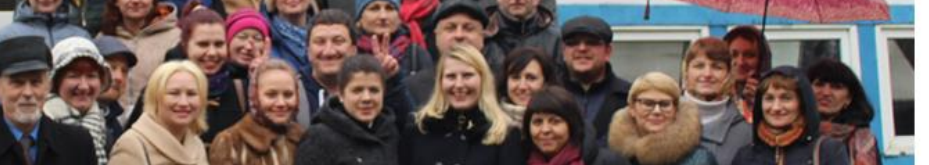
중
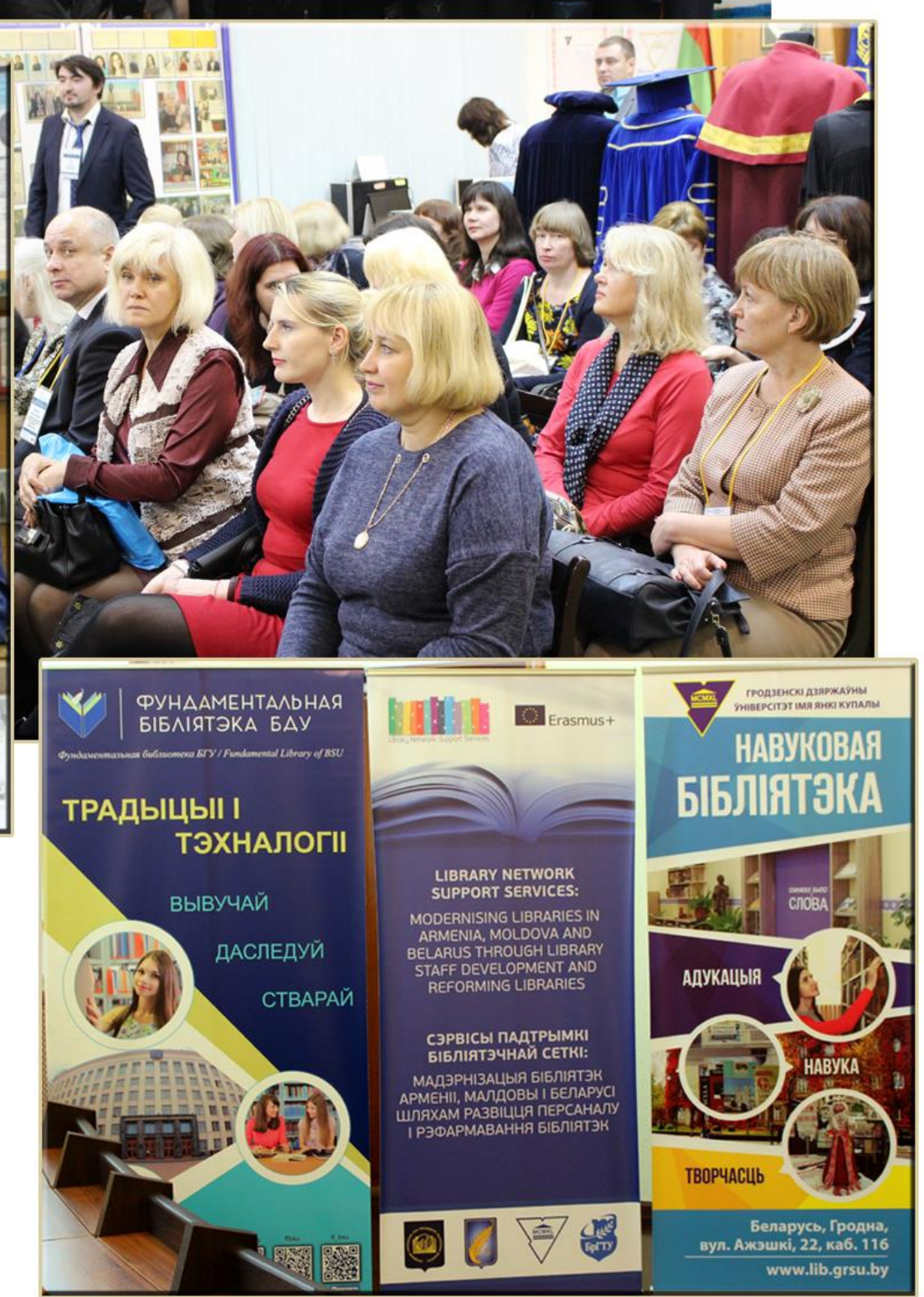
"Университетская библиотека в условиях Шиярровой трансфрормации» MиHсK, 28-29.11.2018

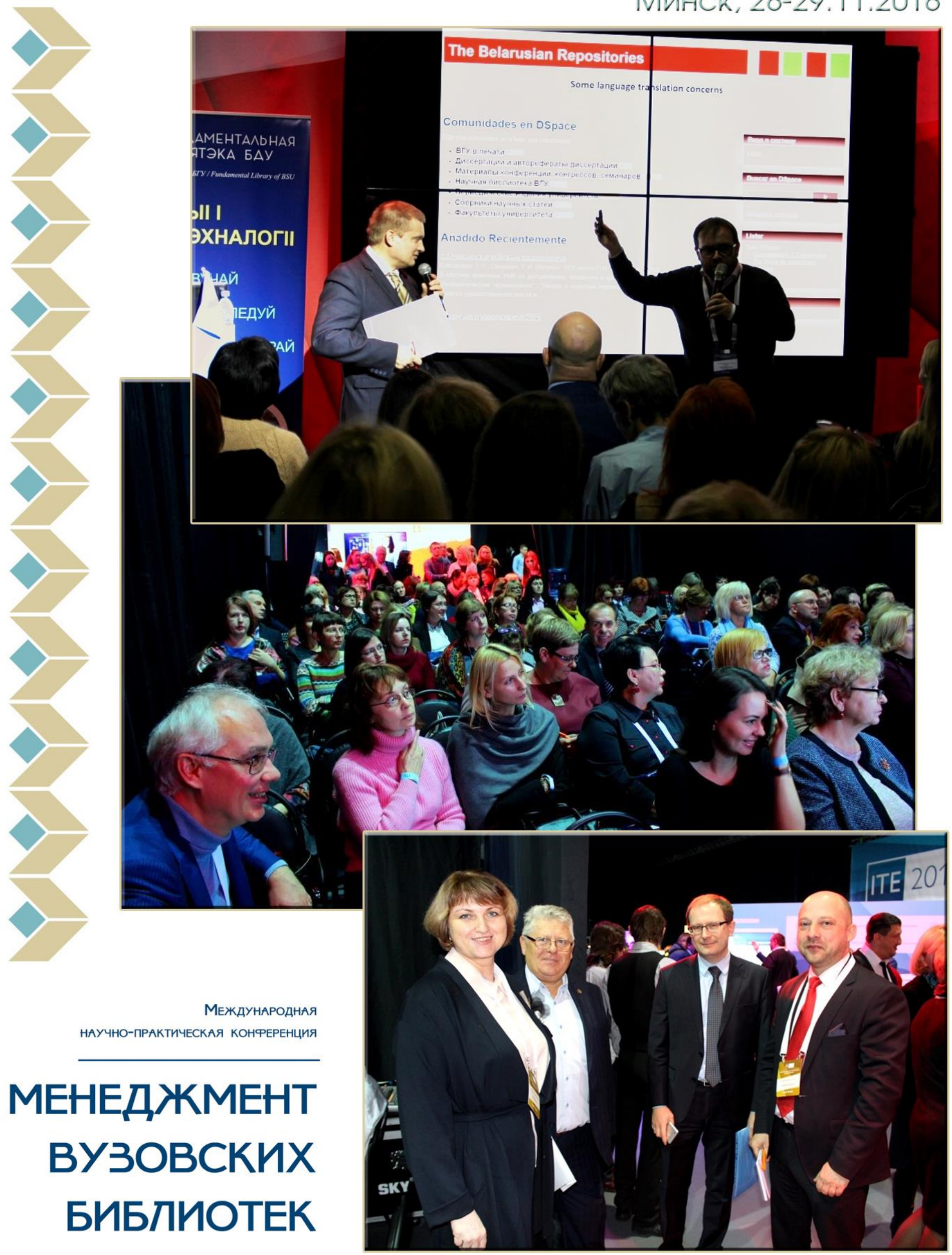


"Открытая наука: практики и модели сотрудничества» Минск, 30-31. 10.2019

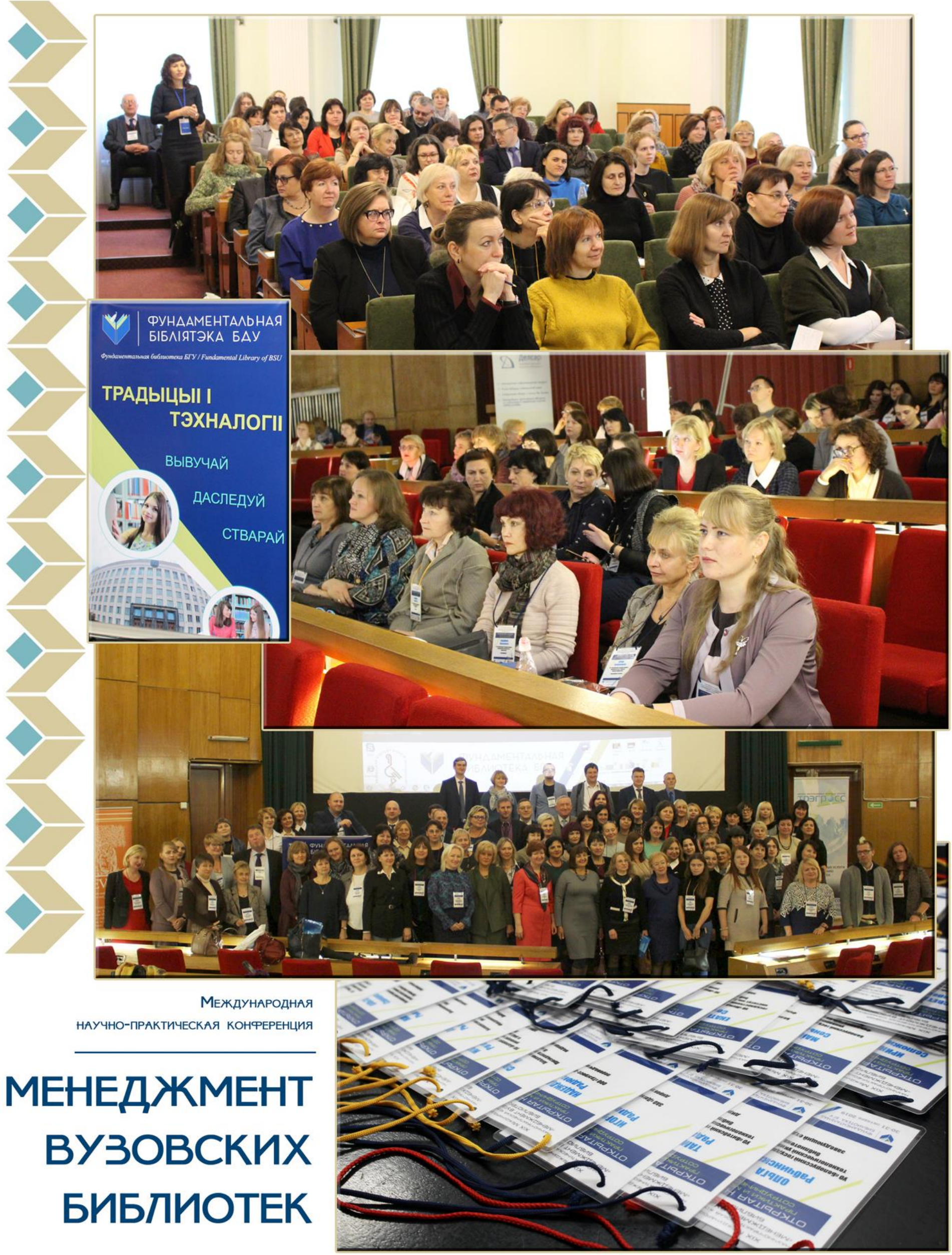


"Библиотека в циярровой среде университета: срормируем будушее сегодням (on-line)

Минск, 8-9. 12.2020
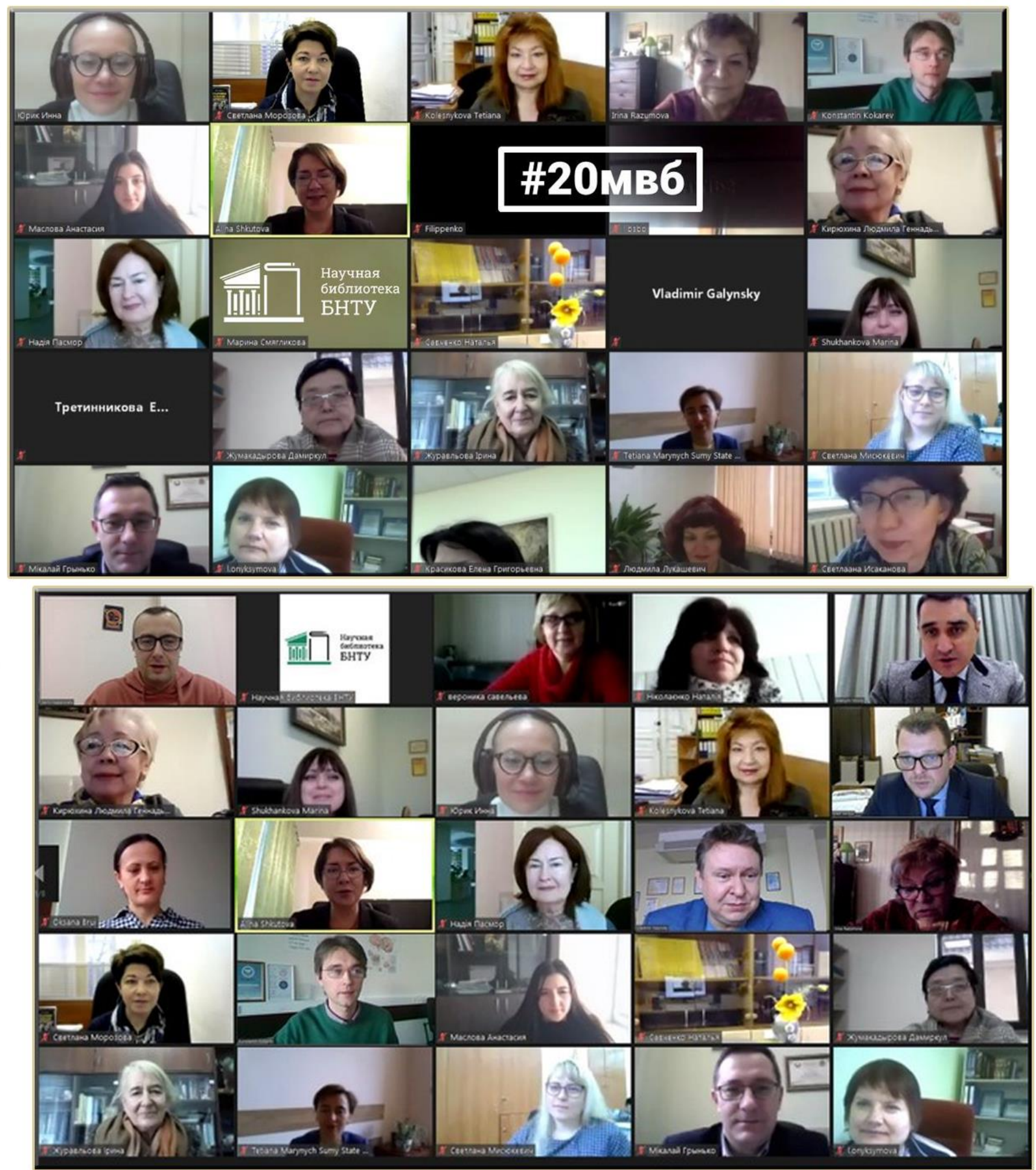

МЕЖДУНАРОДНАЯ

НАУЧНО-ПРАКТИЧЕСКАЯ КОНФЕРЕНЦИЯ

МЕНЕДЖМЕНТ

ВУЗОВСКИХ

БИБЛИОТЕК

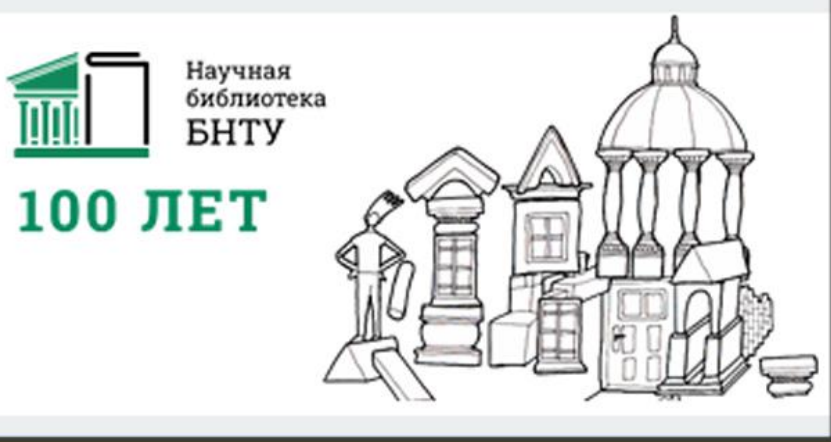

